\title{
Assessing resilience in long-term ecological data sets
}

\author{
F. Müller ${ }^{\mathrm{a}, *}$, M. Bergmann ${ }^{\mathrm{b}}$, R. Dannowski ${ }^{\mathrm{c}}$, J.W. Dippner ${ }^{\mathrm{d}}$, A. Gnauck ${ }^{\mathrm{e}}$, P. Haase ${ }^{\mathrm{f}}$, \\ Marc C. Jochimseng, P. Kasprzak ${ }^{\mathrm{h}}$, I. Kröncke ${ }^{\mathrm{i}}$, R. Kümmerlin' ${ }^{\mathrm{j}}$, M. Küster ${ }^{\mathrm{k}}$, G. Lischeid ${ }^{\mathrm{c}}$, \\ H. Meesenburgl , C. Merz ${ }^{\mathrm{c}}$, G. Millat ${ }^{\mathrm{m}}$, J. Müller ${ }^{\mathrm{n}}$, J. Padisák ${ }^{\mathrm{D}}$, C.G. Schimming ${ }^{\mathrm{p}}$, \\ H. Schubert ${ }^{\mathrm{q}}$, M. Schult ${ }^{\mathrm{k}}$, G. Selmeczy ${ }^{\mathrm{r}}$, T. Shatwell ${ }^{\mathrm{s}}$, S. Stoll ${ }^{\mathrm{f}}$, M. Schwabe $^{\mathrm{t}}$, T. Soltwedel ${ }^{\mathrm{b}}$, \\ D. Straile ${ }^{g}$, M. Theuerkauf ${ }^{\mathrm{k}}$
}

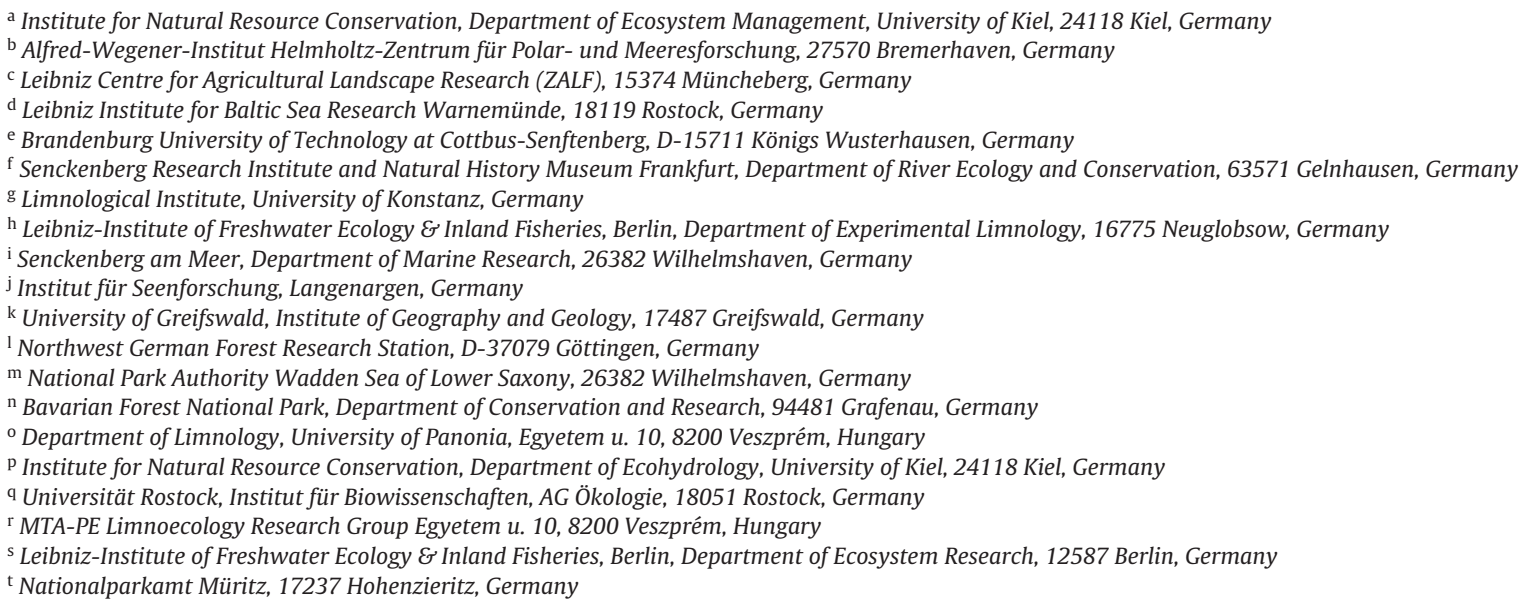

A B S T R A C T

In this paper the concept of resilience is discussed on the base of 13 case studies from the German branch of the International Long-Term Ecological Research Program. In the introduction the resilience approach is presented as one possibility to describe ecosystem dynamics. The relations with the concepts of adaptability and ecological integrity are discussed and the research questions are formulated. The focal research objectives are related to the conditions of resilient behaviour of ecosystems, the role of spatio-temporal scales, the differences between short- or long-term dynamics, the basic methodological requirements to exactly define resilience, the role of the reference state and indicators and the suitability of resilience as a management concept. The main part of the paper consists of 13 small case study descriptions, which demonstrate phase transitions and resilient dynamics of several terrestrial and aquatic ecosystems at different time scales. In the discussion, some problems arising from the interpretation of the time series are highlighted and discussed. The topics of discussion are the conceptual challenges of the resilience approach, methodological problems, the role of indicator selection, the complex interactions between different disturbances, the significance of time scales and a comparison of the case studies. The article ends with a conclusion which focuses on the demand to link resilience with adaptability, in order to support the long-term dynamics of ecosystem development.

\footnotetext{
* Corresponding author at: Institute for Natural Resource Conservation, Department of Ecosystem Management, University of Kiel, Olshausenstrasse 75, D 24118 Kiel, Germany. Tel.: +49 431880 3251; fax: +49 4318804083 .

E-mail address: fmueller@ecology.uni-kiel.de (F. Müller).
} 


\section{Introduction}

Within the international long-term ecological research program at many sites around the globe, several ecological attributes and indicators are measured and interpreted in long time series that are mostly based on the ecosystem approach. ${ }^{1}$ One of their purposes is an empirical support by providing data and knowledge to illustrate, prove or improve theoretical concepts or practical management options. In order to demonstrate such applications, the inducement of the tenth anniversary of the German LTER branch ${ }^{2}$ was used to arrange some data-based contributions around the questions "Can we contribute long-term developmental data to analyze the resilience of ecosystems?" and "How can we position resilience among other conceptions of ecosystem development?"

The ecological discussions about resilience started with Holling's fundamental paper in 1973 and have provoked a longterm career of the concept from ecological systems analysis (e.g. Gunderson and Pritchard, 2012; Walker and Salt, 2012) into social-ecological systems (e.g. Berkes and Folke, 1998), recent policy programs (European Commission, 2012), social-ecological strategies (e.g. Gunderson et al., 2012) and law (Garmestani et al., 2013). This development has been accompanied by resilience approaches in many other scientific disciplines, such as psychology, economics, sociology or technology. The result is an enormous amount of different comprehensions, vague approaches, diffuse terms and strongly utilized metaphors. Within this broad field it is advisable to concentrate, and therefore the focus of this paper is put on the relations of resilience and the dynamics of ecosystems.

These ecosystems can be understood as nonlinear largescale and complex, dynamic, thermodynamically open systems (Jorgensen, 1992). They are characterized by features of integrity, health, complexity, multidimensional stability, buffer and storage capacity as well as by special dynamic characteristics such as observability, controllability and information processing and storage (Gnauck et al., 2010). Structures in ecosystems are qualified by physical, chemical and biological ecosystem elements and their spatio-temporal patterns (Pahl-Wostl, 1997). Functions are related to transfers and circulations of matter as well as to energy depletion, to interrelations between ecosystem elements and interrelations between an ecosystem and its environment. Ecosystems furthermore may be characterized by their high dimensionality referred to the number of static and dynamic elements and their behaviour, by their uncertainty of interrelations with a restricted degree of mathematical calculability. Therefore, ecosystems should be considered as stochastically disturbed dynamic systems (Straškraba and Gnauck, 1985).

Analyzing key variables of ecosystem dynamics, De Angelis (1980), Pimm (1984), Pimm et al. (1991) as well as Grimm et al. (1992) and Grimm and Wissel (1997) have discussed different concepts of ecological stability. Especially, Grimm and Wissel (1997) considered 163 definitions of 70 different stability concepts. At least, they found three different stability notions: Constancy, ${ }^{3}$ resilience, and persistence. They understand stability as a multilayered concept including the concepts of resistance or elasticity (following Schaefer and Tischler, 1983). From a mathematical viewpoint, Pahl-Wostl (2000) stated that four concepts are related to stability: resilience, persistence, ${ }^{4}$ resistance, ${ }^{5}$ and variability. ${ }^{6}$

\footnotetext{
${ }^{1}$ http://www.ilternet.edu/.

2 http://www.ufz.de/lter-d/.

${ }^{3}$ Constancy: the system stays essentially unchanged after a pertubation.

4 Persistence: demonstrates how long a variable lasts before it is changed into a new value.

Resistance: measures the degree to which a variable is changed, following a pertubation.

${ }^{6}$ Variability: the degree to which a variable varies over time.
}

The international Resilience Alliance ${ }^{7}$ (Folke, 2006; Janssen et al., 2006) has strongly and successfully supported the concept of resilience in combination with viability theory (Martin, 2004; Martin et al., 2011) within the context of socio-economy and ecology. The network focussed its interest on the management of agent-based complex systems and their functioning. Therefore, Grimm and Calabrese (2011) distinguished analytical (including constancy, resistance and engineering resilience of single state variables and their dynamics) and synthetic aspects of resilience (covering persistence and ecological resilience). We will discuss the first of these approaches in the following.

In this paper, resilience is generally understood as a dynamic indicator of ecosystem behaviour after the occurrence of a disturbance. Fig. 1 is demonstrating the processes following a disturbance at a small time scale: at the left side, a selected indicator variable is developing within a relatively invariable basin of attraction of the ecosystem. At time $d_{1}$ a pertubation ${ }^{8}$ is happening which does not exceed the resistance of the system, the values easily return to the basin of attraction. At the moment $d_{2}$ the system experiences a disturbance ${ }^{9}$ with a certain duration and abruptness, which changes the value of the observed state variable from A down to B. In the case $D_{2}$, the variable does not recover and the system is moving towards a new attractor state as a consequence of a regime shift. ${ }^{10}$ The second trajectory $C$ leads to increasing values of the observed variable, reaching the old attractor's characteristics again. In this case we can talk about resilience which in general is the ability of an ecosystem to return to the original attractor state after a disturbance. Resilience can be indicated by the return time of the recovery dynamics or by the magnitude of the disturbance (F).

Fig. 2 takes into consideration a much longer time interval in a modified version of the adaptive cycle (see e.g. Gundersson and Holling, 2002; Burkhard et al., 2011). Starting in a pioneer stage, an ecological succession proceeds slowly provoking a steady increase of ecosystem variables, like exergy storage which shows an interlinked growth with the connectedness of the system. During this period complexification ${ }^{11}$ is a dominating developmental process. At this long-term viewpoint, resilience is related to the short time intervals, while the system is remaining in the recent attractor basin. This value range is not constant, but changing over the successional period, whereby several indicators are increasing in an orientor manner (Joergensen et al., 2007). Such behaviour is called adaptability, the ability of an ecosystem to develop in a complexifying succession, whereby certain indicator values (orientors) are steadily increasing (see Müller et al., 2010a,b).

Already these two viewpoints show that the term resilience can be used in several different contexts. To demonstrate the broad range of these comprehensions, Table 1 is summarizing different definitions of resilience. It is visible that there are many different comprehensions and that within the table a certain development is documented from "pure" ecological aspects to socio-ecological systems. Also the role of change is valued in different categories: while in the first, initial definition the return to the preceding attractor

\footnotetext{
7 www.resalliance.org.

8 Pertubation: Any change of external parameters, including those inputs which do not change the behaviour/state of the investigated system.

9 Disturbance: A pertubation which modifies the state of the system or "any process that effects ecosystem, community, or population structure and/or individuals within a population directly or indirectly via changes to the biophysical conditions" (Standish et al., 2014).

10 Regime shift: Development of an ecosystem after a disturbance which leads to new steady states outside the attractor domain of the original system. The domain of attraction can be characterized by the long-term average values and their variability. 11 Complexification: During the undisturbed development of ecosystems, in many cases the complexity steadily increases, to be indicated e.g. by biodiversity, heterogeneity, cycling, storage rise, flow articulation, symbiosis, and other characteristics (orientors).
} 


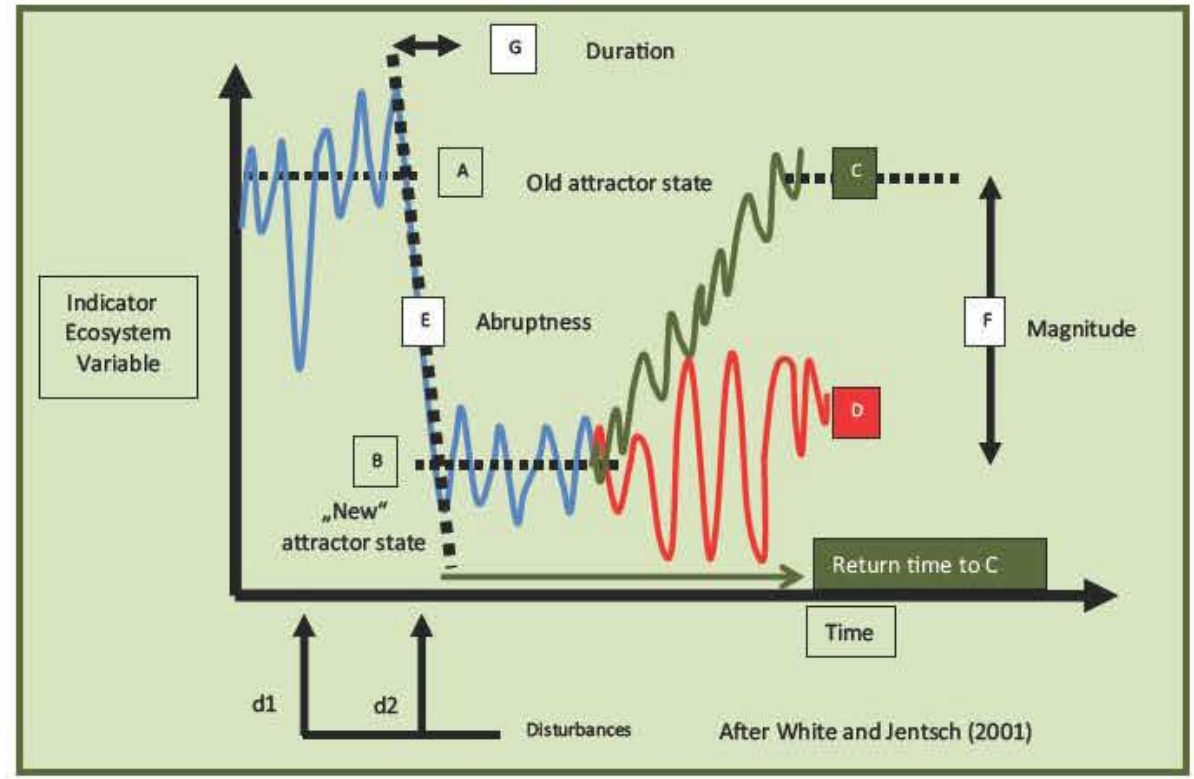

After White and Jentsch (2001).

Fig. 1. Conceptual scheme on the potential behaviour of ecosystem variables after disturbances.

domain is used as a target function, in the younger comprehensions, e.g. in the 10th example in Table 1, the ability for development functions as a goal of resilience. We will come back to these distinctions throughout the discussion chapter of this paper.

As the comprehension of resilience is rather diverse, the quantification and indication also can be characterized by a high variability of approaches. There are two mainstreams, related to the terms "engineering resilience" and "ecological resilience". While the first one is assessed on the basis of the duration a system needs to return to the state it had before the disturbance (return time of focal variables after Pimm, 1984), the ecological resilience shall be measured by the magnitude of disturbance that can be absorbed before the system changes its structure, functions and controls (Gundersson and Holling, 2002; Peterson, 2002). We will see that both approaches are related to interesting methodological challenges. Other proposals for resilience indication are related to the trend of an ecosystem to maintain ecosystem integrity when subject to a disturbance (Ludwig et al., 1997; Redman et al., 2000) or to the degree to which the system is capable of self-organization (Harrison et al., 2004). We will use the case-studies to see if these proposals are realistic from an empirical point-of-view.

As our case studies are generally linked with long-term approaches, we can build upon some papers in the literature on using long-term approaches to characterize the long-lasting development of resilience. For instance, Mirtl et al. (2013), Parr et al. (2003) and Redman and Kinzig (2003) are investigating these items from general and conceptual viewpoints, while other authors are applying resilience approaches to specific ecosystem types, such as

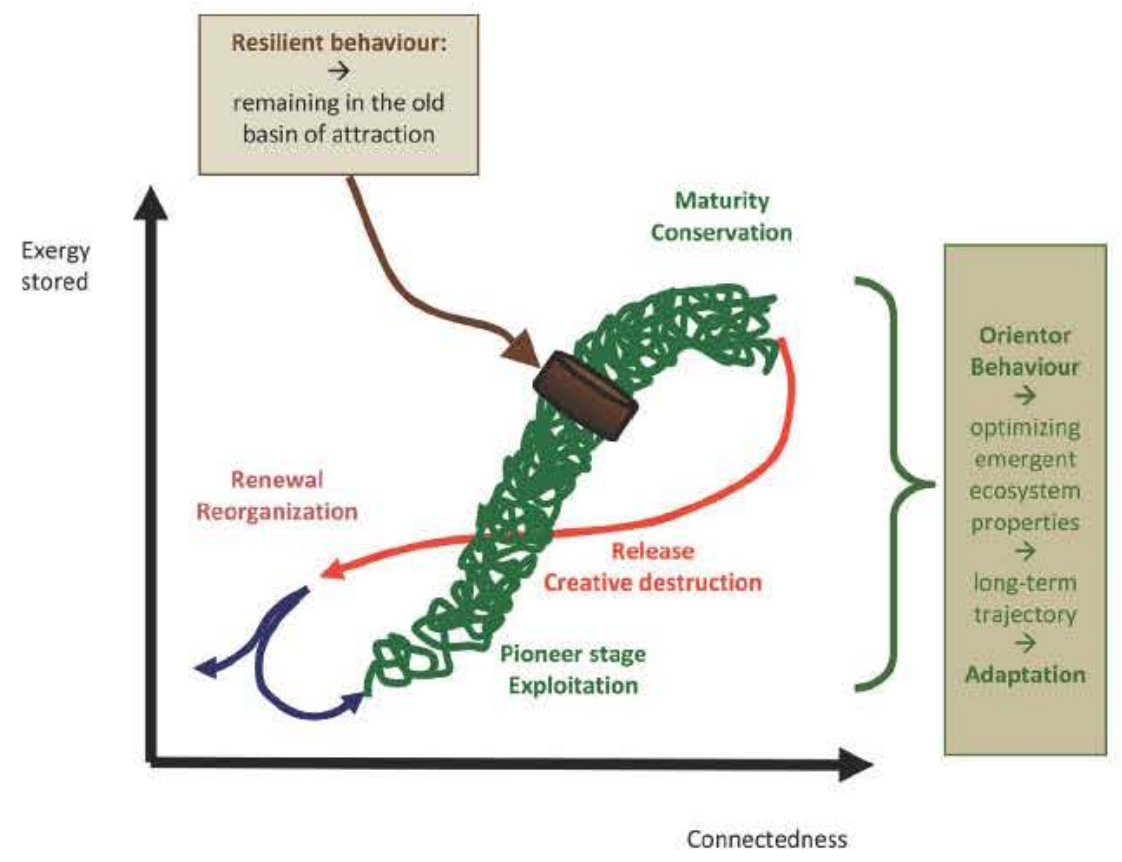

Fig. 2. Resilience and adaptability during ecosystem development. 
Table 1

Modifications in the understandings of resilience at different levels of integration, after Brand (2005).

\begin{tabular}{|c|c|c|c|}
\hline \multicolumn{2}{|c|}{ Level of comprehension } & \multirow{2}{*}{$\begin{array}{l}\text { Definition } \\
\text { Measure of the persistence of systems and of their ability to absorb change and disturbance } \\
\text { and still maintain the same relationships between populations or state variables }\end{array}$} & \multirow{2}{*}{$\begin{array}{l}\text { Source } \\
\text { Holling (1973) }\end{array}$} \\
\hline 1 & Original definition & & \\
\hline 2 & Disturbance-focused & $\begin{array}{l}\text { Magnitude of disturbance that can be absorbed before the system changes its structure by } \\
\text { changing the variables and processes that control behaviour }\end{array}$ & $\begin{array}{l}\text { Holling and } \\
\text { Gunderson } \\
\text { (2002) }\end{array}$ \\
\hline 3 & Ecological-functional & $\begin{array}{l}\text { Capacity of a system to absorb disturbance and reorganize while undergoing change so as to } \\
\text { still retain essentially the same function, structure, identity and feed backs }\end{array}$ & $\begin{array}{l}\text { Gundersson } \\
\text { and Holling } \\
(2002)\end{array}$ \\
\hline 4 & Ecological-systemic & $\begin{array}{l}\text { (1) Capacity of a system to undergo disturbance and maintain its functions and controls, to be } \\
\text { measured by the magnitude of disturbance that the system can tolerate and still persist } \\
\text { (2) Ability of the system to resist disturbance and the rate at which it returns to the } \\
\text { pre-disturbance steady state (engineering resilience after Pimm (1984) }\end{array}$ & $\begin{array}{l}\text { Carpenter et al. } \\
(2001)\end{array}$ \\
\hline 5 & Ecological-quantitative & $\begin{array}{l}\text { (1) The amount of change (external pressure) the system can sustain without changing the } \\
\text { domain of attraction } \\
\text { (2) The degree to which the system is capable of self-organization } \\
\text { (3) The degree to which the system can build capacity to learn and adapt }\end{array}$ & $\begin{array}{l}\text { Walker et al. } \\
(2002)\end{array}$ \\
\hline 6 & $\begin{array}{l}\text { Social-ecological: } \\
\text { ecosystem services }\end{array}$ & $\begin{array}{l}\text { The underlying capacity of an ecosystem to maintain ecosystem services in the face of a } \\
\text { fluctuating environment and human pertubations. }\end{array}$ & $\begin{array}{l}\text { Deutsch et al. } \\
\text { (2003) }\end{array}$ \\
\hline 7 & $\begin{array}{l}\text { Social-ecological: } \\
\text { societal progress }\end{array}$ & $\begin{array}{l}\text { The capacity of ecosystems to sustain societal development and progress with essential } \\
\text { ecosystem services }\end{array}$ & $\begin{array}{l}\text { Folke et al. } \\
(2003)\end{array}$ \\
\hline 8 & $\begin{array}{l}\text { Social-ecological: } \\
\text { functions and services }\end{array}$ & $\begin{array}{l}\text { Resilience refers to the magnitude of change or disturbance that a system can experience } \\
\text { without shifting into an alternate state that has different structural and functional properties } \\
\text { and supplies different bundles of ecosystem services }\end{array}$ & $\begin{array}{l}\text { Resilience } \\
\text { Alliance (2010) }\end{array}$ \\
\hline 9 & Explicitly normative & Maintenance of natural capital & Ott (2001) \\
\hline 10 & Dynamic: development & $\begin{array}{l}\text { Resilience is the capacity of a system, be it an individual, a forest, a city or an economy, to deal } \\
\text { with change and continue to develop. It is about how humans and nature can use shocks and } \\
\text { disturbances like a financial crisis or climate change to spur renewal and innovative thinking. }\end{array}$ & $\begin{array}{l}\text { Stockholm } \\
\text { Resilience } \\
\text { Center (2015) }\end{array}$ \\
\hline 11 & $\begin{array}{l}\text { Political: } \\
\text { transformation }\end{array}$ & $\begin{array}{l}\text { Resilient systems in agricultural landscapes are able to recover their fundamental structure } \\
\text { and functionality in the face of change or to transform into new regimes where this has } \\
\text { desirable environmental and social outcomes }\end{array}$ & CGIAR (2014) \\
\hline
\end{tabular}

forests (e.g. Sanz et al., 2013; Chapin et al., 2010), agro-ecosystems (e.g. Cabell and Oelofse, 2012), urban systems (Redman et al., 2004; Evans, 2011), landscapes (e.g. Cumming, 2011a; Zurlini et al., 2014), coastal areas (e.g. Newton, 2011), oceans (e.g. Mazzocchi et al., 2012; Pugnetti et al., 2013, or Adam et al., 2011), freshwater ecosystems (e.g. Willis et al., 2010; Jackson and Fuereder, 2006; Shade et al., 2012), or arctic ecosystems (e.g. Chapin et al., 2004; Prowse et al., 2006). Further elaborations on long-term resilience have e.g. been carried out by Symstad et al. (2003) with respect to biodiversity dynamics and Vihervaara et al. (2013) to investigate the consequences of climate change.

The contribution of long-term ecological research to the knowledge about disturbance dynamics has been review by Turner et al. (2003). These authors emphasize that especially long-term research can detect, monitor, and understand unanticipated events, it is capable of determining the of scale and heterogeneity, show neglected dynamics of slow variables and include rare events (fire, flood, drought, hurricanes, insect pests, exotic species, land use, climate) which are not detectable at short time-scales. As in many cases spatio-temporal hierarchies are connected with a regulatory domination by constraints from slow, long-term processes, longterm research can be extremely helpful in better understanding the control structures of ecosystems. Therefore, we are asking if long-term research is also suitable in investigating the resilience of ecological systems.

To follow this objective, four focal questions will be posed:

- Under which conditions can we find resilient behaviour of ecosystems in the investigated long-term data sets?

- Which is the role of spatio-temporal scales? Is resilience restricted to ecosystem dynamics within short-term dynamics or does it also appear at longer time scales?

- Which are the methodological requirements to exactly define resilience? Which is the role of the reference state and which influences can be assigned to the selected indicators?

- Is resilience a suitable management concept with respect to longterm ecological dynamics? In which cases should it be used as a management guideline and in which cases should it not be applied?

Due to the interdisciplinary concept, the restricted space and the central role of case studies, this article does not follow the traditional length and structure of scientific publications. There is no materials and methods section; either some characteristics are given within the single case study description or there is a reference to original papers which provide much more detailed information on the methodology. The main part of the article is dedicated to the case study reports. The case studies are arranged in a sequence of temporal scales (from long term to short term observations), mainly referring to the duration of the time series. Each case study report includes an introductory paragraph, where the described processes and problems are explained and the relevance for the objectives of the paper is discussed. Furthermore initial information is provided concerning the study site as an LTER research area, the applied spatial and temporal scales, the focal investigated disturbances, the applied indicators and their indicanda, the respective reference points and the method of quantification. After the case study descriptions the results are summarized and discussed and some concluding remarks will be given.

\section{Case studies}

The set of case studies contains 5 terrestrial sites, 4 marine seascapes and 3 freshwater systems. With the exception of "Hausgarten", situated in the Fram Strait of the Northern Atlantic Ocean, all sites are positioned in German land- and seascapes (see Fig. 3). The northern sites (Bornhöved Lakes, Serrahn, Uckermark) can be characterized by relatively flat areas which have been mainly created by the Pleistocene glaciations of Northern Europe. Lange Bramke, Bavarian Forest and Hesse are situated in the low mountain ranges while Lake Constance is located directly at the edge of the Alps. In contrast, the sites Wadden Sea and Norderney are parts of the North Sea and the Darß-Zingst-Bodden Chain is a lagoon system at the Baltic Sea. 


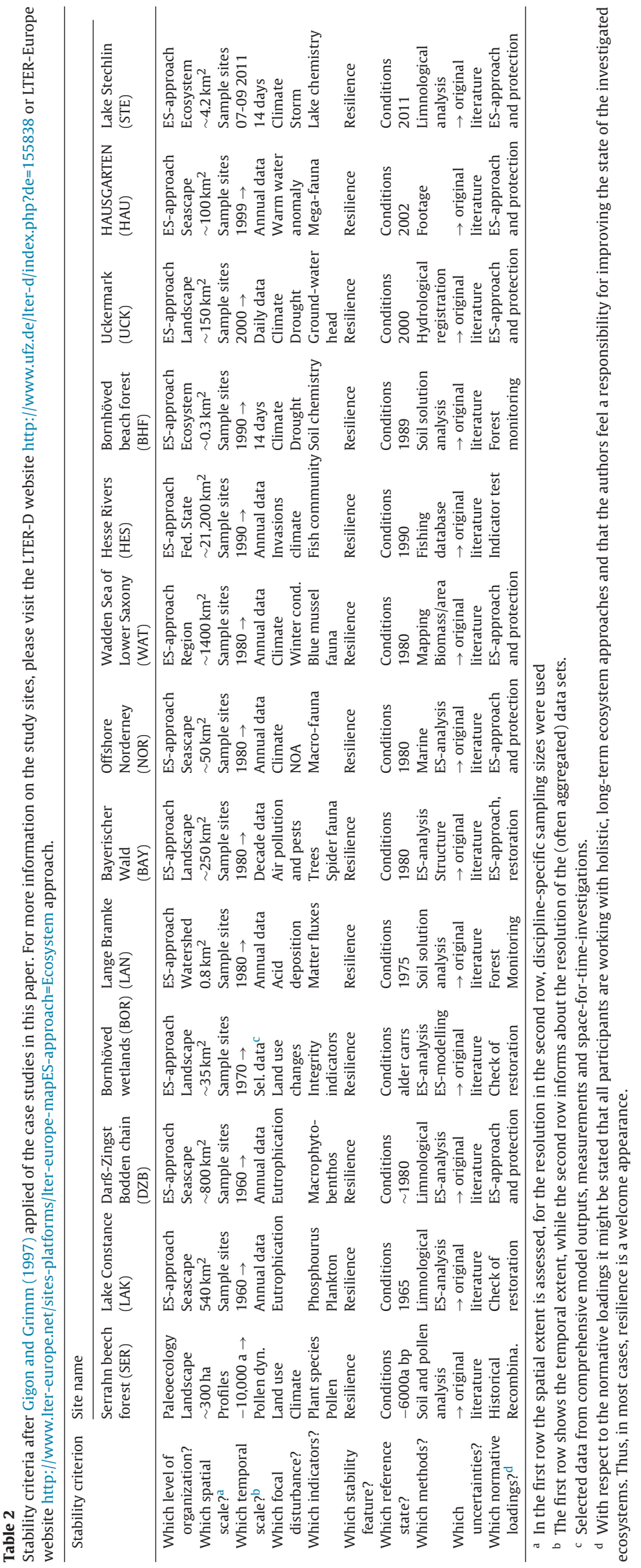




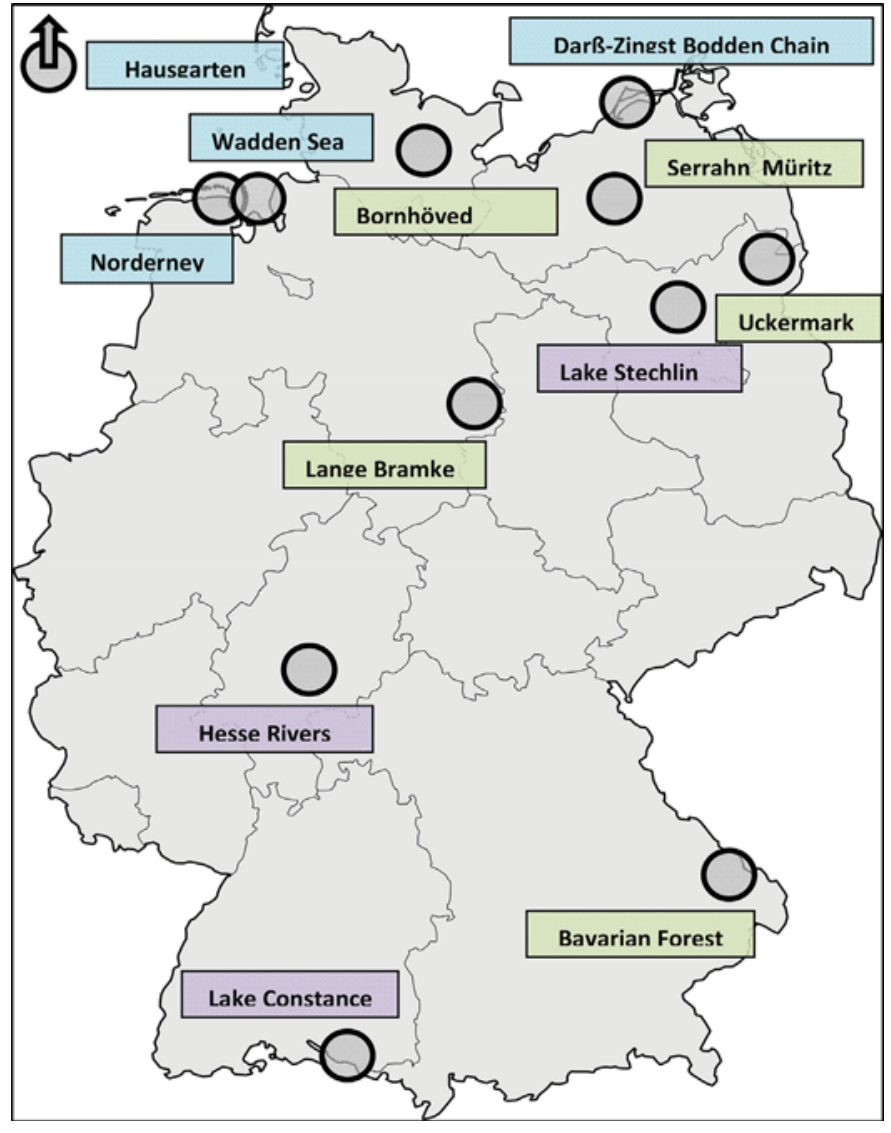

Fig. 3. Geographical positions of the case study areas.

The resilience related characteristics of the sites are listed in Table 2 which also provides information on the applied methodologies, the focal scales, the investigated disturbances and their special features. The table also provides information on the basic requirements for stability investigations as formulated by Gigon and Grimm (1997).

Resilience of forest ecosystems - an example from an ancient beech forest of the UNESCO World Natural Heritage site Serrahn Müritz National Park (SER)

(M. Theuerkauf, M. Küster, M. Schult, M. Schwabe)

National parks are places to enjoy, experience and learn about nature. An appropriate management of National Parks requires a profound understanding of ecosystem dynamics over long time scales. However, such long term perspective is usually limited due to the lack of long time series of observations. In Müritz National Park, for example, time series of nature observations typically cover some months or years. Only 4 series cover up to 25 years. The longest time series of forest observations available from the region cover some 150 years - which is still rather short to study the slow response of forest ecosystems following disturbances.

In Müritz National Park thus palaeoecological research is applied to extend time series into the past. To study ecosystem change in the greatest possible detail, palaeoecological studies in the park cover both vegetation and the abiotic environment, including sediments and soils (e.g., Kaiser et al., 2002; Küster et al., 2012, 2014). Palaeoecological research started in the area within the framework of an extended ecosystem research project (Scamoni, 1963). To explore the relationship between landscape patterns and vegetation development, Müller (1962) produced 23 pollen diagrams from a 10 by $10 \mathrm{~km}$ landscape with large contrasts in soils and relief conditions. This strong focus on ecological questions has certainly been a unique approach in palaeoecology. However, due to low temporal resolution (mostly $>200$ years) and the lack of independent dating Müller (1962) was limitedly able to address questions on e.g. short lived vegetation response to e.g. human disturbance. More recent studies focus on the Late Holocene landscape history, including the history of the ancient beech forests of Serrahn, which are part of the UNESCO World Natural Heritage. The two main questions of this study are: (i) When did beech forest establish in the region? (ii) How did beech forests respond to human disturbances?

The cold climate of the last ice age resulted in a largely open, treeless landscape. With the onset of the Holocene warm period 11,700 years ago, forests again expanded and around 10,000 years ago, dense broad leaved (with e.g. alder, elm, hazel, lime and oak) and coniferous forests (dominated by pine) had established. Beech was initially absent from these forests. Pollen data suggest that first (Fig. 4), small beech populations established some 6000 years ago. Only about 3000 years ago beech started to expand and to form widespread forests. It is still debated why beech expanded so late in northern Germany (and Scandinavia). Ralska-Jasiewiczowa et al. (2003) suggest that the late expansion of beech has been triggered by a climatic shift towards cooler and wetter conditions. So far there is poor evidence of such climatic shift, however. An alternative hypothesis is based on the observation that the expansion of beech follows periods of intense human land use (e.g. Spangenberg, 2008; Bradley et al., 2013). The hypothesis suggests that the expansion of beech has been aided by human activity, i.e. beech only expanded after the pristine forests had been opened up. It remains unexplained, why beech, which is well able to expand in dense shade, depended on forest clearance to expand. Future research in the area thus needs to focus on the exact pattern and timing of beech expansion to better understand its late expansion.

In the Müritz region, agricultural land use started some 6000 years ago. Human activity since then can be characterized by repeated changes between high and low land use intensities. Küster (2014) observed eight periods of increased soil erosion, which well correspond to periods of more open vegetation, i.e. more intense land use, recorded in the pollen data (Fig. 4). While beech initially obviously benefitted from forest opening during the Bronze age/Iron age period, possibly more the $50 \%$ of beech forests in the Müritz region vanished during the Slavonic settlement periods and the Medieval. In between these periods, forest recovery starting with birch (Betula pubescens/B. pendula), followed by hornbeam (Carpinus betulus) and then beech has been observed. These periods of low land use intensity are too short, however, for a full recovery of beech forests in the region.

Also the World heritage site of Serrahn with its ancient beech forests has been used for farming in former times. A study of sediments and soils from Serrahn revealed periods of intense land use resulting in soil erosion, e.g. during the Slavonic period about 1000 years ago (Fig. 4). During these periods pollen data clearly indicate that beech went locally extinct but recovered after abandonment of the area (Küster, 2014).

Summarizing, it can be stated that palaeoecology is a suitable tool to prolong time series and thus to study long term dynamics of forest ecosystems. Palaeoecological studies have revealed that beech only expanded late in the Holocene. Evidence suggests that the pristine forests of Northern Germany and Southern Scandinavia have been "stable" ecosystems, which were resilient against disturbance by beech as a new forest element. Only additional disturbances due to human activity allowed beech to expand. Why the expansion of beech, which is well able to establish in the shade, was limited, is not yet understood. To understand the causes of its late 


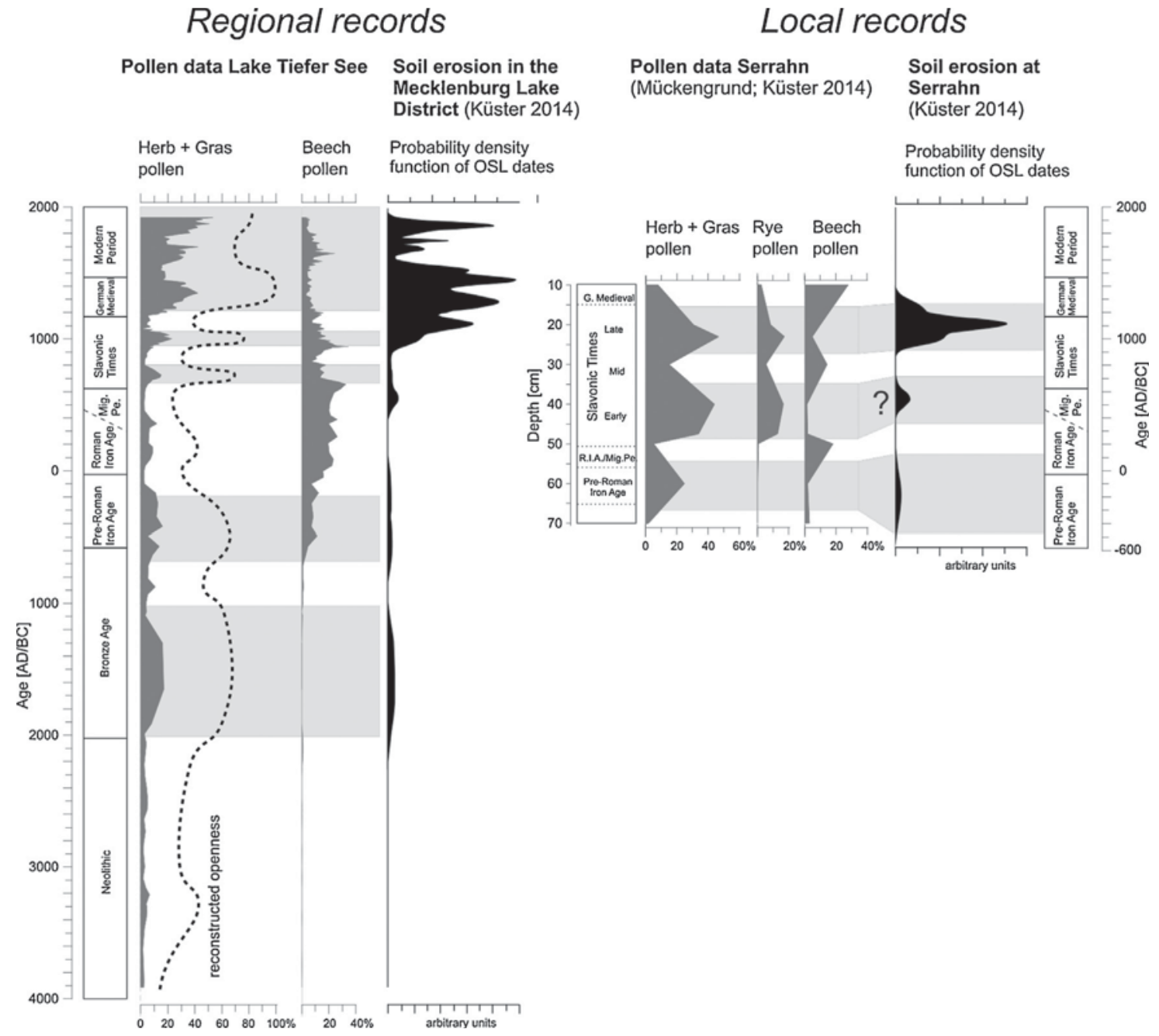

Fig. 4. The history of beech in the Müritz area (left) and in the area of ancient beech forests near the World Heritage site Serrahn (right) as recorded in proxies of vegetation and soil erosion (OSL: "optically stimulated luminescence" datings). Pollen data from Lake Tiefer See show recurrent changes in pollen deposition of herbs and grasses, which indicate changes in landscape openness over the past 6000 years. A tentative reconstruction of past openness (dashed line) indicates that during several periods more than $50 \%$ of the landscape may have been deforested. Widespread deforestation triggered soil erosion (black curves), which is recognized at both the regional and local scale. Beech expanded in the area started during the Pre-Roman Iron Age. It reached maximum cover during the migration period with less intense land use, but again largely declined the intense land use in the Slavonic period and since the Medieval.

expansion, future studies need to explore more details of beech expansion by studying well dated sites in high resolution. Since beech established nearly 3000 years ago, it is a highly competitive forest tree that re-expands after recurrent periods of intense land use. However, regeneration takes comparatively long, so that recovery of beech is not completed in shorter regeneration periods. Furthermore, this case study can demonstrate that during long time periods there are high probabilities of external changes, leading to a series of non-resilient behaviour and developmental dynamics into new, adapted ecosystem states.

Response of a deep lake to eutrophication and oligotrophication (LAK)

(D. Straile, M.C. Jochimsen, R. Kümmerlin)

Cultural eutrophication is one of the most severe problems for the water quality of lakes (Schindler and Vallentyne, 2008). Eutrophication may result in hypolimnetic anoxia (e.g. Barbieri and Simona, 2001), extinction of species (e.g. Vonlanthen et al., 2012) and blooms of toxic cyanobacteria (e.g. Taranu et al., 2015) thereby strongly affecting lake ecosystem services. In many European lakes eutrophication accelerated after 1945 (Keatley et al., 2011; Taranu et al., 2015), and often prompted countermeasures, e.g. the ban of phosphorus-containing detergents and/or the establishment of sewage plants. As a result of successful phosphorus elimination in the catchments, phosphorus concentrations decreased again in many European lakes (Jeppesen et al., 2005).

This typical history of disturbance and recovery from phosphorus pollution is also shared by Lake Constance, a large and deep per-alpine lake bordering Germany, Switzerland, and Austria. Lake Constance experienced severe eutrophication in the 2 nd half of the 20th century (Fig. 5a) with total phosphorus concentrations during winter mixing $\left(\mathrm{TP}_{\mathrm{MIX}}\right)$ increasing more than one order of magnitude within 30 years (from $7 \mu \mathrm{g} / \mathrm{L}$ in 1952 to $87 \mu \mathrm{g} / \mathrm{L}$ in 1981) and an equally rapid decline pf TP concentrations thereafter (within 27 years back from $81 \mu \mathrm{g} / \mathrm{L}$ to $8 \mu \mathrm{g} / \mathrm{L}$ in 2007), which makes the lake ideally suited to study ecosystem resilience and reversibility to disturbance.

The response of total phytoplankton biomass and the biomass of different phytoplankton groups has been investigated for the period 1965-2007 (Jochimsen et al., 2013). During this period total phosphorus concentrations during winter mixing ( $\mathrm{TP}_{\mathrm{MIX}}$ ) increased from $36 \mu \mathrm{g} / \mathrm{L}$ towards $87 \mu \mathrm{g} / \mathrm{L}$, and declined thereafter to $8 \mu \mathrm{g} / \mathrm{L}$ 


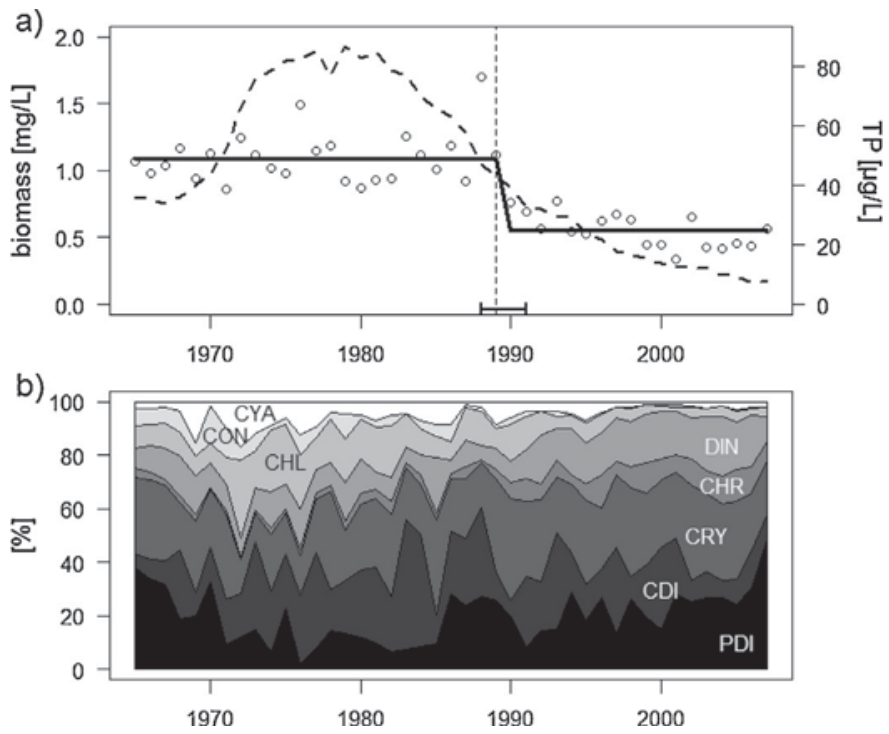

Fig. 5. (a) Development of total phosphorus concentrations during winter mixis and of phytoplankton biomass (annual average) during 1965-2007. The OLS cusum test (Zeileis et al., 2003) suggests 1989 (95\% confidence intervals: 1988-1991) as the timing of a regime shift, (b) community composition of annual average phytoplankton biomass during the study period.

in 2007 thereby passing the $\mathrm{TP}_{\mathrm{MIX}}$ level of 1965 in 1990. Despite a roughly 10 -fold change in TP $\mathrm{MIX}$ concentrations annual average phytoplankton biomass only varied by a factor of 2 (Fig. 5a). Furthermore, annual average biomass was rather constant during the first 25 years of the study period (thereafter P1) - despite roughly 2-fold variability of $\mathrm{TP}_{\mathrm{MIX}}$ concentrations - and during the last 15 years of the study period (thereafter P2), during which $\mathrm{TP}_{\mathrm{MIX}}$ concentrations declined approximately 4 -fold. Hence, phytoplankton community showed two periods during which total biomass was resilient with respect to large changes in total phosphorous concentrations. Only after TP concentrations dropped below a specific TP concentration, phytoplankton biomass declined rapidly to approximately $50 \%$ of the biomass reached on average during P1.

Biomass stability during P1 was associated with compensatory dynamics of the different algal groups (Jochimsen et al., 2013), i.e. increases of some groups with eutrophication (centric diatoms, chlorophytes, conjugates) from 1965 towards the 1970s/early 80s were offset by the declines of other groups (pennate diatoms, chrysophytes) (Fig. 5b). Furthermore, community composition was reversible during the shift from mesotrophic to eutrophic conditions and vice versa (from approximately $35 \mu \mathrm{g} / \mathrm{L}$ towards $87 \mu \mathrm{g} / \mathrm{L}$ and back) at this level of taxonomic aggregation (Fig. 6). Non-metric multidimensional scaling (NMDS) ordination shows that the study years can be nicely separated by phosphorus concentrations. Furthermore, years with $\mathrm{TP}_{\mathrm{MIX}}$ between 20 and $70 \mu \mathrm{g} / \mathrm{L}$ before and after maximum $\mathrm{TP}_{\mathrm{MIX}}$ (i.e. before 1972 and after 1983) are located nearby, i.e., community composition in the late 1960s was similar to community composition in 1989, 1990 (Fig. 6), when TP ${ }_{\text {MIX }}$ has decreased to levels typical for the late 1960s (Fig. 5a).

Compensatory dynamics were only observed during P1 and not during P2 suggesting that only during P1, but not during P2, they might have contributed to biomass stability (Jochimsen et al., 2013). Biomass stability during P2 might at least be partially due to a reduction of grazing pressure. A data based modelling study has shown that during the spring bloom, control of phytoplankton population growth rates did strongly change from 1980 towards 2007 (Kerimoglu et al., 2013). While during the early 1980s phytoplankton growth during the spring bloom was hardy phosphorus limited, phosphorous limitation was the most important

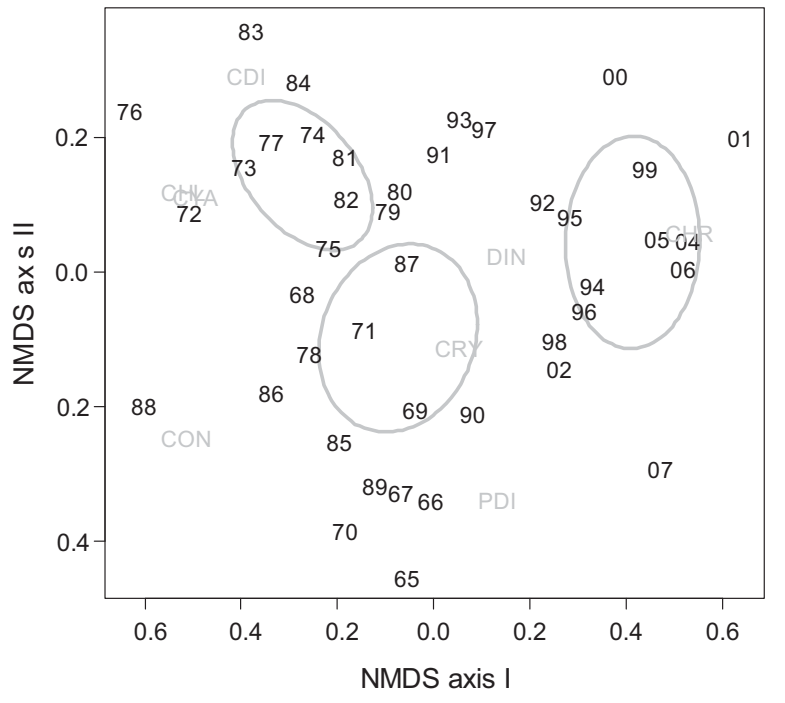

Fig. 6. NMDS ordination of the main algal groups during 1965-2007. The three ellipses represent $99 \%$ confidence intervals around the centroids of three groups based on TP MIX levels: TP $_{\text {MIX }}<20 \mu \mathrm{g} / \mathrm{L}$ (right ellipse, 1997-2002), $>70 \mu \mathrm{g} / \mathrm{L}$ (left ellipse, 1972-1983), and TP $\mathrm{MIX}_{\mathrm{X}}$ between 20 and $70 \mu \mathrm{g} / \mathrm{L}(1965-1973$ and 1984-1996, centric ellipse).

factor reducing phytoplankton growth rates during the spring blooms of recent years. In contrast, spring phytoplankton control by microzooplankton (ciliates) and mesozooplankton (Daphnia) grazers strongly declined from 1980 to 2007. Likewise, herbivory during summer was further reduced by the decline of zooplankton abundances (unpublished data). The decline of herbivory was presumably further enhanced by changes in zooplankton community composition, e.g. a larger decline of non-migrating Daphnia galeata relative to migrating Daphnia longispina (Straile, 2015), because $D$. galeata contributes to phytoplankton losses throughout day and night, whereas migrating $D$. longispina feeds on epilimnetic phytoplankton only during night-time. Possibly, the overall decline of herbivore control contributed to the stability of annual average phytoplankton biomass during P2 and thus to the resilience of phytoplankton biomass to a further decline of phosphorus concentrations.

The response of phytoplankton to eutrophication and oligotrophication in Lake Constance exhibits various aspects of resilient behaviour at two levels of ecological organization. At the level of total biomass, phytoplankton was resilient to changes in nutrient availability during two time periods with striking changes in TP concentrations. Unfortunately, the time series does not encompass the period of phytoplankton increase prior to 1965 and thus it is not possible to analyze whether total biomass trajectories were reversible. In contrast to total biomass, community composition was not resilient to changing phosphorus concentrations during the two periods of biomass stability. Rather, community composition was tightly linked to total phosphorus concentrations, resulting in resilient community dynamics, i.e. reversibility of community composition with declining phosphorus concentrations.

Macrophytobenthos dynamics in a shallow brackish lagoon of the German Baltic Sea coast (DZB)

(H. Schubert)

Brackish conditions have been shown to reduce the number of macrozoobenthos (Remane, 1934) as well as macrophytobenthos species (Schubert et al., 2011), restricting the realization potential 


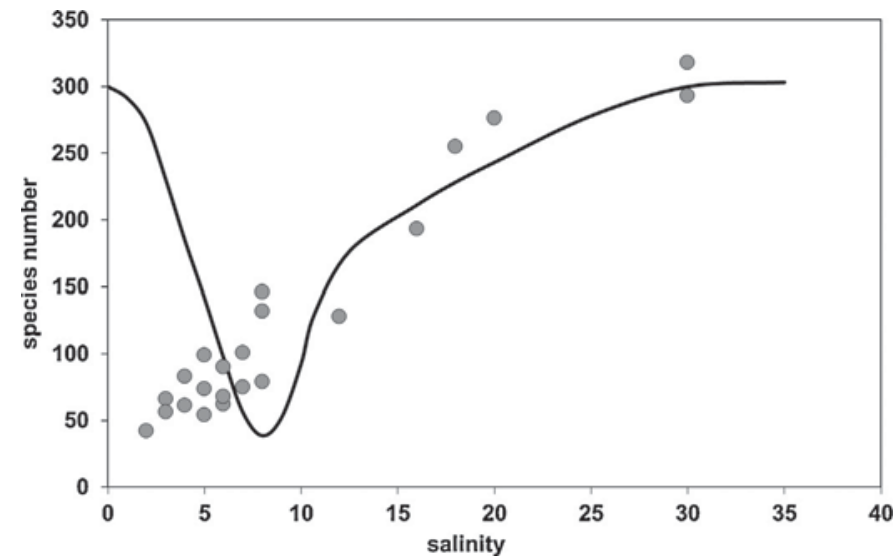

Fig. 7. Salinity dependency of species diversity: The figure shows the relation of species numbers versus salinity for makrozoobenthos (line) and makrophytobenthos (dots) as observed in the Baltic Sea by Remane (1958, makrozoobenthos) and Nielsen et al. (1995, makrophytobenthos).

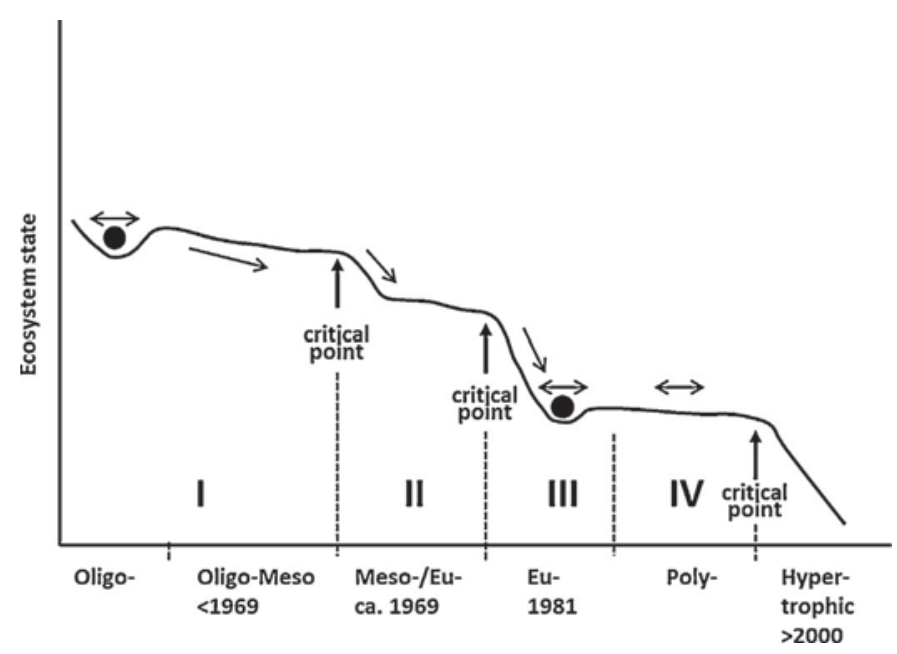

Fig. 8. Conceptual eutrophication model for the Darss-Zingst-Bodden after Schiewer (1994).

for succession drastically (Fig. 7). If disturbed by anthropogenic impacts as, e.g. eutrophication, brackish systems are thought to exhibit pronounced changes in species occurrences, expressed in stand density and depth distribution, rather than species composition. The reason for this is seen in the reduced interspecific competition, because many marine species reach their salinity limit under brackish conditions. The reduced species inventory left is composed of organisms able to thrive and reproduce under brackish conditions, but still being far from their optimum, thus intraspecific competition is rather weak.

The LTER-site in focus here, the Darss-Zingst-Bodden-Chain (Fig. 8), is one of the few examples where macrophyte communities of a brackish water body have been followed for several decades by repetitive sampling over a period of increasing as well as decreasing eutrophication, driving the systems from a meso-eutrophic state to hypertrophic and back to eutrophic conditions (Schumann et al., 2009).

The first detailed surveys, performed in the late 1930s, in principle showed the same species inventory as all later surveys; just one species, Chara tomentosa, could not be found during the period of heavy eutrophication. With increasing nutrient load between 1960 and 1990 the following characteristic changes were observed:
- shift in community structure from macroalgae (Characeae) dominancy to dominancy of phanerogams, the latter increasing in occurrence, but not fully replacing the loss of macroalgae biomass and therefore

- reduction of macrophyte-vegetated areas of the system, due to both:

- reduced depth limit of macrophyte communities and

o reduced biomass per area in the still vegetated depth zones.

A sudden decrease in nutrient load occurred in 1989, most probably due to a shift in the precipitation regime of the catchment area and stabilized by changes in agriculture practices initiated by the political change in 1990. The main result was a reduction in nutrient load, believed to restore the macrophyte communities in case that bistability of the system will not occur.

Such bistability (Scheffer, 1998) has been demonstrated for several limnetic systems. Very briefly, bistability is the result of a two-mode self-stabilization by means of biotic interactions. Under high-nutrient load conditions excessive phytoplankton growth suppresses macrophytes by shading. Macrophyte stands provide shelter areas for zooplankton, where they can hide at daytime, so losses by fish grazing are reduced, allowing efficient control of phytoplankton by zooplankton grazing. This results in two self-stabilizing ecosystem states: a macrophyte-dominated state with low turbidity, where zooplankton grazing controls phytoplankton growth and a phytoplankton-dominated state, where macrophytes are almost absent because of high turbidity, leaving zooplankton without shelter and therefore unable to control phytoplankton growth. But since Jeppesen et al. (1994) demonstrated that at least one of the main stabilizing mechanisms does not function under brackish conditions, the question whether or not they occur in brackish systems is still not answered.

For the system in focus here, Schiewer (1994) argued about the existence of bistability, because of the rather steep gradients between Hyper- and Polytrophic as well as between the Eu- and Meso-/Eutrophic states (Fig. 8). Such bistability would hamper the re-establishment of the ecosystem state present before eutrophication in the course of the process of remesotrophication. The following ecosystem states were distinguished by Schiewer (1994, see Fig. 8):

I. oligo-mesotrophic conditions, before 1969: nutrient limitation; low biomass of phytoplankton, dominated by diatom species; submerged macrophytes (charophytes) dominating the shallow areas.

II. meso-eutrophic conditions between 1969 and 1981: nutrient limitation, mainly nitrogen; increasing biomass of phytoplankton, dominated by green algae and cyanobacteria; submerged macrophytes (charophytes and potamogetonaceae) dominating the shallow areas.

III. eutrophic conditions: dramatic decrease in macrophytobenthos-cover.

IV. eutrophic-polytrophic conditions: irradiance limitation of phytoplankton, dominated by nano- and picophytoplankton species.

Schiewer (1994) assumed that because of bistability the reoccurrence of macroalgae stands will take decades, his conceptual model (Fig. 8) suggested strong bistability.

But as can be seen from the dataset gathered by Blümel et al. (2002), consisting of the relative cover of macrophytes for the individual parts of the Bodden chain, a reestablishment of macroalgae started already in 1995 and reached levels comparable to the early 1970s already at around 2000, including the re-occurrence of the only species lost in between. Interestingly water transparency, 
thought to be critical for the reestablishment of submersed macrophytes (Krause-Jensen et al., 2008), did not change much in this period, the system is still turbid, exhibiting visibility of $<30 \mathrm{~cm}$ in summer months (Blümel et al., 2002; Domin et al., 2004).

But what caused the fast re-establishment if shading by phytoplankton did not change significantly? The system, being very shallow and oligo-mesohaline in cold winters, gets heavily impacted by ice scraping, removing large parts of the phanerogam community. The ice cover also is shading the system to an extent that phytoplankton almost completely disappears - which, in turn, gives macroalgae a chance to re-occupy areas by their diaspores. Once established, their ability of prolongation growth can successfully override shadowing by phytoplankton in such shallow systems. Therefore, intact diaspore banks and ice conditions are probably the main triggers which give a total reset to the system, overriding bistability factors (Selig et al., 2009).

Resilience in such a case must be defined different from systems dominated by long-living or even perennial species in the disturbed state. In the example presented here, a chance to reestablish successfully is given each year and, if taken, offers the chance of self-stabilization in both ways. In such a situation resilience might be defined as the pure possibility to take the chance of re-establishment of macrophyte meadows, irrespective of whether or not re-establishment occurs in fact. The possibility of re-establishment depends on the existence of a vital diaspore reservoir, which, once established, can serve the ecosystem for several years.

Degradation and resilience of Northern German wetlands (BOR)

(F. Müller)

The following case study demonstrates the dynamics of different disturbances in the wetlands of the Bornhöved Lake District in Northern Germany (see Fränzle et al., 2008). A holistic indicator system that was developed from the viewpoint of orientor theory was applied to demonstrate some steps of wetland retrogression following eutrophication and drainage (see also Müller et al., 2006, 2010a,b; Schrautzer et al., 2007).

Originating in field measurements, ecosystem classifications and maps, different wetland types have been distinguished and modelled with the digital landscape analysis system DILAMO (Reiche, 1996) and the modelling system WASMOD/STOMOD
Table 3

Integrity components and selected indicators.

\begin{tabular}{ll}
\hline Indicandum & Indicators \\
\hline Biotic structures & Number of plant species \\
Energy budgets, exergy capture & Net primary production \\
Energy budgets, entropy production & Microbial soil respiration \\
Energy budgets - metabolic efficiency & $\mathrm{NPP} /$ soil respiration \\
Hydrological budgets - biotic water flows & $\mathrm{NPP} /$ transpiration \\
Chemical budgets - & Net nitrogen mineralization \\
nutrient loss & Nitrate leaching \\
& Denitrification \\
Chemical budgets - & Nitrogen balance \\
storage capacity & Carbon balance \\
\hline
\end{tabular}

(Reiche, 1996) producing simulations of the water budgets, nutrient and carbon fluxes. The model runs are based on a 30 years series of daily data for meteorological and hydrological parameters. The outputs were accomplished by integrity variables (following Müller, 2005, see Table 3 and Fig. 9) and validated by measured data throughout the ecosystem research project in the Bornhöved Lakes region in Northern Germany.

The wet grasslands of the Bornhöved Lake District have been modified by several agricultural measures, such as drainage, fertilization, grazing, and mowing with different intensities. The systems have been classified due to these external input regimes, and in Fig. 9 the sequential consequences of these disturbances are documented synoptically. Throughout the retrogression, there is a high improvement of yield, net primary production (NPP) is increasing by factor 10 . Simultaneously the number of plant species is strongly decreasing. Also the efficiency measures (NPP/soil respiration and transpiration/evapotranspiration) are reduced. The development of the nitrogen and carbon balances shows a strong functional modification from an initial sink function into a source. In parallel the storage capacity is reduced, and all pathways of carbon and nitrogen loss are rising enormously. Summarizing, there has been an enormous decrease of ecosystem integrity. This context raises the question for the resilience of the whole series: is there a way back to an ecosystem state with higher integrity?

To find an answer, intensive data sampling in wetlands all over Northern Germany was carried out, and several time series and successional studies in Northern German wetlands were integrated. By model applications (validated in the broader Bornhöved area) the indicator set of the retrogressional study in Fig. 9 could be

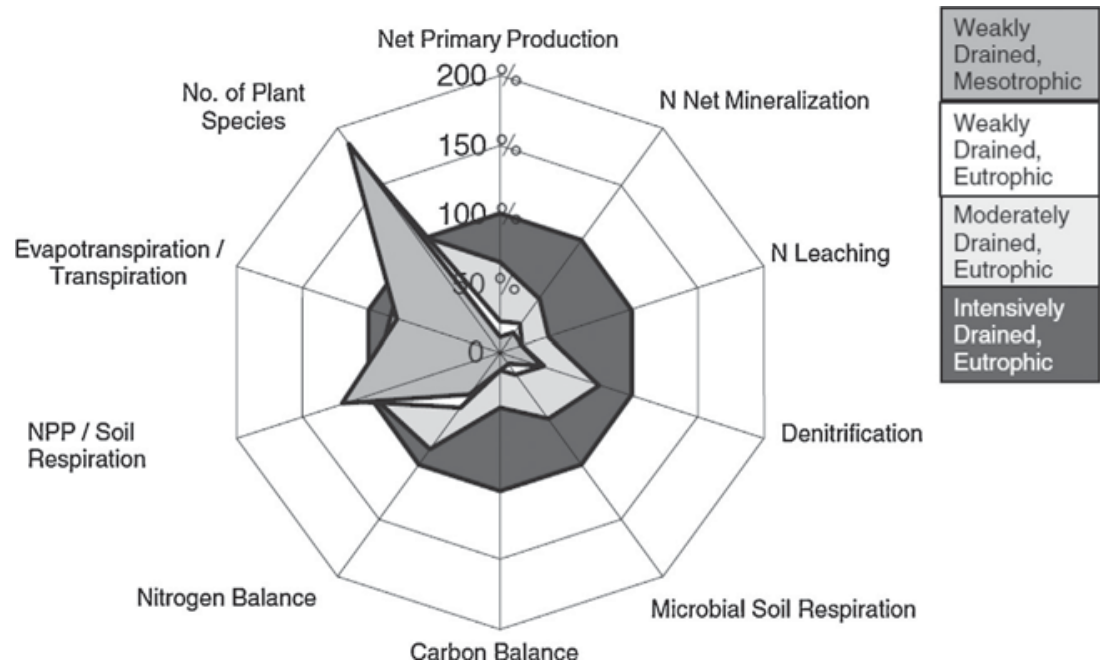

Fig. 9. Integrity indicator development during the retrogression of wet grasslands in the Bornhöved Lake District. The values of the final state (highest degradation) have defined as 100\%, 4 ecosystem types are documented. 


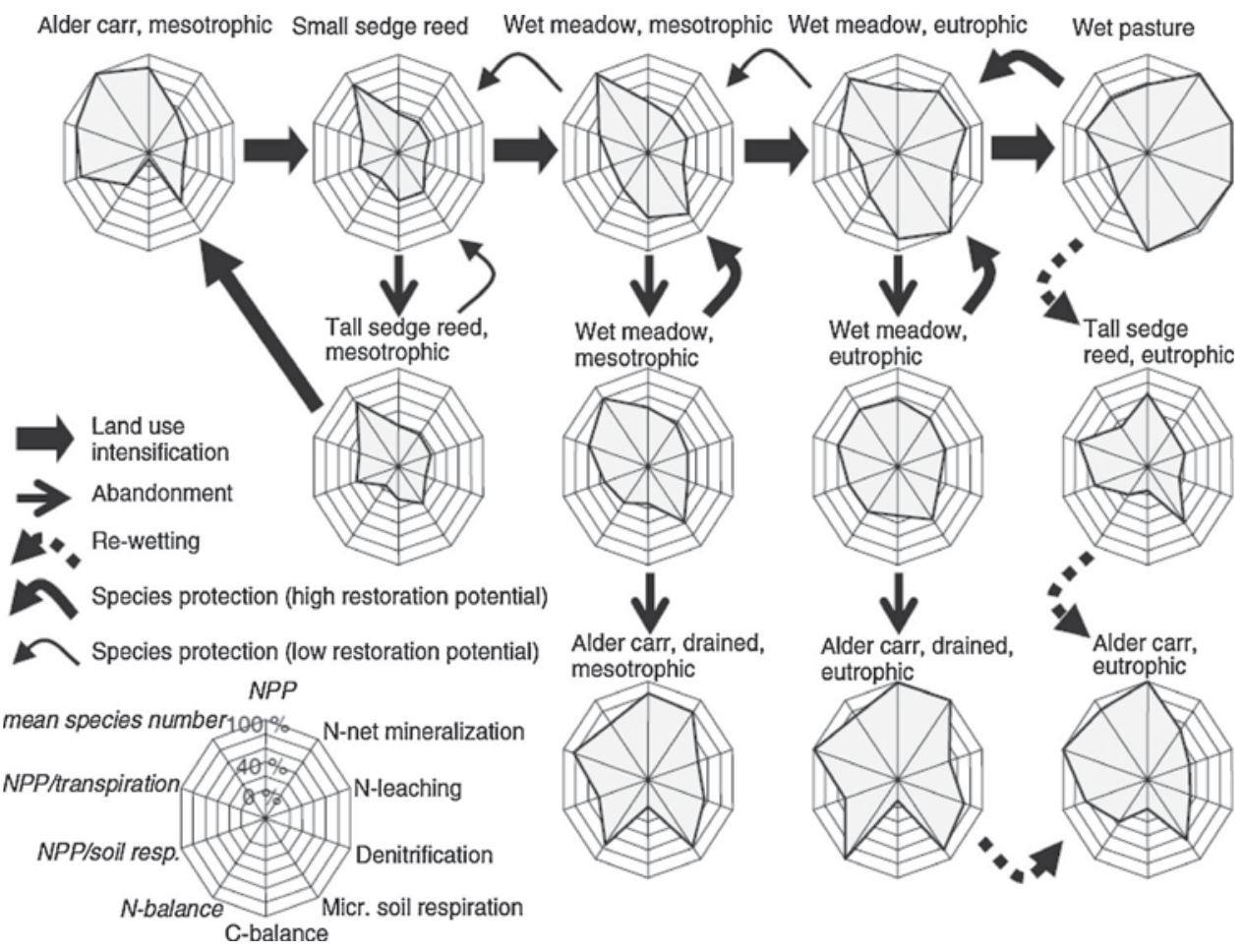

Fig. 10. Spider diagrams of sequential indicator values for ecosystem integrity during a retrogressive succession following land use intensification, and progressive successions following abandonment. The highest parameter values for all successional stages were set as $100 \%$.

After Schrautzer et al. (2007).

quantified for several successional systems states. Fig. 10 shows similar diagrams, representing the selected integrity indicators and using reference values from the total set of sites, whereby the number 100 represents the highest value. The single indicator's position can be found on the lower left side of the figure.

The sequence starts in the upper row with a mesotrophic alder carr. Moving to the right, land use is intensified by deforestation, drainage, eutrophication, grazing and mowing, and in the end the state of a wet pasture is reached, which can be characterized by a low diversity, decreased ecological efficiencies and by a loss of nutrients. To assess the resilience of these states four different management measures were distinguished; abandonment, species protection measures, and re-wetting. In Fig. 10, these modifications are symbolized by different arrows. Studying the successional series, only in one case (alder carr $\rightarrow$ small sedge reed $\rightarrow$ tall sedge reed $\rightarrow$ alder carr) such resilient dynamics are possible. All other series of abandoned ecosystems lead to different ecosystem types, which are depicted in the lower row of the figure. At a first glance, these systems look very similar to the initial state, but concerning the diversity, the metabolic efficiency, the $\mathrm{N}$ balances and the nitrogen loss, the indicator values differ a lot from the starting state. And even such development needs very long return times between 60 and 100 years. Furthermore, the species protection measures mostly enable a one-step-return only and do not re-develop the initial stage. And even if extreme management activities like rewetting are applied, the result will not be identical with the starting point.

This case study may therefore document the normative loading of resilience analyses: the evaluation is a result of the observer's objectives, the selected indicators and the applied thresholds of reversibility. If we define the systems in Fig. 10 structurally only (a lake shore with alder trees), the study's results show resilience, but if we include functional measures or integrity indicator sets, they do not. Another normative point originates in the scale of observation: if we concentrate on the recovery potential of single states, the results might be satisfactory, but if we choose the total retrogressional series, the result will be frustrating. Furthermore, the recovery potential of course also is a function of the selected time scales. One further - may be provoking - hypothesis can be formulated: Degraded and "simple" ecosystems provide a higher resilience than healthy ones (e.g., it might not be hard to restore a simple pioneer system but much effort will be necessary for the restoration of a complex system), they have a much higher buffer capacity than complex systems, but the latter represent a high degree of ecosystem integrity.

Chemical dynamics of the Lange Bramke watershed after intensive forest damage (LAN)

(H. Meesenburg)

Acid deposition has been a major environmental problem for terrestrial and aquatic ecosystems in the northern hemisphere during the last decades. Forest ecosystems at sites with carbonate free bedrock are especially vulnerable with respect to acid deposition as deposition rates are higher than for other ecosystem types due to the filtering effect of the canopy and the introduction of basic substances for fertilization usually doesn't take place. Consequences of acid deposition to forests are the acidification of soils with subsequent mobilization of potential toxic aluminium ions and heavy metals and the transport of these substances including acidity to groundwater and surface waters. The introduction of mobile anions such as sulfate and nitrate causes the leaching of cations from the soil to groundwater and surface waters (Reuss and Johnson, 1985). Aluminium ions are toxic to tree roots and soil microorganisms as well as to aquatic organisms. They may inhibit the uptake of nutrient cations by plants and thus cause nutrient deficiencies and nutrient imbalances (Sverdrup and Warfvinge, 1993; Cronan and Grigal, 1995; Waldner et al., 2012). 


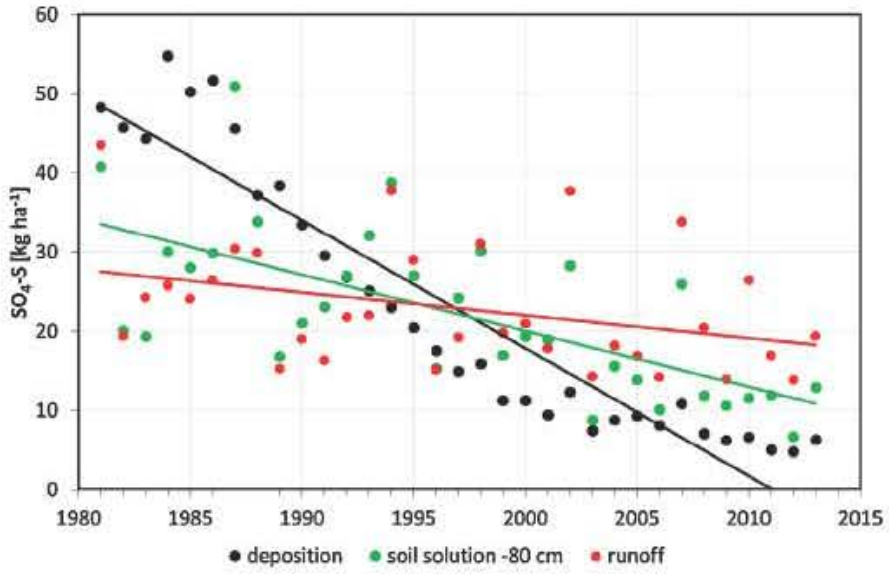

Fig.11. Annual fluxes of sulfate $\left(\mathrm{kg} \mathrm{h}^{-1} \mathrm{yr}^{-1} \mathrm{SO}_{4}-\mathrm{S}\right)$ and linear trends for throughfall deposition, soil solution in $80 \mathrm{~cm}$ depth and runoff at Lange Bramke. All trends are significant $(p \leq 0.05)$.

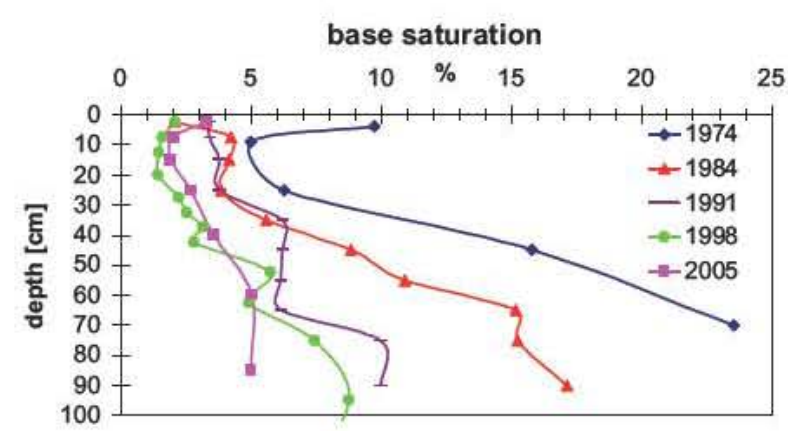

Fig. 12. Depth profile of base saturation at Lange Bramke (plot North Facing Slope). Base saturation is the relative saturation of the cation exchange sites with the sum of $\mathrm{Na}, \mathrm{K}, \mathrm{Mg}$, and $\mathrm{Ca}(\%)$.

The effects of acid deposition on terrestrial and aquatic ecosystems have been studied at the LTER site Lange Bramke since the mid-1970s (Hauhs, 1989). The Lange Bramke catchment (area $0.76 \mathrm{~km}^{2}$ ) is located in the upper Harz Mountains, Germany, and is a tributary to the Oker reservoir. The whole catchment area was deforested by clear cutting in 1948 and reforested with Norway spruce thereafter. Thus, the catchment is stocked with a homogeneous forest stand of today 67 years (Hauhs and Lange, 2010). At Lange Bramke, water and matter fluxes have been studied at the plot scale and at the catchment scale. Intensive monitoring plots are located at the ridge and at the north facing and south facing slopes of the catchment, each representative for about one third of the catchment area.

Since the beginning of the observations at Lange Bramke, the input of acidity has decreased considerably (Meesenburg et al., 1995). Fluxes of sulfate as a major component of acidity decreased also in soil solution and in stream water, but the decline started only at the end of the 1990s and with a lower rate (Fig. 11). This pattern can be attributed to the adsorption of sulfur in the soils (Prechtel et al., 2001). Sulfur adsorption causes a consumption of acidity during periods of sulfur retention whereas a production of acidity occurs, when sulfur is released from the soil (Ulrich, 1994). With respect to sulfur fluxes, the Lange Bramke ecosystem seems to be almost completely resilient, however, a delay of several decades can be expected (Alewell et al., 2000).

The input of acidity caused the acidification of soils in the Lange Bramke catchment as indicated by a decrease of base saturation, which was especially high in the subsoil between 1974 and 2005 (Fig. 12). Below $50 \mathrm{~cm}$ depth, soils drifted from the exchange buffer

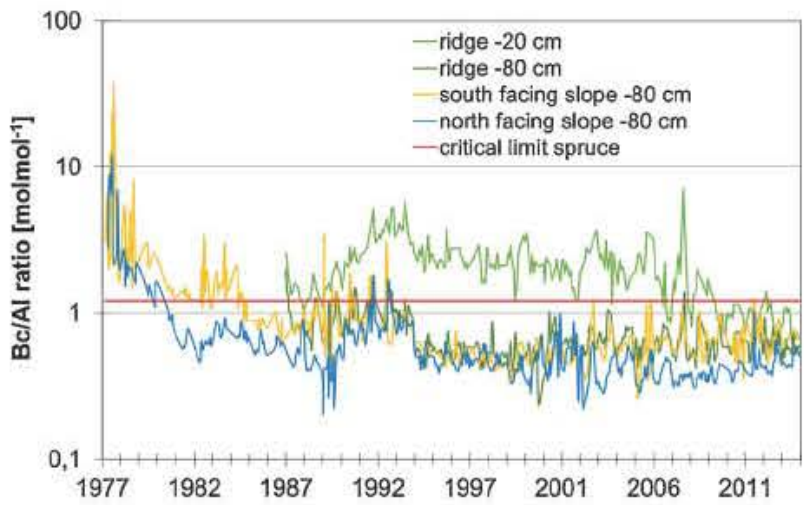

Fig. 13. $B c / A l$ ratio in soil solution at Lange Bramke. $B c / A l$ is the ratio between the sum of $\mathrm{K}+\mathrm{Mg}+\mathrm{Ca}$ and $\mathrm{Al}\left(\mathrm{mol} \mathrm{mol}^{-1}\right)$.

range to the aluminium buffer range. Despite the considerable reduction of acidity input, a recovery of the acid/base status of the soils so far cannot be observed at Lange Bramke. The depletion of neutral cations from the exchange sites seems to be irreversible since rates of silicate weathering are very low and the input through atmospheric deposition has decreased (Alewell et al., 2000; Klinck et al., 2012). Additionally, the utilization of biomass through harvesting causes an export of nutrients leading to a further depletion of pools of neutral cations at Lange Bramke (Klinck et al., 2012).

This transition between different buffer ranges is typically followed by a change in soil solution composition with release of potential toxic aluminium ions into soil solution (Ulrich, 1986). The ratio between neutral cations $(\mathrm{K}, \mathrm{Mg}, \mathrm{Ca})$ and aluminium $(\mathrm{Bc} / \mathrm{Al}$ ratio) in soil solution is a frequently used indicator for potential toxic effects to tree roots (Waldner et al., 2012). At Lange Bramke, the $B C / A l$ ratio in soil solution decreased at the south facing slope and at the north facing slope until the early 1980 s below the value of 1.2 , which is supposed to be a critical limit for potential toxic stress to roots of Norway spruce (Sverdrup and Warfvinge, 1993). Since then $B c / A l$ ratio in $80 \mathrm{~cm}$ depth remained mostly below the critical limit at all three monitoring plots (Fig. 13). In $20 \mathrm{~cm}$ depth (ridge plot), $B c / A l$ ratio was mostly above the critical limit for spruce from the beginning of observations until about 2010, but frequently drops below the critical limit since then. Despite considerable reductions of loads of acidity, a recovery of soil solution with respect to the $B c / A l$ ratio is not detectable at Lange Bramke. The reduction of mobile anions $\left(\mathrm{SO}_{4}\right)$ induced a decline of aluminium contents, but neutral cation concentrations decreased simultaneously because of reduced deposition rates and the deterioration of the exchange complex.

The impact of acid deposition on forest vitality is difficult to disentangle since various drivers are acting at the same time and interactions between them are manifold. At Lange Bramke, nitrogen inputs and climate change are likely improving growth conditions for the Norway spruce stands in the long-term, although negative effects of nitrogen saturation and drought stress may occur concurrently with acidification effects (Meesenburg et al., 2010; Waldner et al., 2012). At Lange Bramke, observations of forest vitality, indicated by defoliation and discoloration started in 1994. Defoliation of forest stands is almost constant with values between 22 and $28 \%$, which is in line with average crown condition of Norway spruce in Lower Saxony. Discoloration as an indicator of magnesium deficiency decreased at Lange Bramke from high values around $25 \%$ to a recently low level.

With respect to the impact of acid deposition, the Lange Bramke ecosystem reveals different aspects of resilience. Sulfate as a major component of acid deposition has been stored in the soils to a large degree causing a delay of acidification. This process 
seems to be predominantly reversible reflecting a high resilience of the ecosystem. Conversely, the deterioration of the pools of exchangeable neutral cations shows no indication of recovery until recently. The transition between buffer systems and the probable disintegration of clay minerals possibly converts the ecosystem to a new attractor domain. How far this process overstrains the adaptability of the ecosystem with respect to ecosystem integrity and vitality of the forest stands remains an unsolved question.

Disturbance in the national park Bavarian Forest: A case study for resilience and non-resilience (BAY)

(J. Müller)

The Bavarian Forest National Park was founded in 1970 at the border between Germany and Czech Republic ( $\left.48^{\circ} 57^{\prime} \mathrm{N}, 13^{\circ} 26^{\prime} \mathrm{E}\right)$, covering $240 \mathrm{~km}^{2}$. The cool, temperate, montane forests of the park are dominated by spruce (Picea abies) at $1150-1430 \mathrm{~m}$, and at lower elevations above $650 \mathrm{~m}$ by mixed stands of spruce, beech (Fagus sylvatica), and fir (Abies alba). Although trees were logged in these mountains in the past centuries to produce charcoal for glass production and to create pastures, human influence was low up to the mid 19s century. At that time, after large windstorms and subsequent damages by bark beetles, modern forestry began and changed tree species composition towards higher proportion of spruce.

In the 1990th several severe disturbances as storms and bark beetle outbreaks affected large areas of the National Park (Fig. 14). These rapid disturbances were enhanced also by global warming. This evoked the question about resilience of these forests in many facets. Two of them will be illuminated here.

The first expectation by forest ecologists was a turnover in the tree species composition towards pioneer species and the naturally dominant species of the slopes, beech and fir after disturbance. This expectation was poorly fulfilled. Stand replacing disturbances in spruce stands were followed by an extensive spruce regeneration as direct regeneration (Ilisson and Chen, 2009). Thus the killing of the mature spruce trees by bark beetle mostly favoured spruce itself (Fischer and Fischer, 2012). This is in line with findings from arthropods involved in the decomposition of the dead wood. Here species most favouring the open canopy independent from the wood amount were specialists of spruce dead wood (Müller et al., 2010a,b). Thus not only spruce but also related species were favoured. Why is there so less response in tree turnover despite the heavy disturbance? On explanation here is that in spruce forests killed by beetles no bare ground is available for pioneer trees (Jonášová and Pracha, 2004). Moreover, the dominant seed storage in such stands consists of spruce. In summary these findings from tree regeneration and related fauna underline that direct regeneration after stand replacing disturbance is inherent for montane spruce forests and despite several thousand hectares of disturbed spruce forests the systems seems resilient also under the current climate warming.

The second perspective which will be mentioned here is the response of plants, arthropods and birds. Based on more than 100 year old inventories, it could be shown that species of three arthropod taxa (Syrphidae, Hymenoptera, Coleoptera) clearly shifted their upper range limits towards higher elevation, more than expected by the mean annual temperature increase (Bässler et al., 2013). In the same time, plant revealed no upward shift, and birds only showed a slight shift. One trait which could be identified as critical for species to shift or not was colour (Zeuss et al., 2014). In the National Park pale beetles displayed the most pronounced upward shift, while dark beetles already colonized higher
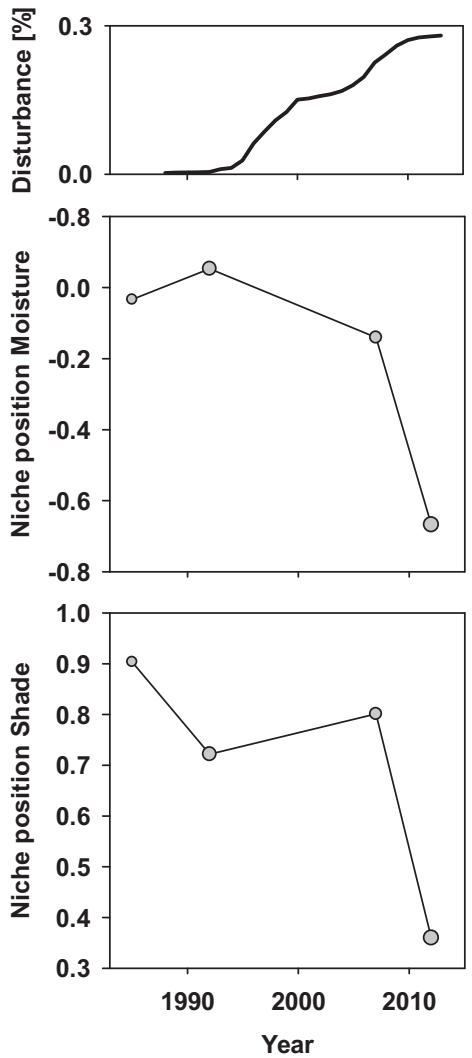

Fig. 14. Functional composition of the spider fauna in the National Park Bavarian Forest with respect to two important species traits, the niche position canopy cover and the niche position moisture (Entling et al., 2007). The size of the dot is scaled by the number of individuals (1984-85: 1596, 1992-1994: 20,772, 2006-2007: $5785,2011-2012: 43,361)$. The upper panel displays the percentage of the National Park area affected by stand replacing disturbances of bark beetle and windthrows cumulative over time.

elevations hundred years ago. A deeper view inside the warming effects in the National Park revealed a $+4^{\circ} \mathrm{C}$ in April while mean annual temperature increased only by $1.1^{\circ} \mathrm{C}$ (Bässler, 2008). This might explain that many arthropods as beetles particularly active in spring are more affected than plants acting over the whole growing season. In summary these findings underline the perspective that current communities in these forests experience a new reassembling of species, with unknown consequences for the ecosystem functions.

However, not only the comparison with old data supports this view, shifts in functional composition of species can be observed also during the last three decades. Spiders were sampled throughout the National Park in four larger events, during the 1985th, the early 1990th, in 2007 and during 2012th. For a majority of these species niche traits exist for canopy density and moisture in Europe (Entling et al., 2007). The analysis of the mean spider composition in the National Park reveals the pattern of a shift towards species favouring less moist and more open canopies, again no signal for resilience so far. However, it is difficult to distinguish between direct effects of climate warming by increase in temperatures and a decrease in precipitation and indirect effects via the canopy reduction by disturbances. Nevertheless, the species specific response to climate (Bässler et al., 2009) and disturbance (Beudert et al., 2015) or both, mediated by their traits and considering the various functions of species in ecosystems, an ongoing shift in communities and also in ecosystem processes and functions is much more reliable than a simple return to a starting point. 


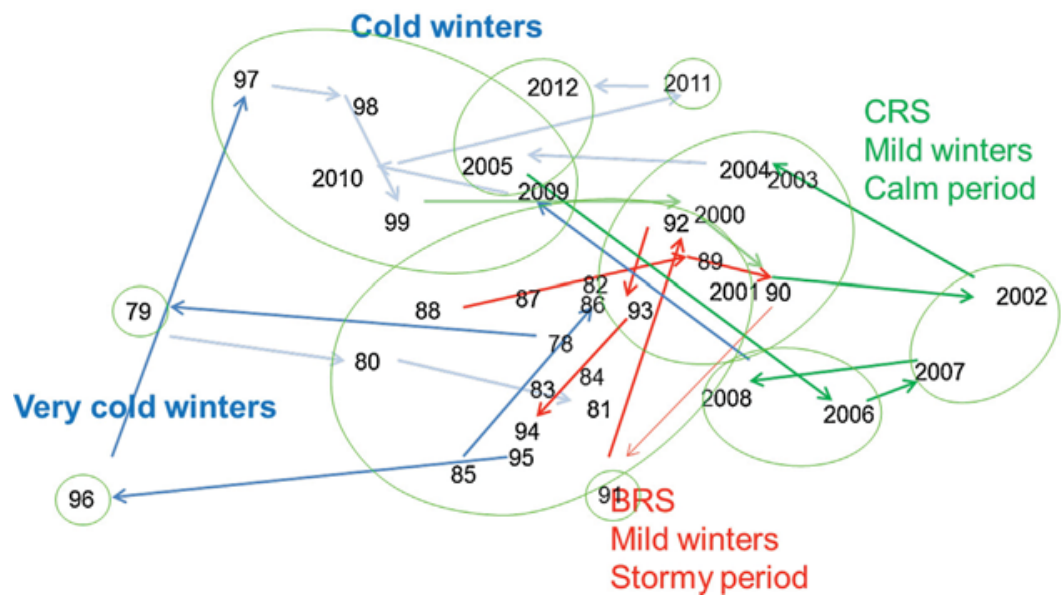

Fig. 15. MDS for 2nd quarter macrofauna abundance from 1978 to 2012. Very cold and cold winters: blue arrows; BRS: biological regime shift, red arrows; CRS: climate regime shift, green arrows. (For interpretation of the references to colour in this figure legend, the reader is referred to the web version of the article.)

\section{Effects of cold winters and regime shifts on the macrofauna} community off the island of Norderney (NOR)

(I. Kröncke, J. W. Dippner)

Biological regime shifts (BRS) in marine ecosystems often occur in connection with climate regime shifts (CRS) as documented in different areas in the oceans and result in a reduction of species diversity (Dippner et al., 2014). CRS are often considered as changes in the trend of global mean air temperature (Swanson and Tsonis, 2009). BRS, which are not well defined, have been classified into smooth, abrupt or discontinuous depending on the nature of external forcing (Scheffer et al., 2001). In this descriptive classification, a smooth BRS is characterized by a quasi-linear relationship between driver and response variables. An abrupt BRS is represented by a non-linear relationship between driver and response variable. Over the past few decades, climate indices e.g. the North Atlantic Oscillation (NAO) index (Hurrell, 1995) were used to identify the response in marine ecosystems (Dippner, 2006). Several long-term studies in the North Sea have revealed changes in plankton, benthos and fish stocks since 1988 , which were directly or indirectly related to the NAO winter index (e.g. Spencer et al., 2011; Kröncke et al., 1998, 2013).

Two CRS and BRS occurred during the last 35 years: 1988/1989 and 2000/2001. The first CRS separates two longer lasting climate regimes: a persistent NAO- period from 1977 to 1988 followed by a persistent NAO+ period from 1989 to 2000 (Dippner et al., 2014). For 1978-1999, the NAO winter indices were highly correlated to the time series of Norderney macrofauna in the following spring (Kröncke et al., 1998; Dippner and Kröncke, 2003). This indicates a smooth BRS in 1988/1989. After 2000, the NAO lost its persistency and the autocorrelation disappeared, while the variance in the benthos data increased indicating an abrupt BRS. Therefore since 2000, the correlation of NAO index and the structure of macrofauna communities disappeared (Dippner et al., 2010, 2014).

Five stations (water depth 12-20 m) were sampled with RV "Senckenberg" north of the island of Norderney (Kröncke et al., 2013). The macrofauna community off Norderney represents a Tellina (Fabulina) fabula community, which is characteristic for the southern North Sea in well mixed waters. Since 1978 the sampling procedure is unchanged. A $0.2 \mathrm{~m}^{2}$ van Veen grab has been used and the samples have been sieved with $0.63 \mathrm{~mm}$ mesh size. One replicate was taken at each of the five stations. The samples were fixed in $4 \%$ buffered formaldehyde. Biomass was determined as ashfree dry weight per $\mathrm{m}^{2}$. Samples were dried for $24 \mathrm{~h}$ at $85^{\circ} \mathrm{C}$ and burned for $6 \mathrm{~h}$ at $485^{\circ} \mathrm{C}$. Multidimensional scaling (MDS) ordination was carried out on species abundance data using the Primer (6.1) software package, employing the Bray-Curtis similarity index and square-root transformation.

The MDS plot for abundance of the 2nd quarter (Fig. 15), which is representative for all other quarters, reflects significant changes in community structure caused by the very cold winter 1978/79. After the winter, the community structure seemed to recover to an earlier state and remained similar during the early to mid 1980s. The smooth BRS in 1988/89 associated with a rising positive NAO index, mild winters and strong westerly winds led to changes in the community structure in the early 1990s. The very cold winter 1995/96 followed by a less cold winter 1996/97 resulted again in a significantly different community structure, but the community seemed to recover until 1999 to a state similar to the early 1990s. In 2000 and 2001, under the CRS associated with mild winters but lesser storms, the community shifted to a significantly different level in 2002, while in 2003 and 2004 the community structure returned again to a structure similar to 2000 . In 2005 , the community was similar to the cold winter communities from the 1990s, while in 2006-2008 it shifted again significantly and was similar to the 2002 community. From 2009 to 2012, a period with cold winters, the community structure was similar to earlier cold winter communities. To summarize, the MDS for the 34 years data revealed four groups of community structure: the very cold winter community, the cold winter community, the after CSR/BRS 1988/89 community and the after CRS/BSR 2000/2001 community.

The MDS reveals the severe effects of very cold and less cold winters on the community structure. Mortality due to low temperatures was the major stressor affecting the Norderney communities similar to other studies from the Wadden Sea and the coastal North Sea (see Kröncke et al., 2013). The recovery to the preceding community state of the Norderney community after very cold and cold winters was also common in the other studies mentioned above and seems to be a hint for community resilience. Also Beukema (1990) and Reise (1994) stated that cold winters may even stabilize the Wadden Sea ecosystem.

The smooth BRS in 1988 changed the Norderney macrofauna community structure significantly and was associated with rising SST, rising (positive) values of the NAO winter index and increased storm frequency. The changes in community structure were caused by increases in species numbers, abundance and biomass of native 
southern species such as the bivalve Tellina fabula, which probably benefitted from the BRS enhanced primary production in coastal North Sea regions (McQuatters-Gollop et al., 2007). The CRS in $2000 / 2001$ resulted in the warmest years in the global instrumental record, but decreasing NAO index and storm frequency (Loewe, 2009). The CRS and BRS in 2000/2001 caused a significant change in Norderney macrofauna community structure and a decrease in species number, biomass and diversity until 2005 (Kröncke and Reiss, 2010), but massive recruitments of polychaetes such as Spiophanes bombyx and Owenia fusiformis, the bivalve T. fabula and the sea-urchin Echinocardium cordatum in 2003, 2006 and 2007. In contrast, the abundance of the eurytherm and interface-feeding polychaete Magelona spp. decreased drastically after the CRS/BRS. This might be due to competition for food with other species such as $T$. fabula, because primary production also decreased simultaneously in the coastal area during the last decade (van Beusekom et al., 2009). In contrast, the abundance of the tube-building polychaete Owenia fusiformis and the burrowing amphipod Urothoe poseidonis suddenly increased after the CRS. Since both species prefer more stable sediments, their higher abundance in contrast to the decreasing abundance of mobile amphipods (Bathyporeia spp.) and bivalves (Donax vittatus) seems to be related to calmer hydrodynamic conditions as confirmed by the lower storm frequency since 2000 (Loewe, 2009). The increase of variance in benthos data, which is also documented in a higher dissimilarity (Fig. 15), indicates an abrupt BRS.

In contrast to the resilience of community structure after cold winters, the BRS and CRS shifted the community structure to a different level with increasing diversity and changing dominance of native species as well as the presence of non-native species. Such changes in macrofauna communities were found not only found off Norderney, but in the entire southern North Sea up to the $50 \mathrm{~m}$ depth contour. This process requires adaptation to the new level. Dippner et al. (2010) and Junker et al. (2012) confirmed the significant post CRS shift in community structure because they could show that the fluctuations in the Norderney macrofauna communities in the 2nd quarter became unpredictable due to a switch in climate systems over the northern hemisphere, which was related to the loss in persistency of NAO index (Dippner et al., 2014; Dippner and Kröncke, 2015) (Fig. 16).

Intertidal blue mussel stock (Mytilus edulis) in the Wadden Sea of

Lower Saxony - decline and re-colonization after the cold winter 1995/1996 (WAT)

(G. Millat)

Until the end of the nineties of the last century the blue mussel (Mytilus edulis) was the only bivalves species in the Wadden Sea National Park of Lower Saxony, which was living on - and not in - the sediment of the intertidal mudflat, before the pacific oyster (Crassostrea gigas) started an invasion in 1998. The aggregation of the mussels is responsible for musselbeds, which are the only natural hard substrates in the Wadden Sea. They serve as biotopes, retreat areas, attachment options, hiding places and niches for up to 100 plant and animal species. Further functions are related to the provision of food for many animals of the Wadden sea and for creating structures with hydrodynamic relevance, demonstrating the multitude of ecological functions and their high relevance in the Wadden areas (Millat, 2014).

Due to this extraordinary relevance and the economic significance of the mussels for human food provision, since 40 years analyses of the blue mussel stock have been carried out in Lower Saxony. In order to characterize the mussel stock, both variables have been measured regularly, the area covered by the mussels and their biomass (living wet weight). The first synchronous total survey, basing on an analysis of aerial photos, was executed in 1975 and resulted in a total area of musselbeds of about 5000 ha (see Fig. 17). The subsequent analysis from 1989/91 revealed a decline to an area size of only 2.700 ha. The decrease continued, and in 1994 the area of musselbeds was reduced to 1300 ha (Obert and Michaelis, 1989, 1991; Michaelis et al., 1995; Herlyn, 1996, 2009; Zens et al., 1997; Millat and Herlyn, 1999; Millat, 2006).

In spite of several investigations, no single steering factors for the described dynamics could be discovered until the mid of the nineties (Millat and Herlyn, 1999). It was the winter 1995/1996 when a first causal relation between the mytilus stock and the ice dynamics of the North Sea could be elaborated. This season was one of the coldest winters of the last 70 years, reaching 50 days with ice coverage. These conditions were responsible for a disturbance of nearly the whole mussel expansion in the area, which only attained 170 ha at that time. In the summer of the same year (1996) a strong re-colonization was observed, when young mussels were recruiting the residuals of former sites but also extended their living area to new sites in the Wadden sea. A mapping campaign in the autumn of 1996 resulted in a covered area of 1457 ha. The young mussel populations could overcome the following strong winter (ice cover during 30 days) and in 1997 the covered area had a size of 1278 ha, a similar magnitude as in the autumn before. In the following period an areal expansion of the 1996 cohort was observed, supplemented by some cases of local mussel spatfalls. As a consequence, in 1999, the covered area was attaining a size of 2900 ha.

Referring to the total biomass, data are available since 1989/91 (Obert and Michaelis, 1989, 1991). The smallest biomass has been measured during the winter 1995/1996 with about 1000t (see Fig. 18). Even though the percentage decrease of the biomass from 1999 to 2005 (from $110,000 t$ to $9000 t$ ) is pronounced much stronger (90\%) than the areal decrease (65\%), there are strong parallels between these two indicator classes.

Summarizing it can be stated that the blue mussel stock needed 3-4 years in maximum for their regeneration after suffering from the effects of strong, ice-covered winters. Compared to previous decades the blue mussel stock is now at a minor lower level, but for several years stable (Millat et al., 2009, 2012).

Fish assemblages in German rivers: Do we get back to historical reference conditions? (HES)

(S. Stoll \& P. Haase)

During the last centuries, streams in Germany have become increasingly degraded. Streams were channelized, their floodplains were drained and intense agriculture and discharge of household sewage waters resulted in severe eutrophication problems. During the last decades, political awareness for environmental issues, however, has increased. This development in public opinion has stimulated a number of legislations setting standards for environmental conservation.

Concerning aquatic ecosystems, the most important legislation in the European Union is the EU Water Framework Directive (WFD), which demands that natural surface waters have to be brought to good ecological conditions (European Commission, 2000). To reach these conditions, currently sewage treatment plants are built and morphological stream restoration projects are carried out throughout the whole European Union, worth more than a billion Euros per year. Aquatic organisms are often used as indicators of the ecological conditions, as they integrate ambient stressors on a long-term basis and as they are thus more reliable indicators of ecosystem state than individual point measurements of stressors in highly dynamic stream ecosystems. 


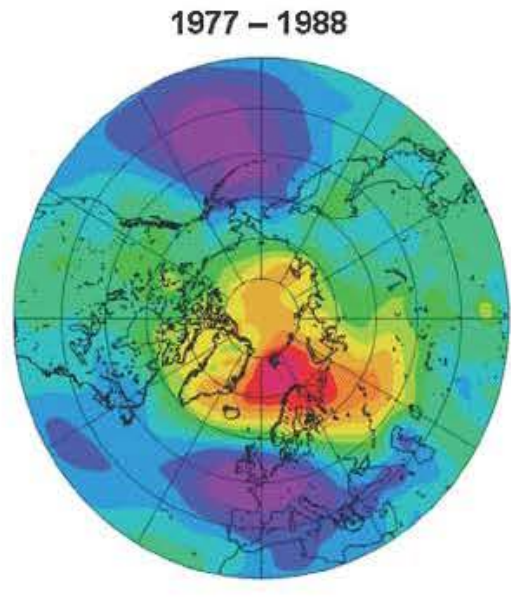

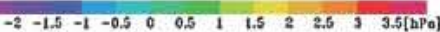

$1989-2000$

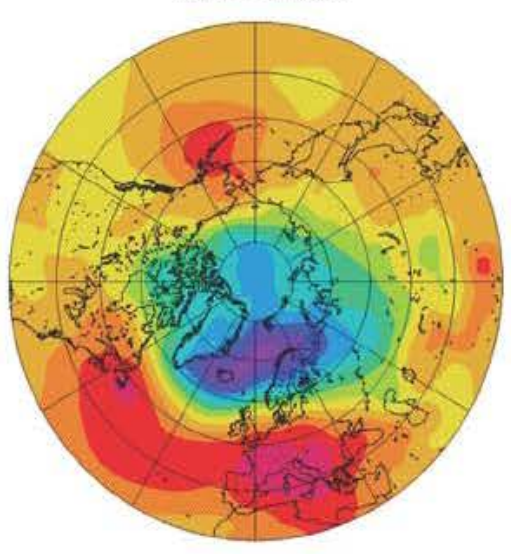

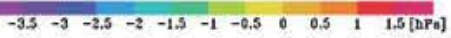

Fig. 16. Winter (Dec-Mar) sea-level pressure for the periods 1977-1988 (left) and 1989-2000 (right) from Dippner et al. (2014).

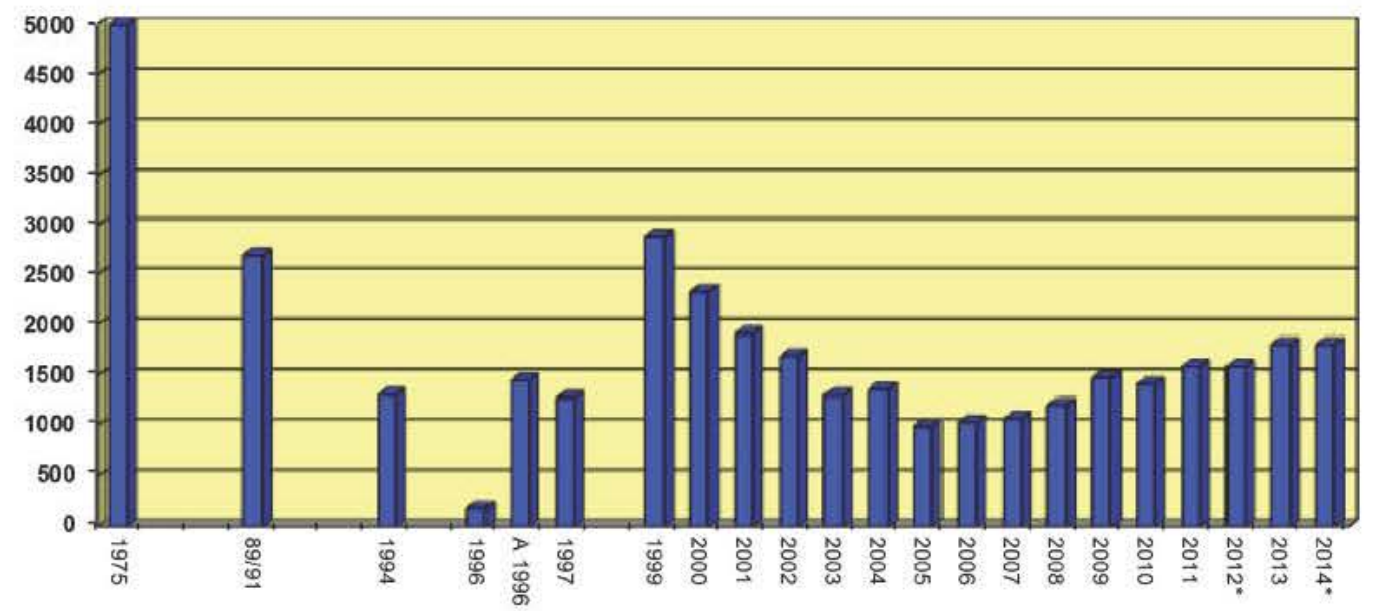

Fig. 17. Total area (ha) of intertidal blue musselbeds in the Wadden Sea of Lower Saxony in spring/summer between 1975 and 2014 (exception: autumn 1996 ); "due to weather conditions an aerial survey was not possible in 2012 and 2014; data transferred from the previous year.

The implicit assumption behind these restoration activities is that if stream habitats are brought back to natural conditions, also the communities will return to their natural reference conditions (Haase et al., 2013). This assumption is predicated on a resilient behaviour of communities, as it is expected that with the discontinuation of a stressor regime, communities will return to a pre-stressed status. In the present analysis, this view is questioned at the example of fish, because fish communities are used as one

\section{in $1.000 \mathrm{t}$}

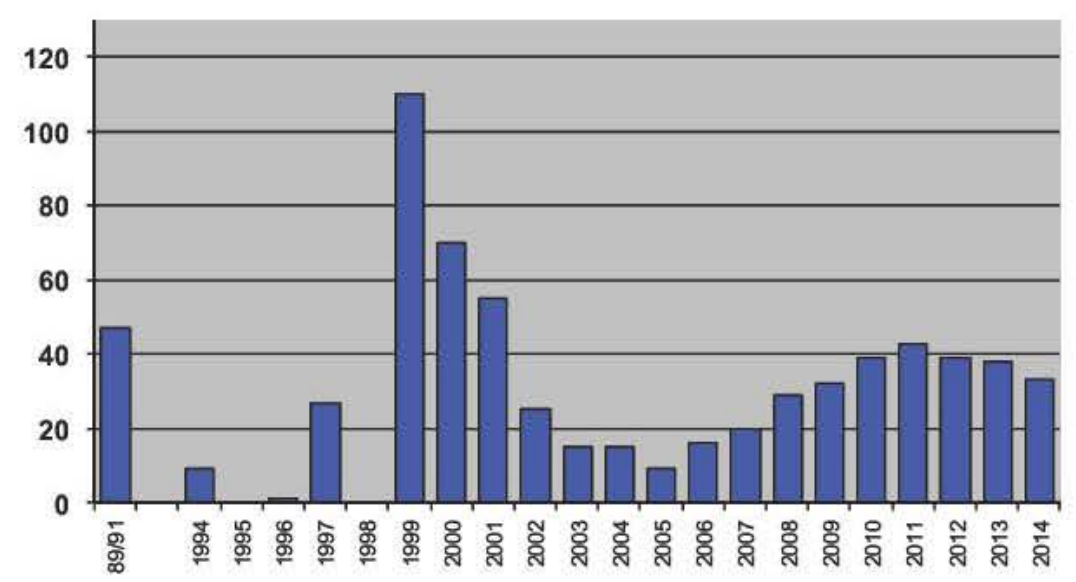

Fig. 18. Development of the total biomass (living wet weight) of the intertidal blue mussel stock. 

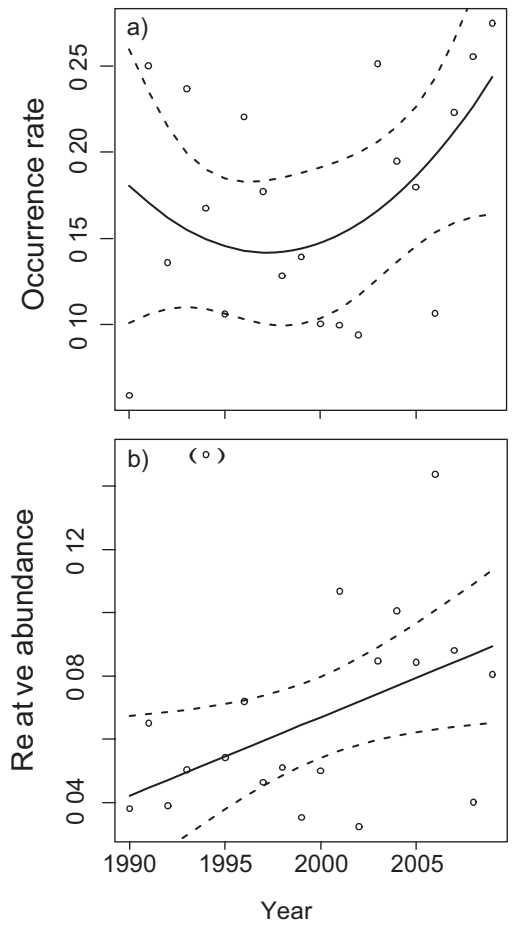

Fig. 19. Occurrence rates (a) and relative abundances (b) of alien fish species in Hesse and North Rhine-Westphalia, Germany from 1990-2009. Dashed lines delimit $95 \%$ confidence intervals. In (b), the year 1994 was omitted from the analysis, as this outlier to the data was driven by one stream that was exclusively inhabited by rainbow trout. In comparison, the occurrence rate of alien species in the same year does not show any anomaly.

important indicator group for the ecological conditions of streams. We raise the hypothesis that we cannot expect a resilient behaviour in fish communities, as the underlying assumptions ignore ecological realities.

A key criticism is that the historic reference communities that restorations are aiming for do not include alien species (neobiota). However, in most stream systems, the presence of alien species is an irreversible fact. Streams are among those ecosystems that are affected most by alien species. Thus, remediation of stressor regimes is not likely to bring back historical fish reference communities, but novel communities including alien species, which may have different ecological characteristics than the historic communities. The present study examines (1) the temporal trend in the occurrence rate and relative abundances of alien species within German stream fish communities and (2) how the ecological species traits, and thus the ecosystem functions within fish communities, differ between native and alien species. The dataset and methods that were used to study these questions are presented in detail in Appendix 1.

Both occurrence rates and relative abundances of alien fish species were increasing from 1990 to 2009 (Fig. 19 and Table 4). In 2009 , on average, at about $25 \%$ of all stream sites alien fish species occurred. Within fish communities containing alien species, on average about $10 \%$ of the fish individuals belong to an alien species. In individual cases this proportion can be as high as $100 \%$. There is no provision for the assumption that these trends will be reversed in the next years.

These alien species that currently increase in occurrence rates and relative abundances feature different ecological characteristics compared to native species (Fig. 20). Two distinct groups of alien fish species can be distinguished, the first in the lower right sector comprising species that are small-bodied (bl1), shortlived (ls1), fast-reproducing (ma1) fish that lay few eggs (fe1) and practice parental care (npy). This set of species was typically introduced unintentionally and some of these species are considered as nuisance or even pests, e.g. goby species. A second group of alien species comprise predominantly large (bl3), rheophilic (rhe), torpedo-shaped (sh2), inverti-piscivorous (d_inp) gravel-spawners (lit). This set of species includes all salmonid species that were intentionally introduced for fishing purposes. All these alien species are typically not deep-bodied (sh1), long-lived (ls3), potamodromous (pot) species with an r-selected reproduction strategy, combining high number of eggs (fe3) with small egg sizes (ed1) and no parental care (npc), which are characteristics predominantly characterizing native fish species (Fig. 20). Hence, alien species typically not only replace native species in stream fish communities, but induce shifts in the composition of ecological species traits that are related to functional aspects of stream fish communities.

In consequence, the reduction of environmental stressors currently does not lead to a resilient response of stream fish communities developing back to historic reference conditions as expected and aimed for by the WFD. Instead, this process of community change in response to environmental improvement is superimposed by a parallel process of invasion (intentional and unintentional) of alien species. Also these alien species profit from the better environmental conditions created by stream restoration, leading to novel communities with different functional characteristics than the historic communities that occurred in the respective streams before the onset of habitat degradation.

Analysing Trends in the Biogeochemistry of a Beech Forest Ecosystem (BHF)

(C.G. Schimming)

In the context of ecosystem research in the Bornhöved Lakes Region, data and information were collected in long-term series nearly 20 years long contributing to a deeper understanding of the dynamics of eco-systemic structures and functions (Fränzle et al., 2008). Environmental monitoring in a deposition loaded and strongly acidified beech forest ecosystem produced data on biogeochemical dynamics in the soil solution, of which the temporal resolution allows for the assessment of impulse-response relationships as well as special focus on resilience emergence (Schimming et al., 2011). Like for the Bornhöved Project, the challenge of assessing these fluctuation aspects in ecosystems will also draw attention to the emergence of resilience and the opportunities of using monitoring and existing data series available from Long-Term Ecosystem Research (LTER).

However, LTER's and other useful data come from monitoring mostly in the field of individual entities and various objectives (Schimming et al., 2010) but respectively in mostly reductionistic perspectives. Therefore it has at first only limited value for analyzing dynamics of structures and functions concerning the ecosystem and its resilience as a whole. This is due to the lack of considering ecosystems are hierarchical organized. Moreover, there is little knowledge about the fact of alternate states on any observation scale as being emergence of non-linear process interactions bottom up whilst the development is constrained by the conditions of the respective parent system scale top down at the same time (Jørgensen, 2012). Consequently, external impulse e.g. by mass action on the ecosystem will be compensated in process interactions between the different scales and only belatedly get emergent on the scale of the total ecosystem, i.e. because of lack in holistic and operable indicators. However, as ecosystems perform the biospheric interface between the biotic and physical environment, they are reducible to external energy or mass exchange whereas the 
Table 4

Results of the regression analyses on the trends of occurrence rates and relative abundances of alien species in German streams.

\begin{tabular}{|c|c|c|c|c|c|c|}
\hline \multirow[t]{2}{*}{ Variable } & \multicolumn{3}{|l|}{ Occurrence rate } & \multicolumn{3}{|l|}{ Relative abundance } \\
\hline & Estimate $\pm \mathrm{SE}$ & $\mathrm{P}$ & $R^{2}$ & Estimate $\pm \mathrm{SE}$ & $\mathrm{P}$ & $R^{2}$ \\
\hline Intercept & $6.4 \pm 2.7 \times 10^{3}$ & 0.0313 & & $-10.8 \pm 4.6$ & 0.0308 & \\
\hline Year $^{2}$ & $1.6 \pm 0.7 \times 10^{-3}$ & 0.0311 & 0.30 & $5.5 \pm 2.3 \times 10^{-3}$ & & 0.26 \\
\hline Year & $-6.4 \pm 2.7$ & 0.0312 & & & 0.0273 & \\
\hline
\end{tabular}
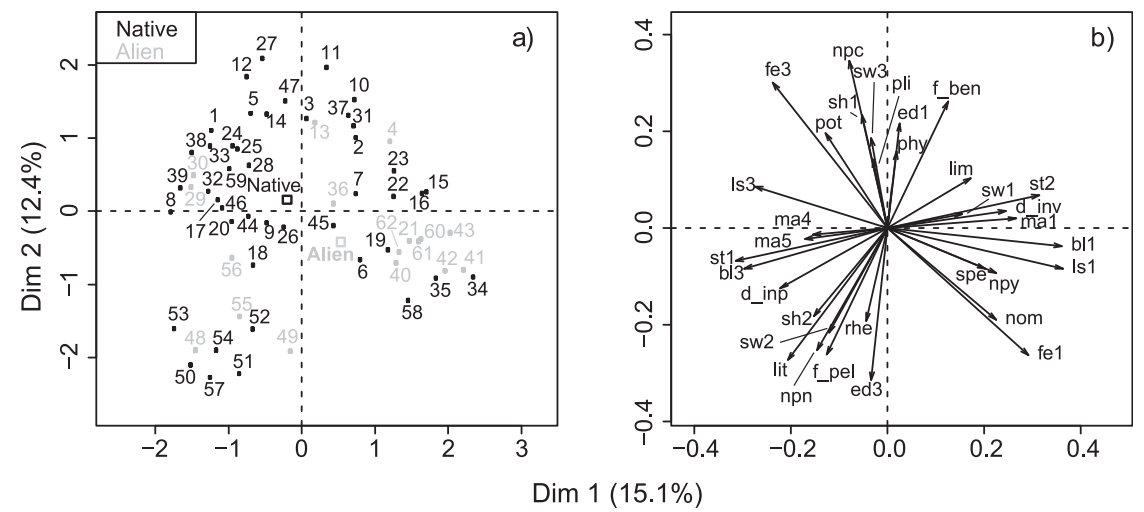

Fig. 20. Individuals (a) and variables (b) factor map from PCA analysis on the distribution of ecological species traits in native and alien fish species. In (a), open squares indicate centroid for the groups of native (black) and alien (grey) species. In (b), only traits that correlate significantly ( $p<0.01$ ) with dimensions 1 and 2 are shown. The number code of species and the full list of species traits are given in Table S2 in Appendix 1.

efficiency of the productive system and related quantities reflect the emergent properties attributed on the entire system.

In this kind of holistic view of ecosystems, the dynamics of biogeochemistry was considered as an indicator for resilience performance also of ecosystems comprising all the entire mass action of productivity, growth and environmental relationships. Consequently the emergence of structural development and networking of ecosystems inevitably exists in the form of chemical change in environmental media, whereas the relationships with the atmosphere are biospheric, whilst the soil solution possesses the almost dense ecological interference and chemical sensitivity for change and performing resilience on the ecosystem scale. On this theoretical background, the biogeochemical performance of resilience was observed by trends and periodicities in the biogeochemistry respectively the soil solution (Fränzle and Schimming, 2008).

Under the varying mass action in the beech-forest ecosystem, time-variant activity curves of nitrate $\left(\mathrm{pNO}_{3}{ }^{-}\right)$, aluminium ( $\mathrm{pAl}$, aluminium assumed mostly speciated as $\mathrm{Al}^{3+}$ ) and of all cationic species in a charged balanced activity ( $1 / n$ pMe) during 1989 to 2008 show several periods of differing trends and more or less inversed relationships with the $\mathrm{pH}$ curves (Fig. 21). The timevariant $\mathrm{pH}$ curves as well as the activities of components coming from the soil-base stock are oscillating in compliance with effective buffering.

In the biogeochemical context, dissolved and highly mobile inorganic and significantly polar species in the $\mathrm{H}^{+} / \mathrm{H}_{2} \mathrm{O}$ system reflect the standard of almost lowest energy states of elements in contrast to those forming the more stable and energy-rich organic compounds of structured biomass accumulating the nutrients in more or less non-polar bounds after uptake from the environmental media. The resulting dynamics of both, gradients in the field of developing ecosystem structures, chemical potentials and of the source and sink strengths are thus the ultimate phenomena and assumingly emergence of ecosystem resilience, which is the funding hypothesis and comprising the universal scientific criteria of thermodynamics. In this regard, biogeochemistry in ecosystems reflects ecosystem response on external impulses also including compensation and constraints within the hierarchy of ecosystems.

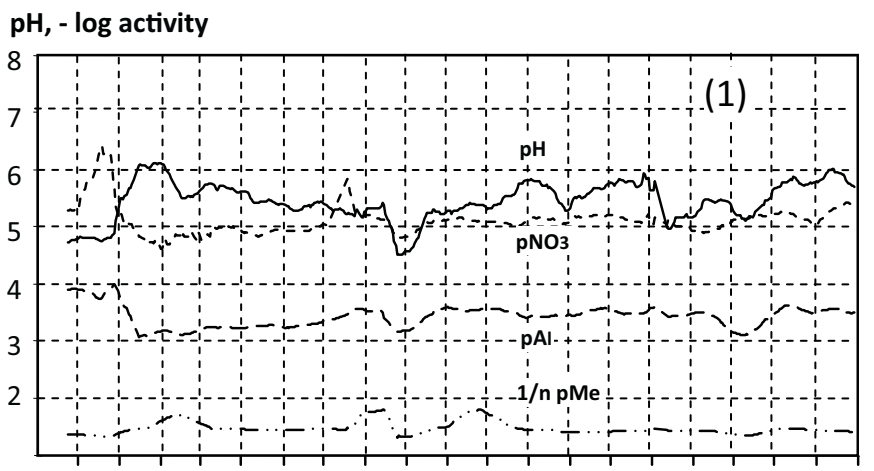

\section{Vol \%}

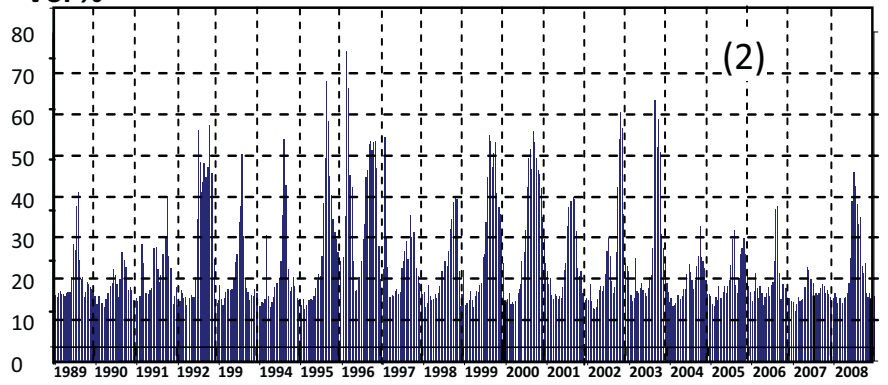

Fig. 21. Time variance of $\mathrm{pH}$, activities of nitrate $\left(\mathrm{pNO}_{3}{ }^{-}\right)$, aluminium $(\mathrm{pAl})$ and metals (pMe) in the term of charge weighted values together with indication of the $\mathrm{pH}$ trend (1) showing the context with soil water contents (2)) in a mineral subsoil horizon ( $150 \mathrm{~cm}$ soil depth).

The apparent resilience obvious from the pattern of the timevariant curves (see Fig. 21) is probably seasonal while coinciding, with here two to three longer cycles as suggested by changing trend of the curves. The reflected change of chemistry and related intensity also explain the imbalance in the mass action of $\mathrm{NO}_{3}$ uptake, reduction and accumulation of nitrogen for biomass production (Fränzle and Schimming in Fränzle et al., 2008) and temporal shifted release of oxi-anionic nitrate through respiration 
(oxidation). The relationships and non-linear trends respectively correlate with the acidity load coming from coupling of hydrolysis and redox-processes in the productive transfers of the nonconservative element nitrogen as well as dynamic buffering at the interface with the soil solution. The almost significant performance in particular of $\mathrm{pH}$ is seen for the year 1996, indicating a chemical response on severe impulses by exceptionally high and intense rain fall events and consequent high soil-water intensity followed by a period of drier conditions which modified chemistry in the acidification processes mostly by mass action of nitrogen mineralization, leaching and of unrecyclable nitrogen additionally coming from persistent atmospheric deposition overload of acidifying air pollutants.

The existing structural properties in particular of vegetation (Irmler et al., 2008) indicate that even under the regime of intense soil acidity and low base saturation (Blume et al., 2008) covering the rooting zone, there is still sufficient capacity to sustain the seemingly existing longer term resilience (cf. Fig. 21) of the investigated ecosystem although the potentials are in particular low in the considerably sandy subsoil but comparably higher with more loamy sand in the rooting zone (cf. Blume et al., 2008).

Frequency distributions of $\mathrm{pH}$ values for selected years in the same observation period (1989-2008) (Fig. 22) follow a significantly higher variability of $\mathrm{pH}$ than in the less sandy upper mineral horizons and the Ah (see Schimming et al., 2011). Assuming resilience even under these conditions, the impulses on the system may be infrequently compensated and responded by buffering already before a next instantaneous disturbance follows. Consequently there are differently directed offsets in the mean values of the oscillation of chemistry. Seemingly there is performance of a longer period than for certain seasonality. Thus, the hypothesis of two different buffer systems functioning resilient on two different stability levels has been developed. The one buffer component, reacting relatively fast and closer to equilibrium, is determining seasonal resilience whereas the other, a more stable, weaker and therefore limiting one is overlapping by longer term resilience. Whereas Acid Neutralization Capacity mostly determines the sustainability an increasing rate limitation of buffering intensity correlates with the performance of resilience in the form of an inversed quantity-intensity function. This means, in the domain of highly available capacity the system works close to equilibrium and with loss of capacity removes from this point with increasing resilience until the system is totally exploited and succession to an another system possessing lower potentials starts.

Consequently, it is interesting to qualify the soil resources and non-biotic resilience factors. Assuming kinetic reactions under conditions of the inherent openness of developing ecosystems, the median of $\mathrm{pH}$ frequency distribution is useful to mark the equilibrium domain of defined buffer reactions by the values of their equilibrium constants. In the present case there is an amazing match of year wise oscillation between hydrogen hydrogencarbonate/dihydro-carbonic acid buffering (pKs 6.4) and another system directed to the system carbonate/hydrogen-carbonate buffering in the range of $\mathrm{pH} 8$. During phases of strong acidification (see Fig. 21) mostly the faster system is active (see Fig. 22). The lower $\mathrm{pH}$ of solution in the less sandy part of the soil is dominated by buffering of humic substance and harder reaction of aluminium species (not shown here, for more details see Schimming et al., 2011). With regard of ecosystem potentials and resilience already Ulrich (1985) in the times of first perception of forest damage and the onset of cause-effect analyses, had been concerned about the critical ratios between persistent nutrient losses from acidified ecosystems and soil pools which indicate long-term existent potentials or sustainability.

In addition, from a number of monitoring programs, for instance Level II of ICP-Forests (ICP-Forests, http://icp-forests.net, 2015), data in an adequate temporal resolution should be available for assessing mass actions and resilience in the integrative quality aspect of resilience by use of biogeochemical data sets in particular on soil solution. For the future it would be challenging to develop a perspective to identify the critical state of ecosystems in the domain of transition away from stability towards resilience performance respectively sensitive or critical reaction of an ecosystem. Such concepts are also able for contributing to the progress of ecosystem theories (Jørgensen, 2012; Müller and Leupelt, 1998),

Case study: Resilient groundwater dynamics in the Uckermark landscape (UCK)

G. Lischeid, C. Merz, R. Dannowski

The Leibniz Centre for Agricultural Landscape Research (ZALF) has been performing a comprehensive monitoring program in the Quillow catchment since the late 1990s. The Quillow catchment is located in the Uckermark region in the Federal State of Brandenburg, about $100 \mathrm{~km}$ north of Berlin, and close to the town of Prenzlau (Mirschel et al., 2006; Fischer and Schröder, 2014). It is one of the LTER-D sites as well as part of the TERENO initiative (http:// teodoor.icg.kfa-juelich.de/overview-en?set_language=en). It is part of the Pleistocene landscape of Northeast Germany with several $100 \mathrm{~m}$ thick unconsolidated sediments. The Quillow is a tributary to the Ucker river which discharges to the Baltic Sea. Elevation varies between $14 \mathrm{~m}$ a.s.l. in the east and $157 \mathrm{~m}$ a.s.l. in the west. Annual mean air temperature $1961-1990$ was $7.8^{\circ} \mathrm{C}$, annual precipitation $508 \mathrm{~mm}$. Loamy soils predominate. Agricultural land use comprises about $74 \%$ of the area, where arable fields clearly prevail.

Based on daily meteorological data from the Dedelow research station, daily potential evapotranspiration was calculated according to Allen et al. (1998). This approach assumes a short grass cover with optimum water availability. Thus it does neither account for higher evapotranspiration of larger plants nor for limited water availability in dry periods. Precipitation was corrected for measuring errors according to Richter (1995), which is essential for hydrological analyses. The difference between daily precipitation and potential evapotranspiration is called the climatic water balance. Summing up daily values of the climatic water balance yields the cumulative climatic water balance which is often used as a rough approximation of the change of soil water storage or groundwater level dynamics.

The hydrogeological structure is characterized by a local upper, unconfined aquifer underlain by regional confined aquifer systems. The two aquifers are separated by a 5-15 m thick till layer of Weichselian age. Groundwater level has been continuously monitored in four groundwater wells using pressure transducers and data loggers. The wells are located within $3 \mathrm{~km}$ distance from each other, about $8-11 \mathrm{~km}$ west of the Dedelow research station. One well is located in the immediate vicinity of the Quillow River and screened at $16-18 \mathrm{~m}$ depth below surface. Here the till layer crops out and the deeper groundwater discharges into the Quillow River under unconfined conditions. The other three wells are screened in the covered deeper aquifer between 15 and $24 \mathrm{~m}$ below surface.

Automatic readings at daily intervals reveal a pronounced highfrequency dynamics which is a typical characteristic for confined aquifers (Lischeid et al., 2010). Besides, deep groundwater dynamics was more damped compared to that in the uppermost aquifer. In addition, groundwater head dynamics exhibited clear seasonal patterns. Groundwater recharge usually is restricted to the dormant season when evapotranspiration is close to zero, resulting in a clear increase during the winter season. During the growing season, groundwater head usually decreases because groundwater discharge to the receiving streams continues whereas groundwater 


\section{Frequencies}
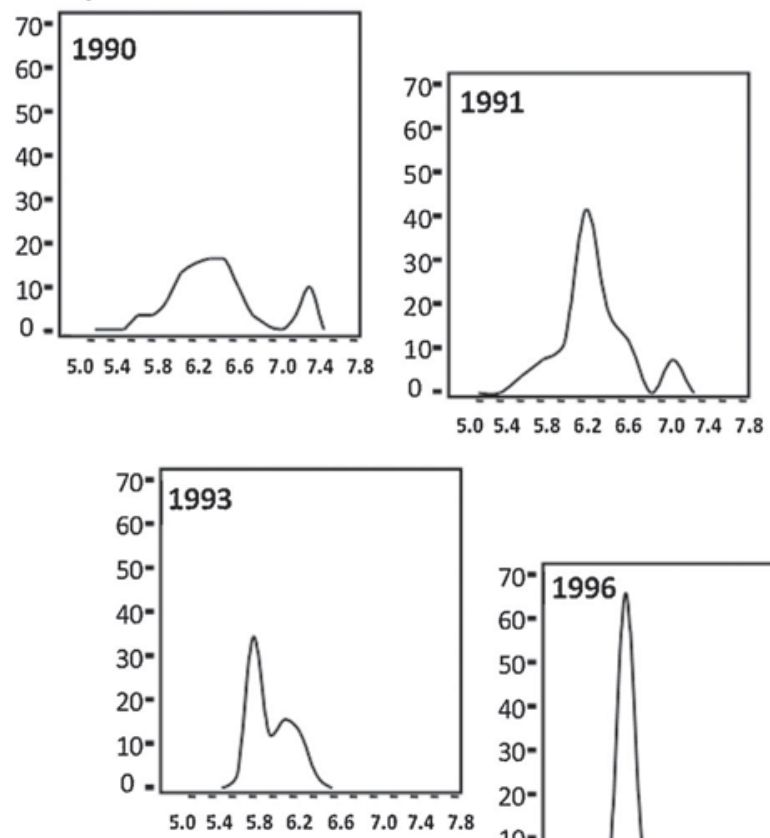

$\begin{array}{lllllllll}5.4 & 5.8 & 6.2 & 6.6 & 7.0 & 7.4 & 7.8\end{array}$
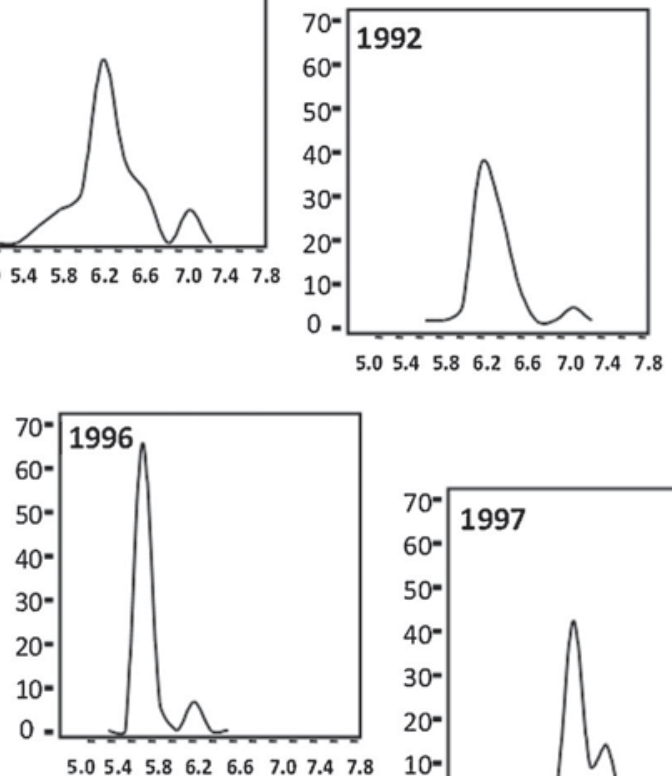

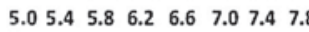
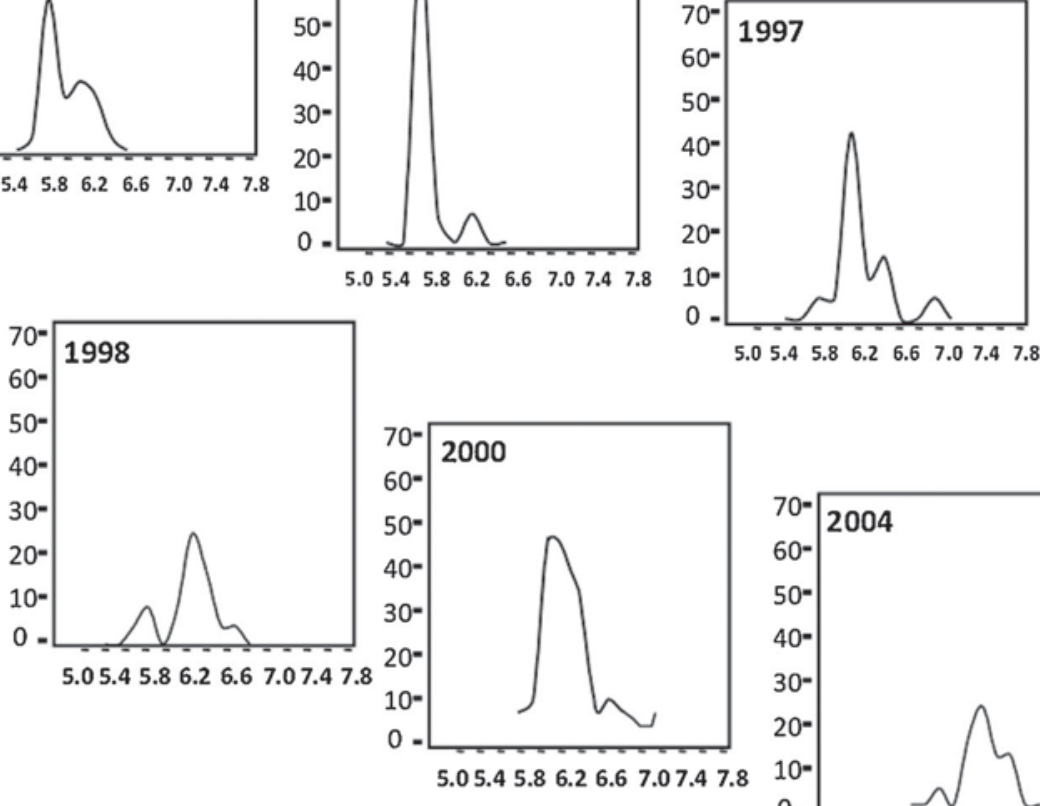

$\mathrm{pH}$

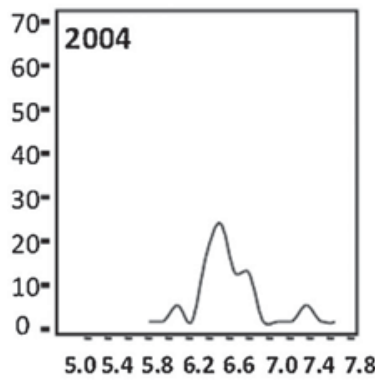

Fig. 22. Frequency distributions of pH values in soil solution selected according to changing trend in the 1989-2008 period under conditions of low Acid Neutralization Capacity and limited buffering in a mineral subsoil horizon (150 cm soil depth).

recharge ceases. Besides these short-term dynamics groundwater head exhibited a clear decrease from 2002 through 2006 at all wells. In 2007 there was hardly any summer depression visible, resulting in an increase until spring 2008, followed by another two-year decrease until 2010. Groundwater head increased thereafter until 2013 and started to decrease again then.

As mentioned above, the cumulative water balance is used as a rough surrogate for deep seepage fluxes that eventually reach the groundwater system, thus supposed to be the primary driver of the groundwater head dynamics. In fact the cumulative climatic water balance exhibited a clear decrease until 2006 and a two-years increase thereafter, synchronous to the decrease of groundwater heads. However, recovery from low values is less pronounced compared to that of the groundwater head. In addition, the increase of groundwater head between 2010 and 2012 is not at all mimicked by the cumulative climatic water balance (Fig. 23).

Thus the latter seems to systematically underestimate the recovery potential of groundwater head dynamics. It has to be kept in mind that the climatic water balance is a fairly simplified approach to assess seepage flux to groundwater. One of the main shortcomings is that it does not account for the adaptation of plants to water stress and limited water availability in dry soils during dry periods. Both effects combine to reduce water losses to the atmosphere and further decrease of groundwater heads. Thus the combined plants-soil-groundwater system can be considered as a resilient system that can buffer low precipitation and high evaporation as long as it does not exceed a certain range.

Indication for resilience in megafaunal communities from the deep Artic Ocean? (HAU)

(M. Bergmann \& T. Soltwedel)

The unique long-term record gathered at the Long-Term Ecological Research (LTER) site HAUSGARTEN since 1999 is one of the 

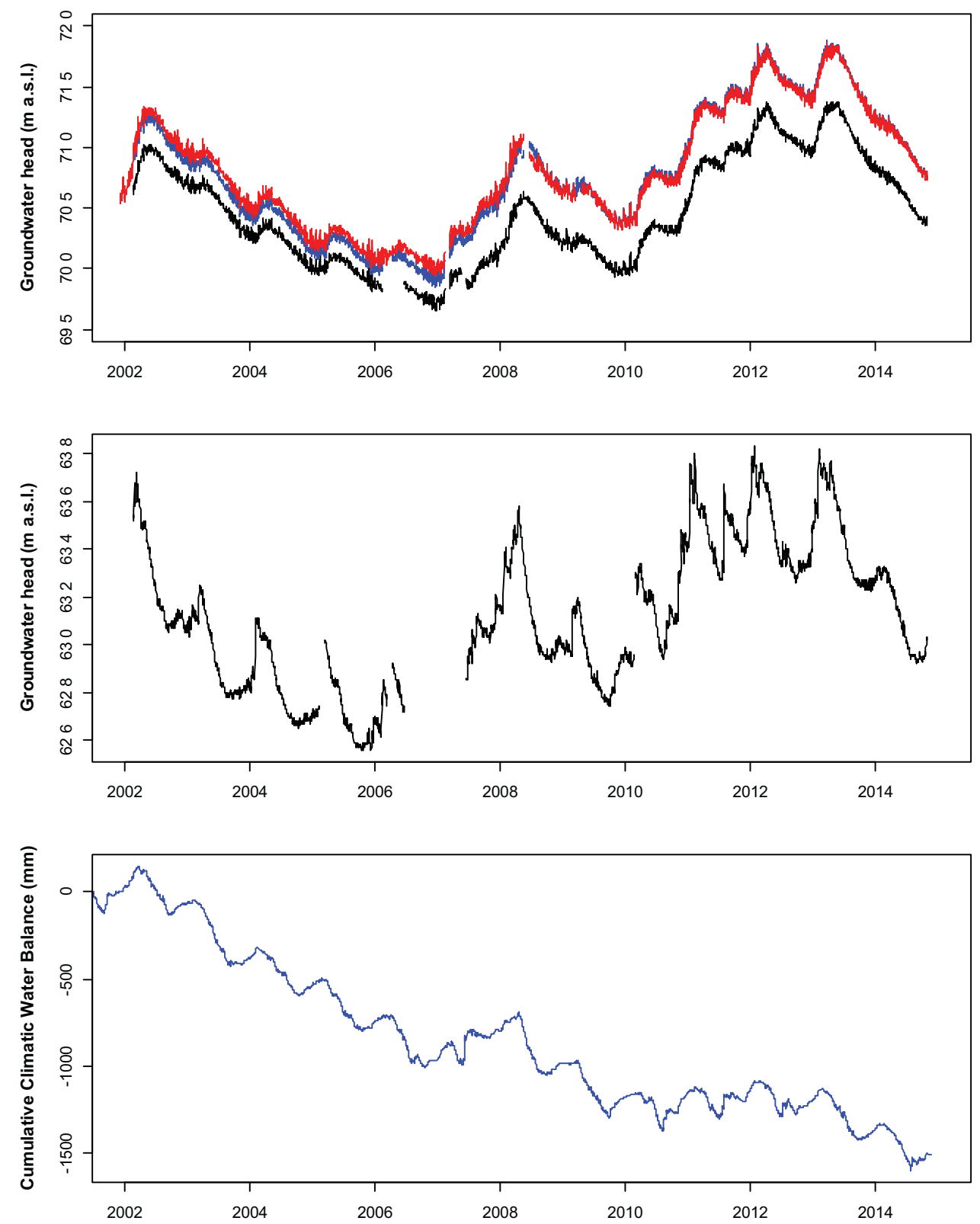

Fig. 23. Time series of groundwater head in the deep aquifer (upper panel), shallow aquifer (intermediate panel), and cumulative climatic water balance (lower panel) 2002-2014.

best data sets available to study Arctic marine ecosystem dynamics. The observatory is located in the Fram Strait, which represents one of the most sensitive regions with regard to Climate Change in the North (Soltwedel et al., 2005). Multi-disciplinary time-series studies at the central HAUSGARTEN station (2500 m water depth) between 2002 and 2011 showed some interesting trends, which might indicate long-term resilience in megafaunal communities from the deep Arctic Ocean.

Epibenthic megafauna are defined as organisms larger than $1 \mathrm{~cm}$ and inhabiting the sediment-water interface (Bergmann et al., 2011). Despite their comparatively low abundances, megafauna play an important role in the benthic community, exerting significant effects on bioturbation (Wheatcroft et al., 1989), carbon budgeting (Piepenburg, 2005), oxygen consumption (Piepenburg et al., 1995), and sediment composition (Gallucci et al., 2008a). Megafauna make up a significant proportion of the arctic deep-sea biomass (Piepenburg et al., 1995) and enhance habitat complexity, both by virtue of their physical structure (Beaulieu, 2001) and by modifying the sediment texture with burrows, tracks, and traces (Wheatcroft et al., 1989; Kaufmann and Smith, 1997). Through predation, megafauna control the population dynamics of smaller-sized prey and may therefore significantly shape benthic community composition (Feder and Pearson, 1988; Sardá et al., 1998; Gallucci et al., 2008b).

Still images to assess temporal variations in megafaunal densities and composition were collected using a vertically facing towed camera system, the Ocean Floor Observation System (OFOS). A detailed technical description of the system is given in Meyer et al. (2013). The OFOS was repeatedly towed at $\sim 0.5$ knots and $\sim 1.5 \mathrm{~m}$ altitude along a set transect $(\sim 2$ nautical miles) at the central HAUSGARTEN site (approximately 2400-2600 m water depth) in summer 2002, 2004, 2007, and 2011. All images retrieved for this study were analyzed and stored using the openaccess image analysis programme and database BIIGLE (Bio-Image Indexing, Graphic Labelling, and Exploration; https://ani.cebitec. uni-bielefeld.de/biigle; Ontrup et al., 2009). The 15 largest and 


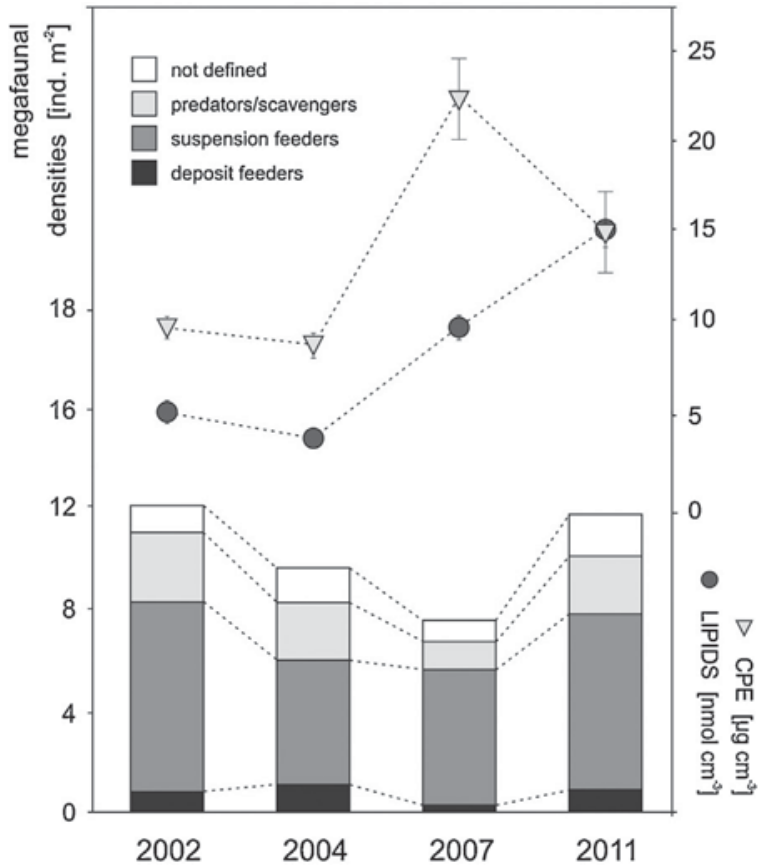

Fig. 24. Mean megafaunal densities (ind. $\mathrm{m}^{-2}$ ) in different feeding groups and biogenic sediment compounds indicating organic matter input (chloroplastic pigment equivalents, CPE; grey triangles) as well as total microbial biomass (phospholipid concentrations, LIPIDS; black circles) in surface sediments at the central HAUSGARTEN station (2500 m water depth) between 2002 and 2011.

consistently recognized taxa were grouped into broad feeding types (cf. Bergmann et al., 2009), namely suspension feeders, deposit feeders, predators/scavengers and others, to assess changes in the trophic structure.

Benthic environmental parameters were determined from sediment samples obtained by a multiple corer during annual research expeditions between 2002 and 2011 aboard the RVs "Polarstern" and "Maria S. Merian". The top $5 \mathrm{~cm}$ of the sediment were sub-sampled using plastic syringes $(1 \mathrm{~cm}$ in diameter) with cutoff anterior ends and analyzed for different biogenic sediment compounds: Sediment-bound chloroplastic pigments, indicating phytodetritial matter (i.e. food availability) at the seafloor, were extracted in $90 \%$ acetone and measured with a Turner fluorometer according to Shuman and Lorenzen (1975). Phospholipid concentrations, indicating the total microbial biomass in surface sediments, were determined following the method of Findlay et al. (1989), with slight modifications as described in Boetius and Lochte (1994).

The analysis of different biogenic sediment compounds indicating organic matter input from phytodetritus sedimentation, and microbial biomass as another potential food source for higher benthic organisms, revealed comparably low and even slightly decreasing levels between 2002 and 2004 (Fig. 24). Following the effects of a warm-water anomaly on primary production between 2005 and 2008 (Beszczynska-Möller et al., 2012) and a subsequent increased flux of organic matter to the seafloor (Lalande et al., 2013), values for both parameters increased significantly in 2007 (Fig. 24), and remained at a higher level (Soltwedel, unpubl. data).

The analysis of OFOS footage taken between 2002 and 2007 indicated a significant gradual decrease in total megafaunal densities (Bergmann et al., 2011), most probably in response to overall low or continuously decreasing food availability. Although suspension feeder densities also decreased, deposit feeder and predator/scavenger densities declined to such an extent that suspension feeders accounted for almost $100 \%$ of the megafauna in 2007. It could thus be argued that the trophic diversity at the central HAUSGARTEN site constantly decreased in those years (Bergmann et al., 2011). After 2007, however, total megafaunal densities increased again approaching 2002-levels in 2011 (Fig. 24). Total densities from 2002 and 2011 were significantly different from those in 2004 and 2007 (Kruskall-Wallis test and pairwise Mann-Whitney comparisons using a Bonferroni correction of $p=0.00001$.

Given the well-known time lag in the reaction of megafauna to increased food availability at the deep seafloor (Ruhl, 2007), it is not surprising that megafaunal densities were found to be lowest in 2007 , although food availability had already improved considerably in the same year. However, significantly higher food availability at the deep seafloor since then obviously brought megafaunal densities at the central HAUSGARTEN site back to original values as found in 2002. What is more, the densities of most feeding types reached 2002-levels in 2011. All these data may indicate that - after a time period of starvation - the system had gone "back to normal", which could be considered resilient behaviour.

Unusual weather conditions may challenge stability and resilienc of nutrient-poor lakes: The example of Lake Stechlin in summer 2011. (STE)

(P. Kasprzak, J. Padisák, G. Selmeczy, T. Shatwell)

Climate warming in combination with exceptional weather events might impact the structure and function of freshwater ecosystems in many ways (Scheffer and Carpenter, 2003; Jentsch et al., 2007; Scheffer et al., 2012; Wang et al., 2012). Slowly changing external forces like eutrophication along with climate warming may undermine the resilience of lakes. Thus, if a given lake has been brought to the limit of its resilience by these two factors, it may only take a strong-enough weather event to push it into another dynamic equilibrium from where it may converge to an alternative persistent state. Thus, studies on exceptional weather events are particularly informative because they provide insight into the mechanisms leading to structural and functional changes. Nevertheless, since stochastic and rare events are hard to predict, only few examples have been well documented (Conroy et al., 2011; Jennings et al., 2012; Klug et al., 2012; Beaver et al., 2013; Vachon and del Giorgio, 2014).

In July 2011, an unusually powerful low pressure area passed across northern Germany causing some of the most extreme wind speeds, air temperature drops and rainfall intensities since 1958. Within two weeks, this storm had significantly changed the trophic appearance of oligo-mesotrophic Lake Stechlin (latitude $53^{\circ} 10^{\prime} \mathrm{N}$, longitude $13^{\circ} 02^{\prime} \mathrm{E}$, area $4.23 \mathrm{~km}^{2}$, mean depth $22.3 \mathrm{~m}$, maximum depth $69.5 \mathrm{~m}$, volume $98.7 \times 10^{6} \mathrm{~m}^{3}$, for more information see Koschel and Adams, 2003). This triggered a clear cascade of effects, the most remarkable of which was a drastic decrease of transparency, which reached its minimum since the beginning of records in 1970.

Air pressure dropped suddenly from $1004 \mathrm{hPa}$ to $994 \mathrm{hPa}$ between July-16 and July-17, and remained low until July-24. On July-22 the wind speed spiked to $7.7 \mathrm{~m} \mathrm{~s}^{-1}$, almost four times the annual mean, and daily mean air temperature declined from $19.0^{\circ} \mathrm{C}$ to $14.0^{\circ} \mathrm{C}$. Finally, daily sums of sunshine dropped from $11.5 \mathrm{~h}$ on July-19 to zero on July-21 and remained low during the following four days.

As a result of the high wind speed, low air temperature, and little sunshine, both water temperature and the stratification pattern of the lake underwent significant alterations. Surface temperature decreased suddenly by almost $2.4^{\circ} \mathrm{C}$, and the mixed layer deepened from 7 to $8 \mathrm{~m}$. 
This dispersed the pointed deep chlorophyll maximum (DCM), which had formed by July-14, throughout the mixed layer (Fig. 25). Furthermore, the chlorophyll- $a$ profile collected on July-27 suggests an increase in biomass of the former DCM-phytoplankton now growing in the mixed layer (Fig. 26). The phytoplankton community was largely dominated by filamentous cyanobacteria (especially Dolichospermum circinalis) with a small amount of cryptophytes.

This result is supported by ${ }^{14} \mathrm{C}$-planktonic primary production measurements (Fig. 26): whereas the production rate on July-14 was around $50 \mathrm{mg} \mathrm{C} \mathrm{m}^{-3} \mathrm{~d}^{-1}$, it had significantly increased by July27 to a maximum rate of $239 \mathrm{mg} \mathrm{C} \mathrm{m}^{-3} \mathrm{~d}^{-1}$ at $2.5 \mathrm{~m}$.

The intense photosynthesis of phytoplankton increased the $\mathrm{pH}$ from 8.5 to 8.9 between June-22 and July-27. Consequently, the calcite saturation index increased from 3.3 to 7.7 and the calcite concentration increased from 0.13 to $1.1 \mathrm{mg} \mathrm{L}^{-1} \mathrm{CaCO}_{3}$ between July-14 and July-27. Due to the high concentration of diffractive calcite crystals, Secchi-transparency dropped by roughly $4 \mathrm{~m}$ and the euphotic depth by approximately $8 \mathrm{~m}$.

Long-term observations of transparency and total phosphorus concentration showed that the mixed layer and deep water of the lake were differently impacted (Fig. 27). Water clarity in 2011 (measured as Secchi transparency) was the lowest since 1970. Readings increased again in subsequent years, but overall transparency has clearly been decreasing since 2003 . TP values at $40 / 60 \mathrm{~m}$ depth increased slightly after 1996, but jumped sharply in 2011, and
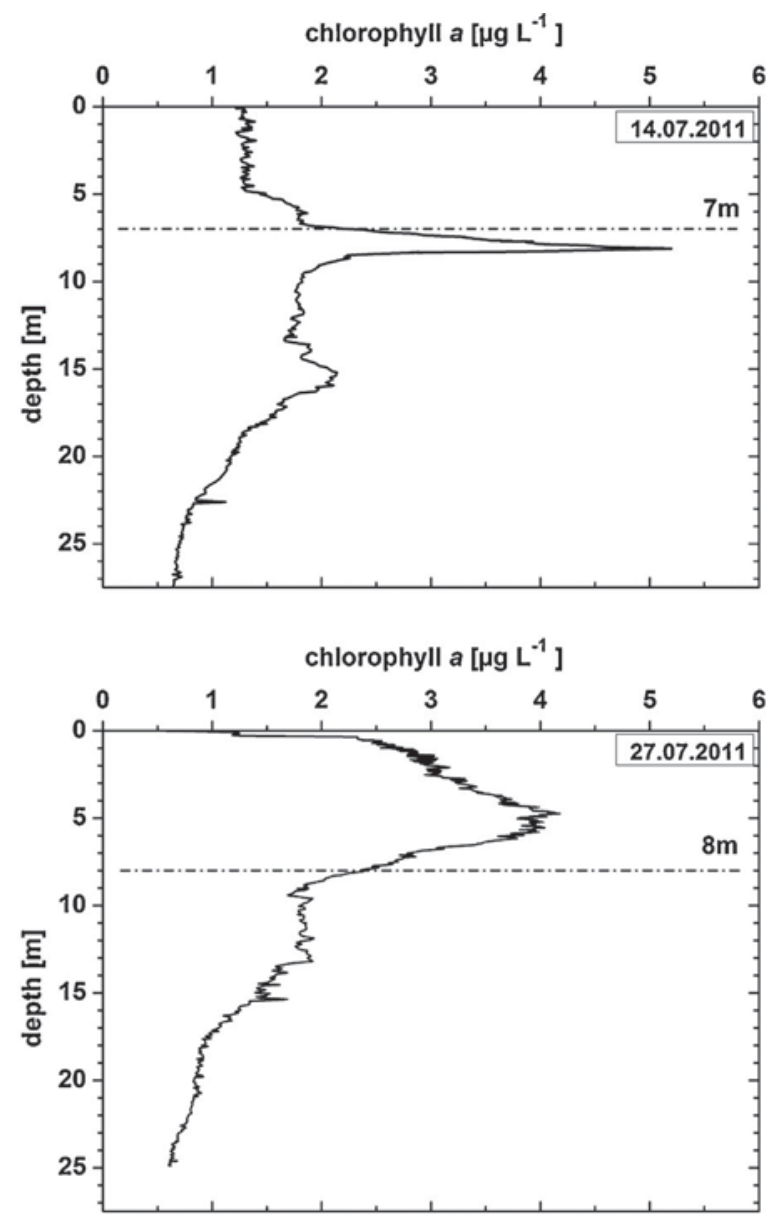

Fig. 25. Vertical profiles of chla-concentration of total phytoplankton (in situ fluorescence). By 14.07.2011 a spike-like deep chlorophyll maximum had developed close to the boundary of the mixed layer (upper panel). Two weeks later, the algae were entrained in the mixed layer as a consequence of the extended mixed layer (lower panel).
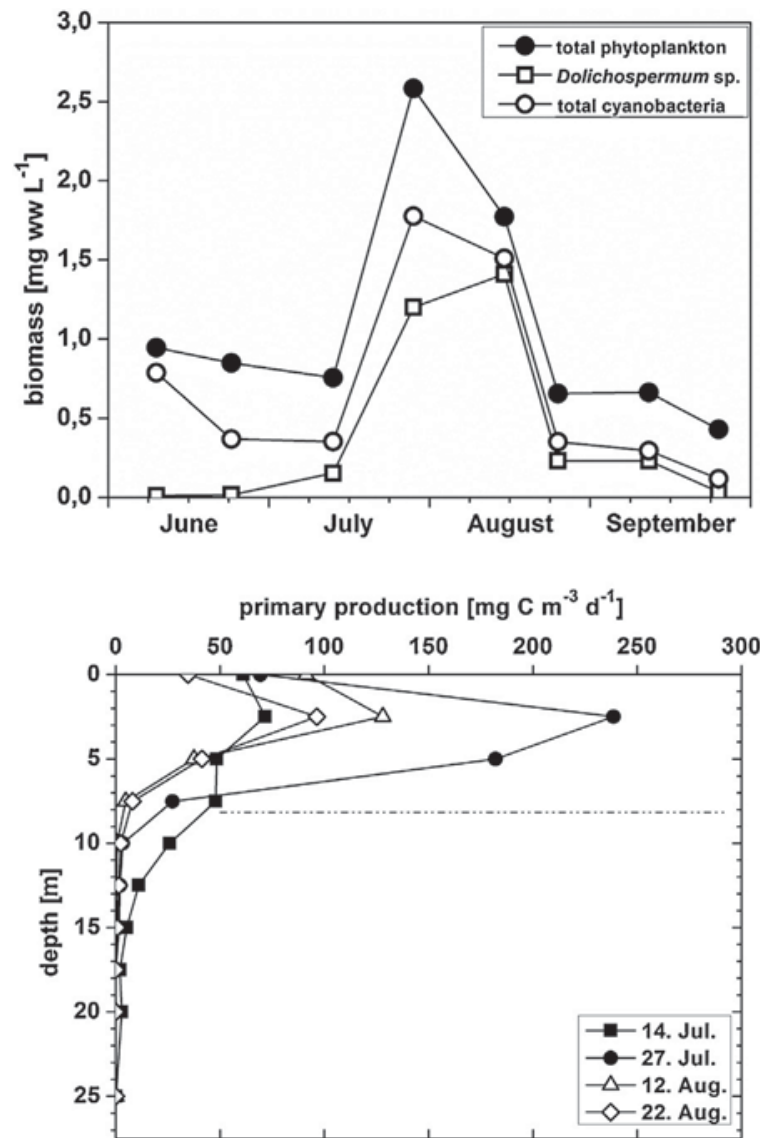

Fig. 26. Time-series of phytoplankton biomass (upper panel) and vertical profiles of planktonic primary production (lower panel). During the second half of July phytoplankton biomass increased from $0.8 \mathrm{mg} \mathrm{ww} \mathrm{L}^{-1}$ to $2.6 \mathrm{mg} \mathrm{ww} \mathrm{L}^{-1}$; the bulk being contributed by filamentous cyanobacteria. Daily production rate significantly increased from 14.07. to 27.07.2011, showed a peak-like pattern and for the most part was restricted to the mixed layer (horizontal line).

continued to increase in subsequent years (with the exception of 2013), albeit more slowly. TP values at $10 \mathrm{~m}$ depth remained unchanged.

We conclude that the immediate reason for the recorded changes was undoubtedly an unusual ("extreme") weather situation caused by the passage of the cold front of a deep-pressure area. Although the specific mechanisms involved are hard to disentangle, we suppose that climate warming ultimately promoted these alterations through long-term gradual nutrient enrichment and oxygen depletion in the deep water of the lake (Shatwell et al., 2012). Significant changes like this might be considered a regime shift as suggested by Carpenter (2003). Since water clarity subsequently returned to previous values, the lake may have been both resilient and stable enough to return to the initial state (attractor, sensu Scheffer et al., 1993), rather than shift into a new stable state of higher productivity (Scheffer and Carpenter, 2003). However, if lakes with similar characteristics to Lake Stechlin approach the transition between oligotrophic and mesotrophic conditions, they might respond to extreme weather events because of weakened stability and resilience. Under these circumstances it obviously requires little more than a storm to cause drastic changes in water quality. However, in hard-water lakes calcite precipitation in concert with phosphorus co-precipitation and sequestration in the sediment is apparently the key-mechanism to substantially support resilience (Koschel et al., 1983) (Table 5). 

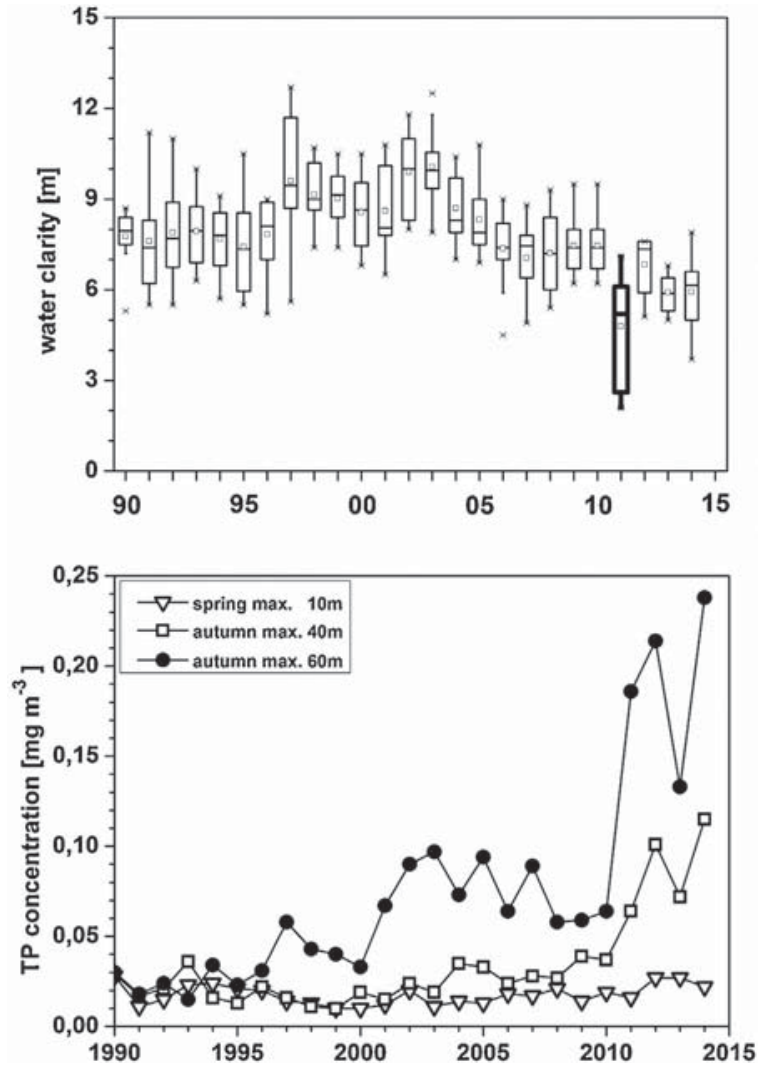

Fig. 27. Long-term records of water clarity (Secchi depth, May-October, upper panel) and maximum total phosphorus concentration at 10/40/60 m depth (TP, lower panel) in Lake Stechlin at the beginning in spring and towards the end of thermal stratification in Autumn. Water clarity was exceptionally low in 2011 but increased again in subsequent years, although the overall decreasing trend since 2003 is obvious. While TP values in 40/60 m after 1996 slightly increased, a major increment was recorded between 2010/11; and with the exception of 2013 continued up to now though to a lesser extent. TP values at $10 \mathrm{~m}$ remained unchanged.

Table 5

Topographical, morphological, hydrological, and chemical characteristics of Lake Stechlin (Koschel and Adams, 2003).

\begin{tabular}{|c|c|c|}
\hline Surface area & $\mathrm{km}^{2}$ & 4.23 \\
\hline Volume & $10^{6} \mathrm{~m}^{2}$ & 98.7 \\
\hline Maximum depth & $\mathrm{m}$ & 69.5 \\
\hline Mean depth & $\mathrm{m}$ & 23.3 \\
\hline Shoreline length & $\mathrm{km}$ & 16.1 \\
\hline Drainage basin & $\mathrm{km}^{2}$ & 12.6 \\
\hline Forested area in drainage basin & $\%$ & 95 \\
\hline Water body retention time & years & $>40$ \\
\hline Soluble reactive phosphorus ${ }^{\mathrm{a}}$ & $\mu \mathrm{g} / \mathrm{L}$ & 2.5 \\
\hline Total phosphorus ${ }^{\mathrm{a}}$ & $\mu \mathrm{g} / \mathrm{L}$ & 13.8 \\
\hline $\mathrm{NO}_{3}-\mathrm{N}^{\mathrm{a}}$ & $\mu \mathrm{g} / \mathrm{L}$ & 21.3 \\
\hline $\mathrm{NH}_{4}-\mathrm{N}^{\mathrm{a}}$ & $\mu \mathrm{g} / \mathrm{L}$ & 39.9 \\
\hline Planktonic primary production ${ }^{b}$ & $\mathrm{~g} \mathrm{C} \mathrm{m}^{-2}$ year $^{-1}$ & 121 \\
\hline External phosphorus load ${ }^{c}$ & $\mathrm{~g} \mathrm{Pm}^{-2}$ year $^{-1}$ & $0.04-0.06$ \\
\hline
\end{tabular}

a Average 1992-2000, 0-10 m.

b Average 1992-2000.

c $1970-2000$.

\section{Discussion}

\subsection{Challenges concerning the case study analyses}

The case studies described in the previous chapter have not been primarily conducted in order to investigate the resilience concept. Much more the prevailing studies were adopted after a call for examples within the German LTER community. That was motivated by the demand to develop a collection of empirical data and threshold characteristics, as formulated e.g. by Walker and Meyers (2004), who state that "research into this topic has been hampered by a lack of empirical data" and who have been motivated to found a resilience threshold data base. ${ }^{12}$ Due to this motivation and the individualized selection criteria, the arrangement of case studies may suffer from a biased sample and some conceptual restrictions, there may be weaknesses referring to the comparability of the cases and to the uncertainties emerging from the multitude of applied methodologies.

The authors are aware that a serious resilience investigation or stability analysis should fulfil the information demands listed in Table 6. We hope that the preceding texts (incl. Table 2 in the introduction) can provide the respective information and that the following paragraphs can be used to complement the picture. This list also shows how intricate serious resilience assessments are, because besides several methodological challenges, a very good knowledge of the discussed disturbance, the investigated system and its dynamics is necessary.

\subsection{Comparison of the case studies and attempts for classification}

Although the case studies are related to quite different disturbances and ecosystems, it is possible to characterize and compare the site conditions and to look for similarities, common problems and obvious distinctions. Figs. 28 and 29 provide some additional information referring to the focal questions of Carpenter et al. (2001): "Resilience of what to what"? Which is the observed system and what is the disturbance? The first figure lists some characteristics of the case studies' disturbances: Apparently they can be settled on a long gradient of typical temporal scales. Starting with the vegetation development during the Holocene, the spectrum of pertubations ends with rather short weather extremes. All of these disturbances are operating at distinct temporal scales, which are related to spatial extends automatically, underlining the panarchy approach of Gundersson and Holling (2002) and several landscape related approaches (e.g. Cumming, 2011a; Plieninger and Bieling, 2012): While climatic modifications are affecting the whole globe, e.g. deposition patterns are on a subcontinental scale or pest outbreaks are regional characteristics, and single weather events often occur locally, only.

Looking at the consequences of these disturbances, Fig. 29 documents some features of the ecosystem reactions for all described sites. It can be seen that in several cases (from SER to HES) a regime shift could be observed, while the lower sites in the figure (UCK to STE) can be characterized by mainly resilient dynamics. These are the case studies with the lowest lengths of data sets. May be this arrangement is a simple consequence of the probability to find resilient behaviour: if we concentrate on short-term processes there may be less destabilizing situations appearing than by looking at longer time intervals. Thus, the occurrence of regime shifts might be a function of the temporal probability of significant impulses. But it might also be possible that by concentrating on short-term dynamics, important process scales cannot be considered, and finally this observation can be used to verify the assignment of resilience to short-term phenomena, while adaptability refers to longer developmental pathways (see Fig. 29).

Interestingly, several case studies can be assigned to both categories, because some attributes are able to return to the former basin of attraction within the approximate return times (resilience), while other indicators clearly show that the ecosystem is moving towards a new steady state (regime shift). These sites demonstrate the significance of indicator selection as well as the problem of

\footnotetext{
12 http://www.resalliance.org/index.php/thresholds_database.
} 
Table 6

Required information to characterize studies on ecosystem resilience, following Gigon and Grimm (1997), Müller et al. (2010a,b) and Burkhard et al. (2011).

\begin{tabular}{|c|c|c|}
\hline Information class & Information demand & Examples \\
\hline System definition & $\begin{array}{l}\text { Which is the investigated degree of organization? } \\
\text { Which are the structural attributes of the system definition? } \\
\text { Which are the functional attributes of the system definition? } \\
\text { Which is the spatial scale applied? } \\
\text { Which is the temporal scale applied? }\end{array}$ & $\begin{array}{l}\text { Social-ecological system, ecosystem, food web, etc. } \\
\text { Species composition, soil constituents, demography, etc. } \\
\text { Water budgets, energy or matter flows, etc. } \\
\text { Watershed, landscape, ecosystem, etc. } \\
100 \text { years, } 10 \text { years, } 1 \text { year, etc. }\end{array}$ \\
\hline Disturbance definition & $\begin{array}{l}\text { Which is the focal disturbance? } \\
\text { How is the disturbance quantified? } \\
\text { Which are the threshold values of the disturbance used? }\end{array}$ & $\begin{array}{l}\text { Climate, land use, pollution, invasions, etc. } \\
\text { Change in temperature, input, output, etc. } \\
2 \text { degrees limits, critical loads, toxic concentrations, etc. }\end{array}$ \\
\hline Reaction definition & $\begin{array}{l}\text { Which indicators are used to characterize the system's behaviour? } \\
\text { Which is the investigated stability feature? } \\
\text { How is the "identity" of the system defined? } \\
\text { How is the domain of attraction characterized? } \\
\text { Which is the typical dynamics of the reference system? } \\
\text { How is the system behaviour quantified? }\end{array}$ & $\begin{array}{l}\text { Ecosystem integrity, ecosystem services, etc. } \\
\text { Resilience, resistance, buffer capacity, etc. } \\
\text { Similarity with a historical reference state, etc. } \\
\text { Variability of indicators within thresholds, etc. } \\
\text { Annual dynamics, tides, } 10 \text {.year cycles, etc. } \\
\text { Dynamics of indicator values, etc. }\end{array}$ \\
\hline $\begin{array}{l}\text { Study targets and } \\
\text { purpose }\end{array}$ & $\begin{array}{l}\text { Which uncertainties have to be considered? } \\
\text { Which is the normative loading of the analysis? } \\
\text { Which is the inherent target of the management measure? }\end{array}$ & $\begin{array}{l}\text { System definition, indicator measurements, etc. } \\
\text { Study for ecosystem restoration, flood protection, etc. } \\
\text { Optimize resilience, optimize adaptability, etc. }\end{array}$ \\
\hline
\end{tabular}

\begin{tabular}{|c|c|c|c|c|c|c|c|c|}
\hline \multicolumn{2}{|c|}{ Focal time scales } & \multirow{2}{*}{$\begin{array}{c}\begin{array}{c}\text { Millen- } \\
\text { nium }\end{array} \\
1000 \mathrm{a}\end{array}$} & \multirow{2}{*}{$\begin{array}{r}\begin{array}{r}\text { Cen- } \\
\text { tury }\end{array} \\
100 \text { a }\end{array}$} & \multirow{2}{*}{$\begin{array}{l}\begin{array}{r}\text { De- } \\
\text { cade }\end{array} \\
10 \mathrm{a}\end{array}$} & \multirow{2}{*}{$\begin{array}{l}\text { Year } \\
1 \mathbf{1 a}\end{array}$} & \multirow{2}{*}{$\begin{array}{l}\text { Month } \\
1 / 12 \mathrm{a}\end{array}$} & \multirow{2}{*}{$\begin{array}{r}\text { Week } \\
1 / 52 \text { a }\end{array}$} & \multirow{2}{*}{$\begin{array}{r}\text { Day } \\
1 / 365 \text { a }\end{array}$} \\
\hline $\begin{array}{l}\text { Focal } \\
\text { disturbances }\end{array}$ & $\begin{array}{l}\text { Exemplary } \\
\text { case } \\
\text { studies }\end{array}$ & & & & & & & \\
\hline $\begin{array}{l}\text { Holocene } \\
\text { climate } \\
\text { change }\end{array}$ & SER & & & & & \multirow{6}{*}{\multicolumn{2}{|c|}{$\begin{array}{l}\text { Mainly } \\
\text { long-term } \\
\text { changes } \\
\text { of constraints } \\
\rightarrow \text { Slow } \\
\text { modifications }\end{array}$}} & \\
\hline $\begin{array}{l}\text { Land use } \\
\text { intensification }\end{array}$ & $\begin{array}{l}\text { BOR, HES } \\
\text { SER }\end{array}$ & & & & & & & \\
\hline $\begin{array}{l}\text { Recent } \\
\text { climate } \\
\text { change }\end{array}$ & $\begin{array}{l}\text { NOR, UCK, } \\
\text { HES, STE }\end{array}$ & & & & & & & \\
\hline $\begin{array}{l}\text { Eutrophicatio } \\
n\end{array}$ & $\begin{array}{l}\text { DZB, HES, } \\
\text { STE, LAK }\end{array}$ & & & & & & & \\
\hline $\begin{array}{l}\text { Acid } \\
\text { deposition }\end{array}$ & $\begin{array}{l}\text { BHS, BAY } \\
\text { LAN }\end{array}$ & & & & & & & \\
\hline Alien species & $\begin{array}{l}\text { HES, WAT } \\
\text { SER }\end{array}$ & & & & & & & \\
\hline $\begin{array}{l}\text { Pest } \\
\text { outbreaks }\end{array}$ & BAY & \multirow{6}{*}{\multicolumn{2}{|c|}{$\begin{array}{l}\text { Mainly } \\
\text { short-term } \\
\text { consequences } \\
\text { of constraints } \\
\text { dynamics or } \\
\text { short-term } \\
\text { events } \\
\rightarrow \text { Triggers of } \\
\text { change }\end{array}$}} & & & & & \\
\hline $\begin{array}{l}\text { Climate } \\
\text { oscillations }\end{array}$ & $\begin{array}{l}\text { NOR, } \\
\text { HAU, }\end{array}$ & & & & & & & \\
\hline $\begin{array}{l}\text { Deforestation, } \\
\text { drainage }\end{array}$ & BOR & & & & & & & \\
\hline Drought & $\begin{array}{l}\text { BHS, } \\
\text { UCK }\end{array}$ & & & & & & & \\
\hline $\begin{array}{l}\text { Ice scraping, } \\
\text { ice covers }\end{array}$ & $\begin{array}{l}\text { DZB, WAT, } \\
\text { NOR }\end{array}$ & & & & & & & \\
\hline $\begin{array}{l}\text { Rare weather } \\
\text { events }\end{array}$ & $\begin{array}{l}\text { BAY, STE, } \\
\text { NOR }\end{array}$ & & & & & & & \\
\hline
\end{tabular}

Fig. 28. Some temporal characteristics of the dominating disturbances in the case studies (symbolized by the abbreviations from Table 2).

assessing resilience at the multifactorial ecosystem level: several different indicators are necessary and therefore several different results must be expected.

Furthermore, at least two case studies (DZB, NOR) seem to be governed by multistable dynamics. Here, the structural shaping (community composition) strongly depends on certain shortterm conditions (winter temperature, ice-dynamics) which can hardly be foreseen. Nevertheless these exterior factors trigger the developmental direction of the ecosystems year by year, whereby different community characteristics can be appearing with similar probabilities. These conditions can be found at the Darß-Zingst site with reference to the appearance of macrophytes and at the Norderney site considering macrozoobenthos communities. The third case of multistable dynamics seems to occur in the soil systems of the Bornhöved beech forest. Here, different soil chemical buffer systems with typical capacities and temporal extents are regulating 


\begin{tabular}{|c|c|c|c|c|c|c|c|c|}
\hline \multirow[t]{2}{*}{ Case study } & \multirow{2}{*}{$\begin{array}{l}\text { Main } \\
\text { disturbances }\end{array}$} & \multicolumn{6}{|c|}{ Features of ecosystem dynamics } & \multirow[t]{2}{*}{ Comments } \\
\hline & & 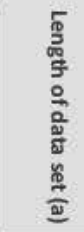 & 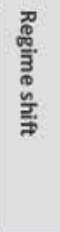 & 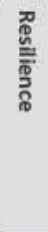 & 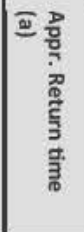 & 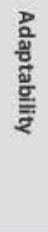 & 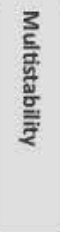 & \\
\hline $\begin{array}{l}\text { Serrahn } \\
\text { (SER) }\end{array}$ & $\begin{array}{l}\text { Holocene climate } \\
\text { Human land use }\end{array}$ & 10000 & & & 1000 & & - & Very slow vegetation change \\
\hline $\begin{array}{l}\text { Lake Constance } \\
\text { (LAK) }\end{array}$ & Eutrophication & 43 & & & 60 & & - & $\begin{array}{l}\text { Partial slow recovery of } \\
\text { chemistry, not plankton }\end{array}$ \\
\hline $\begin{array}{l}\text { Darß-Zingster } \\
\text { Bodden Chain } \\
\text { (DZB) }\end{array}$ & $\begin{array}{l}\text { Eutrophication } \\
\text { Ice dynamics }\end{array}$ & 55 & & - & - & - & & $\begin{array}{l}\text { Ice-triggered bistability of } \\
\text { subsequent lagoons }\end{array}$ \\
\hline $\begin{array}{l}\text { Bornhöved } \\
\text { wetlands } \\
\text { (BOR) }\end{array}$ & $\begin{array}{l}\text { Agroproduction } \\
\text { Land use change }\end{array}$ & $\begin{array}{c}60 \\
(25)^{*}\end{array}$ & & & $-/ 60$ & & - & $\begin{array}{l}\text { Differences } b \text {. structural and } \\
\text { functional resilience }\end{array}$ \\
\hline $\begin{array}{l}\text { Lange Bramke } \\
\text { (LAN) }\end{array}$ & Acid deposition & $\begin{array}{l}60 \\
35^{*}\end{array}$ & & & 100 & - & - & $\begin{array}{l}\text { Acidification confounded by } \\
\text { eutrophication }\end{array}$ \\
\hline $\begin{array}{l}\text { Bayerischer Wald } \\
\text { (BAY) }\end{array}$ & $\begin{array}{l}\text { Deposition } \\
\text { Pest outbreaks }\end{array}$ & 35 & & & -125 & & - & $\begin{array}{l}\text { Differences } b \text {. trees, fauna and } \\
\text { trait aspects }\end{array}$ \\
\hline $\begin{array}{l}\text { Norderney } \\
\text { (NOR) }\end{array}$ & $\begin{array}{l}\text { Climate changes } \\
\text { Winter } \\
\text { conditions }\end{array}$ & 35 & & & - & & & $\begin{array}{l}\text { NAO triggered distinction of } \\
\text { macrofauna community }\end{array}$ \\
\hline $\begin{array}{l}\text { Wadden Sea } \\
\text { (WAT) }\end{array}$ & $\begin{array}{l}\text { Climate events } \\
\text { Winter } \\
\text { conditions }\end{array}$ & 35 & & - & 10 & - & - & $\begin{array}{l}\text { Mussel populations finding } \\
\text { new attractor states }\end{array}$ \\
\hline $\begin{array}{l}\text { Hesse rivers } \\
\text { (HES) }\end{array}$ & $\begin{array}{l}\text { Alien species } \\
\text { Eutrophication }\end{array}$ & 25 & & - & - & & - & $\begin{array}{l}\text { Shifts in community structures } \\
\text { due to alien fish }\end{array}$ \\
\hline $\begin{array}{l}\text { Uckermark } \\
\text { (UCK) }\end{array}$ & $\begin{array}{l}\text { Climate change } \\
\text { Precipitation }\end{array}$ & 15 & - & & $<6$ & - & - & $\begin{array}{l}\text { Groundwater dynamics \& } \\
\text { hydrologicaladaptation }\end{array}$ \\
\hline $\begin{array}{l}\text { HAUSGARTEN } \\
\text { (HAU) }\end{array}$ & $\begin{array}{l}\text { Climate change } \\
\text { Anomalies }\end{array}$ & 15 & - & & 1 & - & - & $\begin{array}{l}\text { Resilient develop-ment in the } \\
\text { deep sea }\end{array}$ \\
\hline $\begin{array}{l}\text { Bornhöved soil } \\
\text { (BHS) }\end{array}$ & $\begin{array}{l}\text { Depostion } \\
\text { Summer } \\
\text { conditions }\end{array}$ & $\begin{array}{c}14 \\
(25)^{*}\end{array}$ & - & & 2 & - & & $\begin{array}{l}\text { Soil pH shifting over different } \\
\text { buffer systems }\end{array}$ \\
\hline $\begin{array}{l}\text { Stechlinsee } \\
\text { (STE) }\end{array}$ & $\begin{array}{l}\text { Weather event } \\
\text { Eutrophication }\end{array}$ & 0,1 & - & & $<1$ & - & - & $\begin{array}{l}\text { Deep pressure event causes } \\
\text { resilient changes }\end{array}$ \\
\hline
\end{tabular}

Fig. 29. Some characteristics of the dynamics in the case studies. *(number of years of empirical data at the site).

the soil $\mathrm{pH}$ which is changing constantly within certain limits. A similar shift may have occurred at Lange Bramke, but this process was largely completed before the observation started.

Finally, in a restricted number of cases the conditions of adaptability can be fulfilled; here the integrity of the systems is rising again after the disturbance, following the orientor functions (see Fig. 29). This reaction type has been assigned to the sequence of complexifying successions of beech forests at the Serrahn site (SER), the community development in Lake Constance (LAK), to some developmental pathways of the Bornhöved wetlands (BOR), to the Norderney site (NOR) and to the rivers in Hesse (HES), which in some cases are developing in a functional orientor manner, although the actors are invasive species.

There are several possibilities to group the case studies. One of them is related to the age of the ecosystems. Referring to their dynamics, the systems with the highest variability seem to be the young and relatively flat aquatic habitats, such as the DarßZingst-Bodden Chain (DZB), the Norderney sediments (NOR), or the Wadden sea areas in Lower Saxony (WAT). These ecosystems are exposed to extreme dynamics of external factors, be it the tide dynamics, floods, winds or ice covers. Therefore, these ecosystems can hardly create durable internal structures by self-organized processes. Only at the periphery, e.g. reed belts can arise, which support a long life-time duration of the internal systems components.

On the other side, Lake Constance (LAK), Lake Stechlin (STE), or Hausgarten (HAU) seem to be aquatic ecosystems with a longer possible duration of structure building processes. This can e.g. be seen by comparing the sediment characteristics of the aquatic case studies. All of them demonstrate relatively high buffer capacities with reference to the chosen disturbances.

All terrestrial ecosystems can much better evolve in visible successional processes, and therefore mainly these ecosystems show the characteristics of adaptability. Due to the long life spans of terrestrial vegetation we can e.g. observe the long-time development of the Serrahn beech forest(SER), the slow regeneration of the Bornhöved wetlands (BOR), the reduction of sulfur concentrations in the soils of the Lange Bramke catchment (LAN), the spruce regrowth in the Bayerischer Wald (BAY), the pH variability of the soil solution of 
Table 7

Distinction of resilience assessments referring to different attributes of the same sites.

\begin{tabular}{|c|c|c|}
\hline Case study & Resilient variable & Non-resilient variable \\
\hline Serrahn (SER) & Early pristine forests & Modern beech forests \\
\hline Lake Constance (LAK) & P concentrations & Community composition \\
\hline $\begin{array}{l}\text { Darß-Zingst Bodden } \\
\text { Chain (DZB) }\end{array}$ & Water chemistry & Macrophytobenthos \\
\hline $\begin{array}{l}\text { Bornhöved wetlands } \\
\text { (BOR) }\end{array}$ & Wetland structure & Wetland function \\
\hline Lange Bramke (LAN) & Sulfur fluxes & Exchangeable base cations \\
\hline $\begin{array}{l}\text { Bayerischer Wald } \\
\text { (BAY) }\end{array}$ & Spruce stands & Spider compositions \\
\hline Norderney (NOR) & Sediments & Macrofauna \\
\hline Wadden Sea (WAT) & $\begin{array}{l}\text { Blue mussel pop. } \\
\text { (old) }\end{array}$ & Blue mussel pop. (new) \\
\hline Hesse rivers (HES) & Water chemistry & Fish composition \\
\hline $\begin{array}{l}\text { Bornhöved Beech } \\
\text { Forest (BHF) }\end{array}$ & $\begin{array}{l}\text { Short term } \\
\text { concentrations }\end{array}$ & Long-term concentrations \\
\hline Uckermark (UCK) & Groundwater & Climatic water balance \\
\hline Hausgarten (HAU) & Megafauna densities & Community composition \\
\hline Lake Stechlin (STE) & Water clarity & Phosphorus concentration \\
\hline
\end{tabular}

the Bornhöved beech forest (BHF), or the high adaptive capacity of vegetation in a development of steadily increasing drought in the Uckermark (UCK).

\subsection{Methodological challenges}

From a methodological viewpoint, the empirical site dynamics are demonstrating the importance of the selection of indicators for resilience assessment: in most case studies, several indicators have been used to demonstrate the dynamics of the investigated ecosystems. As a consequence of the specific disturbances and the respective site conditions, most of these attributes behave differently. Therefore the valuation of resilience can be quite different although the same systems and the same disturbances are considered. The results are ambiguous depending on the reference variables used, provoking arbitrary outcomes of the analyses. Table 7 shows these situations: if we use one indicator variable, the result will be "resilient"; and if we apply another attribute, a "non-resilient" situation will be concluded.

Of course, the resulting valuation can be correct, if the selected variable is the only target parameter of an investigation. But regrettably in most applied cases, the target value is ecosystem condition, which cannot be represented by one indicator alone. Therefore, multifactorial, holistic indicator sets are necessary for a determination of ecosystem resilience, including structural factors (e.g. species composition, soil or sediment characteristics, regional distribution schemes) as well as functional criteria (e.g. indicators for water, matter and energy budgets). Several examples for respective indicator proposals can be found in the literature, such as terrestrial integrity indicator sets (e.g. Müller, 2005; Stoll et al., 2015), the index of biological integrity (IBI: e.g. Andreasen et al., 2001; Borja et al., 2009; Pinto et al., 2009), ecosystem health indicators (Joergensen et al., 2010) or ecosystem service indicator sets (e.g. Stoll et al., 2015; Kandziora et al., 2013; Haines-Young et al., 2012; Grunewald and Bastian, 2012). For sure it will be interesting to apply these and similar indicator sets for resilience assessment, i.e. the interesting questions of system identity (which is the reference state?), threshold definition (which is the width of the basin of attraction?) and the concentration on one disturbance (how to exclude accompanying disturbances?) will arise for all factors used. In fact these points open a broad range of additional methodological and conceptual problems.

As a resilience assessment should be based on the dynamic behaviour of ecosystems or ecosystem elements and as we could see in some examples before (Figs. 28 and 29), the temporal dimensions of the disturbance play an important role. Under steady state conditions, the configuration of the system is creating a self-organized hierarchy, in which the slowly changing variables (holons) are producing constraints for those processes which operate with higher frequencies due to specific signal filtering mechanisms (O’Neill et al., 1986; Müller, 1992; Gundersson and Holling, 2002). If the ecosystem is moving towards destruction, instabilities and risks occur (see Joergensen et al., 2007) that are generally correlated with a hierarchical break: the system of constraints can no more provide the regulation mechanisms which keep it within the steady state-related attractor basin. Then the fast variables can determine the fate of the overall entity.

In the demonstrated data sets we can find several examples for these considerations: The long-term changes from Fig. 28 (e.g. climate change, protracted land use intensification, steady eutrophication, oligotrophication) are situated in long-term periods, slowly increasing the "brittleness" (Gundersson and Holling, 2002) of the ecosystem. Rare events with extremely short disturbance durations then are the points of departure for destructive dynamics.

All case studies have been carried out in living ecosystems, which for sure are influenced by several drivers and pressures. Therefore, the buffering mechanisms have to cope with a multitude of inputs and external influences. In this context indirect effects can play a major role as well as cumulative or delocalized effects. The interplay of different disturbances finally leads to the emergence of tipping points, which result in long-term loadings of slow variables which are strongly amplified by short-term events of fast variables, leading to a sudden change of the basin of attraction's shape. Table 8 provides some examples for these combinations of long-term loadings that produce a continuous, cumulating strain, and short-term effects, which in some cases are responsible for the overall fate of the whole system. Again, it would be short-sighted to assign the effects to the single second (fast) variable alone. It may provoke the moment of the fast breakdown, the abrupt creative destruction of an ecosystem, but the final cause often is based on the slow effects of long-term pressures.

\subsection{Conceptual challenges of the resilience approach}

The analyses and aggregations of the case studies also illuminate some conceptual difficulties which are related to the resilience concept. These problems already start with the basic definition of resilience which seems to undergo interesting adaptive dynamics. While in the early definitions (e.g. Holling, 1973, see Table 1) the target system clearly was an ecological entity, the object of resilience has changed via social-ecological systems (Gundersson and Holling, 2002) and ecosystem service providers (Deutsch et al., 2003) to social systems themselves (Folke et al., 2003). Of course the determination of the object is an extremely significant processual step: tt makes a difference to value the composition of a biotic community or the value of provided ecosystem services, i.e. because in the latter case it is not important which organisms have been responsible for the service production. And of course a society can be resilient although the ecological systems are strongly disturbed, if the respective indicators are clearly reflecting the selected indicandum. From a conservative viewpoint, this expansion of topical objects of resilience from ecological to human systems is correlated with an increasing terminological diffusion and a weakening of the term's relevance.

Another aspect of the scientific resilience-development can be found in the meaning of "return" or "maintenance". Originally resilience was used to describe the ability of a system to remain in the original basin of attraction after a disturbance, to return to the old stage. By investigating the more modern definitions, new aspects are added: for instance, there is the capacity for self-organization (Walker et al., 2002) that is a dynamic, actually 
Table 8

Some examples for combinations of disturbances operating at different scales.

\begin{tabular}{|c|c|c|c|}
\hline Case study & Slow variable & Fast variable & Time step difference \\
\hline Serrahn (SER) & Holocene climate change & Land use intensity, Short-term climate shift & Millennia \langle\rangle Century \\
\hline Lake Constance (LAK) & Oligotrophication & & \\
\hline Darß-Zingst Bodden Chain (DZB) & Oligotrophication & Ice scraping & Century \langle\rangle Days \\
\hline Bornhöved wetlands (BOR) & Fertilization & Drainage & Decades \langle\rangle Weeks \\
\hline Lange Bramke (LAN) & Overall acid deposition & Sulfur deposition & Century $\langle>$ Decades \\
\hline Bayerischer Wald (BAY) & Overall acid deposition & Bark beetle outbreak & Decades \langle\rangle Weeks \\
\hline Norderney (NOR) & Climate change & Cold winters & Decades \langle\rangle Weeks \\
\hline Wadden Sea (WAT) & Eutrophication & Ice cover & Decades \langle\rangle Days \\
\hline Hesse rivers (HES) & Oligotrophication & Invasions & Decades \langle\rangle Months \\
\hline Bornhöved Beech Forest (BHF) & Deposition dynamics & Precipitation & Decades \langle\rangle Weeks \\
\hline Uckermark (UCK) & Climate change & Local weather & Decades \langle\rangle Weeks \\
\hline Hausgarten (HAU) & Climate change & Food availability & Decades \langle\rangle Months \\
\hline Lake Stechlin (STE) & Sediment dynamics & Weather event & Decades \langle\rangle Days \\
\hline
\end{tabular}

non-resilient process, we can find the ability to learn and adapt, to support progress and to continue to develop (Folke et al., 2003), and even the transformation into new regimes can be called "resilience" (CGIAR, 2014). Although it is interesting to observe long-tendencies in science, these changes show that in some cases the contents of the concept is being turned into the opposite of the original meaning, another point that might move the idea of resilience into a confusing approach.

Additional difficulty was arising when the attempt was made to characterize resilience by quantitative indicators. The results in Tables 28 and 29 show that it is rather uncomplicated to use Pimm's return time (1984) to represent the system's resilience capacities. But this reasonable methodology has been labelled engineering resilience (Gundersson and Holling, 2002) and it was suggested within the resilience alliance to better use the "ecological resilience", which shall be measured by the magnitude of a disturbance that the system can tolerate and still persist. Our case studies have shown that an exact quantification of this feature is hardly possible, because in nature always several disturbances are influencing the state of an ecosystem, and their specific effects are also a function of the respective singularity (tipping points) and the very specific constitution of the ecosystem at that point in time. Besides these problems of multi-disturbances and different classes of disturbance-interrelations, an exact quantification of ecological resilience with respect to one pressure only can only be carried out in experiments with increasing amounts of this single disturbance, such as pesticide - concentration intensifications. In this case it might also be possible to characterize resilience based upon a ration between the size of the disturbance and the time necessary to return to the initial state. Finally cumulative, delayed, delocalized and indirect effects hardly can be considered in such a respective experimental layout.

A further field of problems arises from the definition of the reference state which defines the original basin of attraction. The question is how to draw the limitations of a system's identity? As we have seen before, it is a difference to choose a structural or a functional item, it makes a difference to observe ecological or human-environmental systems and within these systems it makes a difference to choose a variable with high or low undisturbed variability. Some examples for a potentially related ambiguity are demonstrated in Table 2 . The results can differ totally in dependence of the indicators chosen. Therefore, it might be easier to work with the concept of resistance.

In spite of these problems, many papers and applications have shown, that the resilience analysis of ecological systems has been a steadily growing field of increasing knowledge and understanding and an area of intense transitions from science into policy. The resilience alliance has demonstrated how to constructively use systems approaches in management and how to apply metaphors to increase the comprehension of ecological structures, processes and organizations. There are several advantages and ecological milestones which have made resilience a topical approach in science and policy. The resilience approach has helped to analyze disturbances and to foster disturbance ecology, it has introduced the creative potential of breakdowns and it has bundled several concepts in ecology and environmental management.

But of course there are also some problems in the political and management application, two of them shall be discussed here. The first point is related to the distinction of helpful (desirable) and unhelpful (undesirable) resilience by Standish et al. (2014): resilience has a positive connotation if "helps to maintain a predisturbance ecosystem state so that it does not cross a threshold". The authors call resilience unhelpful if it "helps to maintain an ecosystem in a degraded state following a disturbance". This may be the case in damaged systems which have to be restored and should be developed instead of returned to the old state. In this context, resilience is a conservative conception which - in its roots - does not cover the aspect of development and which should not be linked with a value in itself.

The second point easily can be attached to the first item: the ability to return to a previous basin of attraction can be very high in simple systems which are not related to a longer historical developmental duration. On the other hand, the reestablishment of complex ecosystems after the same disturbance can be much harder and take much more time for recovery. Also the Resilience Alliance states that pioneer systems have a much higher resilience than mature systems. Therefore, a maximization of resilience would be related to a simplification of the respective ecosystems. But this measure would contradict most conceptions and valuations of nature protection: Systems with high diversity and connectivity have the highest status of preservation, but they comprise of a low degree of resilience. Therefore, a translation into policy should not be linked to resilience maximization but optimization and has to be checked from case to case.Furthermore, resilience in its pure sense is always connected to the past. Transferring the idea into management could mean to attempt to restore old structures wherever possible. On the other hand, looking at longer time scales ecosystems have always been dynamic systems, they have been developing all the time and therefore - in a provoking attitude - they can be generally classified to be un-resilient. Otherwise evolution would fail.

If we want to foster self-organized development, succession and orientor behaviour in the face of all the categories of recent global change, the ecosystems need transformations, and the focal question is not the avoidance of change but its direction. Therefore, the combination of resilience and adaptability (see Fig. 2) provides an interesting couple of dynamics: If we restrict the (helpful) role of resilience to smaller temporal scales, the consequences of disturbances can be evaluated by the return to the old conditions. This is a precondition for further development, whereby the rise of certain 
emergent ecosystem properties (orientors) can be used as an indicator for the dynamics of healthy ecosystems with a high degree of ecological integrity. Of course these points have also been adopted by many authors, who have enlarged the concept by the adaptive capacity which describes the systems behaviour after change. The realization of the need to complement resilience with dynamic approaches can also be found by once more observing the definitions and the significance of change in their foci in Table 1 . The difference to our distinctions (resilience vs. adaptability) in the introduction is placed in the distracting implementation of both (relative stability and change) in many resilience comprehensions. Here it might be advisable to stronger distinguish between these different features of ecosystem dynamics, especially as the concept is more and more applied in environmental management and policy.

\section{Conclusions}

In this article we have tried to use several long-term data sets to illuminate and investigate the concept of resilience in ecosystems. The joint experiment turned out to have a constructive outcome, underlining the extreme usefulness of long-term ecological research in contributing to theoretical questions and actual management conceptions.

Resilience was perceived as an interesting interdisciplinary, "tolerant" and elastic stability concept which is connected to many metaphorical ideas and illustrations and only to a small amount of quantitative descriptions. The results have made obvious that resilience analyses can easily suffer from arbitrary indicator selections and reference definitions. And it has become clear that the complexity of ecosystems strongly limits the capability to focus on the effects of one disturbing variable alone. Therefore, resilience investigations are demanding tasks with several methodological restrictions and high information demands which urgently have to be fulfilled.

Coming back to the initial questions from the introduction, the results can be summarized as follows: an exclusive resilient behaviour of ecosystems in the investigated long-term data sets was mainly found under the conditions of short-term disturbances, while over longer periods, adaptability comes into play and the efficiency of high-magnitude disturbances is rising: the longer the time series, the more changes could be observed.

Consequently, spatio-temporal scales play a major role in resilience analysis. Not only the ecosystem processes are operating in a spatio-temporal hierarchy, but also the disturbances can be characterized by special spatio-temporal characteristics. These scales are interlinked in the ecosystem which is receiving the inputs, and therefore the many disturbances are interacting here: long-term processes can produce cumulative impairments and indirect effects which are fostering degradations, thus the vulnerability of the ecosystem can be increased. If in that situation, short events with high potential magnitudes occur, the system has a high probability for non-resilient dynamics at these tipping points.

From a strategic viewpoint, there is a high demand to critically reprove and rethink the definitions of resilience used in the literature and in environmental politics, as meanwhile some modern comprehensions seem to explain the opposite of the original meaning of the term. Although it is nice to see that the word resilience provides a multitude of positive connotations, a strict delineation of the contents and a clear distinction between different classes of dynamics (e.g. resilience vs. adaptability) would be extremely helpful for a consistent environmental analysis and serious policy.

For a consistent resilience analysis several methodological requirements are formulated. For instance it is not trivial to exactly and intersubjectively define the "identity of the system" and the width of the attractor basin of the investigated ecosystem. There is a high potential of ambiguous determinations.

The case studies also have demonstrated that the results of a resilience valuation strongly depend on the selection of the applied indicators and the selection of a reference state. For both items, the development of systems-based indicator sets can be suggested, in order to avoid false information of the decision makers.

For many purposes, resilience can be used as a suitable management concept, as long as the "helpful" branch of resilience is considered. But for many purposes it cannot: the conception is basically limited to disturbance dynamics and their consequences; focusing on resilience, excludes the positive dynamics of adaptability or adaptive capacity and transformation. The consequences of successions are reducing resilience, at least from a formal and mathematical viewpoint, and thus simple ecosystems (pioneer systems) provide a higher degree of resilience than mature (highly complex and diverse systems) ones. As the latter entities are those areas with high ecological and biodiversity values, a strict management application of resilience or even a maximization of resilience should be observed with care, because such attitudes hinder selforganized development.

And in times of policies for sustainable development it might be more adequate to look into the future instead of taking the past configurations as a target, to foster development instead of return to former situations, to optimize adaptability and flexibility instead of supporting stagnation. Therefore, the communicating concepts should be considered stronger, of course with linkages to resilience, but they should not be hidden under the highly and happily accepted resilience term.

Therefore, we can close with the extremely resilient quotation of Heraclitus from Ephesius, who stated that one can never step into the same river because all the time new waters are streaming - panta rhei - everything is flowing and developing.

\section{Acknowledgements}

The authors wish to thank the guest editors of this issue for their tolerance referring to the unusual outline and form of this paper and the reviewers for their constructive remarks. The contributions of M. Küster, M. Schult and M. Theuerkauf were enabled by the projects ICLEA and TERENO of the Helmholtz Association.

\section{Appendix 1. Materials and Methods used for the case study: Fish assemblages in German rivers: Do we get back to historical reference conditions?}

Data on fish assemblages were extracted from the electrofishing databases provided by the German Federal State agencies Hessen-Forst, and Landesamt für Natur, Umwelt und Verbraucherschutz NRW, and thus cover the two Federal States of Hesse and Northrhine-Westphalia. Data before 1990 were scarce and therefore omitted from the analyses. The most recent samples available were from 2009. The dataset contains 6858 local fish community assessments from streams. A total of 62 fish species were differentiated (Table S1). Among them, 16 species are alien to Germany. One additional species, huchen (Hucho hucho), is native in the Danube catchment in Germany, but not in the catchments of the rivers Rhine and Weser to which this study was limited.

First, occurrence rates of alien fish species were calculated as the fraction of sites at which aliens occurred. Second, the relative abundance of alien species was calculated as the average fraction of individuals that these aliens contributed to a local fish assemblage. All statistical analyses were done using $R$ software version 2.9.1 (R Development Core Team, 2011). Temporal trends were analysed using linear and quadratic functions. Quadratic models were 
Table S1

List of species that were found in the 6858 local fish community assessments that were analyzed for this study.

\begin{tabular}{|c|c|c|}
\hline Species number & Latin species names & Nativeness \\
\hline 1 & Anguilla anguilla & Yes \\
\hline 2 & Cobitis taenia & Yes \\
\hline 3 & Misgurnus fossilis & Yes \\
\hline 4 & Misgurnus anguillicaudatus & No \\
\hline 5 & Abramis brama & Yes \\
\hline 6 & Alburnoides bipunctatus & Yes \\
\hline 7 & Alburnus alburnus & Yes \\
\hline 8 & Aspius aspius & Yes \\
\hline 9 & Barbus barbus & Yes \\
\hline 10 & Blicca bjoerkna & Yes \\
\hline 11 & Carassius carassius & Yes \\
\hline 12 & Carassius gibelio & Yes \\
\hline 13 & Carassius gibelio auratus & No \\
\hline 14 & Cyprinus carpio & Yes \\
\hline 15 & Gobio gobio & Yes \\
\hline 16 & Leucaspius delineatus & Yes \\
\hline 17 & Leuciscus idus & Yes \\
\hline 18 & Leuciscus leuciscus & Yes \\
\hline 19 & Phoxinus phoxinus & Yes \\
\hline 20 & Pseudochondrostoma nasus & Yes \\
\hline 21 & Pseudorasbora parva & No \\
\hline 22 & Rhodeus amarus & Yes \\
\hline 23 & Romanogobio albipinnatus & Yes \\
\hline 24 & Rutilus rutilus & Yes \\
\hline 25 & Scardinius erythrophthalmus & Yes \\
\hline 26 & Squalius cephalus & Yes \\
\hline 27 & Tinca tinca & Yes \\
\hline 28 & Vimba vimba & Yes \\
\hline 29 & Ctenopharyngodon idella & No \\
\hline 30 & Hypophthalmichthys molitrix & No \\
\hline 31 & Barbatula barbatula & Yes \\
\hline 32 & Esox lucius & Yes \\
\hline 33 & Lota lota & Yes \\
\hline 34 & Gasterosteus aculeatus & Yes \\
\hline 35 & Pungitius pungitius & Yes \\
\hline 36 & Lepomis gibbosus & No \\
\hline 37 & Gymnocephalus cernuua & Yes \\
\hline 38 & Perca fluviatilis & Yes \\
\hline 39 & Sander lucioperca & Yes \\
\hline 40 & Neogobius kessleri & No \\
\hline 41 & Neogobius melanostomus & No \\
\hline 42 & Neogobius fluviatilis & No \\
\hline 43 & Proterorhinus semilunaris & No \\
\hline 44 & Lampetra fluviatilis & Yes \\
\hline 45 & Lampetra planeri & Yes \\
\hline 46 & Petromyzon marinus & Yes \\
\hline 47 & Platichthys flesus & Yes \\
\hline 48 & Hucho hucho & $\mathrm{No}^{\mathrm{a}}$ \\
\hline 49 & Oncorhynchus mykiss & No \\
\hline 50 & Salmo salar & Yes \\
\hline 51 & Salmo trutta fario & Yes \\
\hline 52 & Salmo trutta lacustris & Yes \\
\hline 53 & Salmo trutta trutta & Yes \\
\hline 54 & Salvelinus alpinus & Yes \\
\hline 55 & Salvelinus fontinalis & No \\
\hline 56 & Salvelinus namaycush & No \\
\hline 57 & Thymallus thymallus & Yes \\
\hline 58 & Cottus gobio & Yes \\
\hline 59 & Silurus glanis & Yes \\
\hline 60 & Ameiurus melas & No \\
\hline 61 & Ameiurus nebulosus & No \\
\hline 62 & Poecilia reticulata & No \\
\hline
\end{tabular}

a Species is native only in the Danube catchment in Germany, but this catchment was not considered in this study.

only retained when the quadratic function provided a significantly better fit than the linear model. Both occurrence rates and relative abundance data were arcsine-square root-transformed.

To compare the ecological species traits of native and alien species, principal component analysis (PCA) with the $R$ package "FactoMineR" (Husson et al., 2015) was used. Data on ecological species traits were extracted from the "freshwaterecology.info"trait database (Schmidt-Kloiber and Hering, 2015). Information
Table S2

List of ecological species traits that were used to characterize native and alien species.

\begin{tabular}{|c|c|c|}
\hline Species trait & Trait levels & Definition \\
\hline Migration & $\begin{array}{l}\text { dia } \\
\text { pot } \\
\text { nom }\end{array}$ & $\begin{array}{l}\text { Diadrom } \\
\text { Potamodrom } \\
\text { No migration }\end{array}$ \\
\hline $\begin{array}{l}\text { Life } \\
\text { style }\end{array}$ & $\begin{array}{l}\text { pel } \\
\text { ben } \\
\text { dem }\end{array}$ & $\begin{array}{l}\text { Pelagic } \\
\text { Bentho-pelagic } \\
\text { Demersal }\end{array}$ \\
\hline Rheophily & $\begin{array}{l}\text { rhe } \\
\text { lim } \\
\text { eur }\end{array}$ & $\begin{array}{l}\text { Rheophilic } \\
\text { Limnophilic } \\
\text { Eurytopic }\end{array}$ \\
\hline $\begin{array}{l}\text { Feeding } \\
\text { habitat }\end{array}$ & $\begin{array}{l}\text { f_ben } \\
\text { f_pel }\end{array}$ & $\begin{array}{l}\text { Bottom feeder } \\
\text { Pelagic feeder }\end{array}$ \\
\hline Feeding diet & $\begin{array}{l}\text { inv } \\
\text { pis } \\
\text { phy } \\
\text { omn } \\
\text { inp } \\
\text { fil }\end{array}$ & $\begin{array}{l}\text { Invertivorous } \\
\text { Piscivorous } \\
\text { Phytophagous } \\
\text { Omnivorous } \\
\text { Inverti-piscivorous } \\
\text { Filter-feeding }\end{array}$ \\
\hline $\begin{array}{l}\text { Life span } \\
\text { (years) }\end{array}$ & $\begin{array}{l}\text { ls1 } \\
\text { ls2 } \\
\text { ls3 }\end{array}$ & $\begin{array}{l}<8 \\
8-15 \\
>15\end{array}$ \\
\hline $\begin{array}{l}\text { Body length } \\
(\mathrm{cm})\end{array}$ & $\begin{array}{l}\text { bl1 } \\
\text { bl2 } \\
\text { bl3 }\end{array}$ & $\begin{array}{l}<20 \\
20-39 \\
>39\end{array}$ \\
\hline $\begin{array}{l}\text { Shape factor (ratio } \\
\text { body length to body } \\
\text { height) }\end{array}$ & $\begin{array}{l}\text { sh1 } \\
\text { sh2 } \\
\text { sh3 } \\
\text { sh4 }\end{array}$ & $\begin{array}{l}<4.35 \\
4.35-4.78 \\
4.78-5.6 \\
>5.6\end{array}$ \\
\hline $\begin{array}{l}\text { Swimming factor (ratio height of } \\
\text { caudal peduncle to body height) }\end{array}$ & $\begin{array}{l}\text { sw1 } \\
\text { sw2 } \\
\text { sw3 }\end{array}$ & $\begin{array}{l}<0.38 \\
0.38-0.43 \\
>0.43\end{array}$ \\
\hline $\begin{array}{l}\text { Female maturity } \\
\text { (years) }\end{array}$ & $\begin{array}{l}\text { ma1 } \\
\text { ma2 } \\
\text { ma3 } \\
\text { ma4 } \\
\text { ma5 }\end{array}$ & $\begin{array}{l}<2 \\
2-3 \\
3-4 \\
4-5 \\
>5\end{array}$ \\
\hline Reproduction habitat & $\begin{array}{l}\text { phy } \\
\text { lit } \\
\text { pli } \\
\text { psa } \\
\text { ost } \\
\text { spe } \\
\text { viv } \\
\text { mar }\end{array}$ & $\begin{array}{l}\text { Phytophilic } \\
\text { Litophilic } \\
\text { Phyto-litophilic } \\
\text { Psammophilic } \\
\text { Ostracophilic } \\
\text { Speleophilic } \\
\text { Viviparous } \\
\text { Marine }\end{array}$ \\
\hline Spawn time & $\begin{array}{l}\text { st1 } \\
\text { st2 }\end{array}$ & $\begin{array}{l}\text { Once per year } \\
\text { Several times per year }\end{array}$ \\
\hline $\begin{array}{l}\text { Fecundity } \\
\text { (no. oocytes) }\end{array}$ & $\begin{array}{l}\text { fe1 } \\
\text { fe2 } \\
\text { fe3 }\end{array}$ & $\begin{array}{l}<55000 \\
55,000-60,000 \\
>60,000\end{array}$ \\
\hline $\begin{array}{l}\text { Egg diameter } \\
(\mathrm{mm})\end{array}$ & $\begin{array}{l}\text { ed1 } \\
\text { ed2 } \\
\text { ed3 }\end{array}$ & $\begin{array}{l}<1.3 \\
1.3-2 \\
>2\end{array}$ \\
\hline Parental care & $\begin{array}{l}\text { npc } \\
\text { npy } \\
\text { npn }\end{array}$ & $\begin{array}{l}\text { No parental care } \\
\text { Nest or egg hide with } \\
\text { parental protection } \\
\text { Nest or egg hide } \\
\text { without parental } \\
\text { protection }\end{array}$ \\
\hline
\end{tabular}

was updated and gaps were filled using supplemental literature (Nehring, 2005; Kottelat and Freyhof, 2007; Wiesner et al., 2010; Borcherding et al., 2011; Froese and Pauly, 2014; CABI, 2015). The full list of traits and the trait levels that were differentiated are given in Table S2. The factor "nativeness" of fish species was used as a supplemental categorical variable in the analysis. 


\section{References}

Adam, T.C., Schmitt, R.J., Holbrook, S.J., Brooks, A.J., Edmunds, P.J., Carpenter, R.C., Bernardi, G., 2011. Herbivory, connectivity, and ecosystem resilience: response of a coral reef to a large-scale perturbation. PLoS ONE 6 (8), e23717.

Alewell, C., Manderscheid, B., Meesenburg, H., Bittersohl, J., 2000. Is acidification still an ecological threat? Nature 407, 856-857.

Allen, R.G., Pereira, L.S., Raes, D., Smith, M., 1998. Crop evapotranspiration - Guideines for computing crop water requirements. FAO Irrigation and drainage paper 56. FAO - Food and Agriculture Organization of the United Nations, Rome.

Andreasen, J.K., O'Neill, R.V., Noss, R., Slosser, N.C., 2001. Considerations for the development of a terrestrial index of ecological integrity. Ecol. Indic. 1(1), 21-35.

Barbieri, A., Simona, M., 2001. Trophic evolution of Lake Lugano related to externa load reduction: Changes in phosphorus and nitrogen as well as oxygen balance and biological parameters. Lakes Reserv. Res. Manag. 6, 37-47, http://dx.doi.org/ 10.1046/j.1440-1770.2001.00120.x.

Bässler, C., 2008. Climate change - trend of the air temperature in the Bavarian Forest. Silva Gabretta 14, 1-18.

Bässler, C., Müller, J., Hothorn, T., Kneib, T., Badeck, F., Dziock, F., 2009. Estimation of the extinction risk for high montane species as a consequence of global warming and assessment of their suitability as cross-taxon indicators. Ecol. Indic. 10 341-352.

Bässler, C., Hothorn, T., Brandl, B., Müller, J., 2013. Insects overshoot the expected upslope shift caused by climate warming. PLOS ONE 8, e65842.

Beaver, J.R., Casamatta, D.A., East, T.L., Havens, K.E., Rodusky, A.J., James, R.T., Tausz, C.E., Buccier, K.M., 2013. Extreme weather events influence the phytoplankton community structure in a large lowland subtropical lake (Lake Okeechobee, Florida, USA). Hydrobiologia 709, 213-226.

Beudert, B., Bässler, C., Thorn, S., Noss, R., Schröder, B., Dieffenbach-Fries, H., Foullois, N., Müller, J., 2015. Bark beetles increase biodiversity while maintaining drinking water quality. Conserv. Lett.

Beukema, J.J., 1990-2015. Expected effects of changes in winter temperatures on benthic animals living in soft sediments in coastal North Sea areas. In: Beukema, J.J., Wolff, W.J., Brouns, J.W.N. (Eds.), Expected Effects of Climatic Change on Marine Coastal Ecosystems. Kluwer Academic Press, Dordrecht, pp. 83-92.

Beaulieu, S.E., 2001. Colonization of habitat islands in the deep sea: recruitment to glass sponge stalks. Deep-Sea Res. I 48, 1121-1137.

Bergmann, M., Dannheim, J., Bauerfeind, E., Klages, M., 2009. Trophic relationships along a bathymetric gradient at the deep-sea observatory HAUSGARTEN. DeepSea Res. I 56, 408-424.

Bergmann, M., Soltwedel, T., Klages, M., 2011. The interannual variability of megafaunal assemblages in the Arctic deep sea: preliminary results from the HAUSGARTEN observatory $\left(79^{\circ} \mathrm{N}\right)$. Deep-Sea Res. I 58, 711-723.

Berkes, F., Folke, C., 1998. Linking Social and Ecological Systems: Management Practices and Social Mechanisms for Building Resilience, vol. 1., pp. 13-20.

Beszczynska-Möller, A., Fahrbach, E., Schauer, U., Hansen, E., 2012. Variability in Atlantic water temperature and transport at the entrance to the Arctic Ocean, 1997-2010. ICES J. Mar. Sci., http://dx.doi.org/10.1093/icesjms/fss056.

Blümel, C., Domin, A., Krause, J.C., Schubert, M., Schiewer, U., Schubert, H., 2002. Der historische Makrophytenbewuchs der inneren Gewässer der deutschen Ostseeküste. RMB 10, 5-111.

Blume, H.-P., Fränzle, O., Hörmann, G., Irmler, U., Kluge, W., Schleuß, U., 2008. Ecological setting of the study area. In: Fränzle, O., Kappen, L., Blume, H.-P., Dierssen, K. (Eds.), Ecosystem Organization of a Complex Landscape Long-Term Research in the Bornhöved Lake District, Germany. Ecological Studies, vol. 202. Springer, Berlin, pp. 29-60.

Boetius, A., Lochte, K., 1994. Regulation of microbial enzymatic degradation of OM in deep-sea sediments. Mar. Ecol. Prog. Ser. 104, 299-307.

Borcherding, J., Staas, S., Krüger, S., Ondračková, M., Šlapanský, L., Jurajda, P., 2011. Non-native Gobiid species in the lower River Rhine (Germany): recent range extensions and densities. J. Appl. Ichthyol. 27, 153-155.

Borja, A., Ranasinghe, A., Weisberg, S.B., 2009. Assessing ecological integrity in marine waters, using multiple indices and ecosystem components: challenges for the future. Mar. Pollut. Bull. 59 (1), 1-4.

Bradley, L.R., Giesecke, T., Halsall, K., Bradshaw, R.H.W., 2013. Exploring the requirement for anthropogenic disturbance to assist the stand-scale expansion of Fagus sylvatica L. outside southern Scandinavia. Holocene 23, 579-586.

Brand, F., 2005. Ecological resilience and its relevance within a theory of sustainable development. UFZ-Reports 03/2005, Leipzig, 223 pp.

Burkhard, B., Fath, B.D., Müller, F., 2011. Adapting the adaptive cycle: hypotheses on the development of ecosystem properties and services. Ecol. Model. 222 2878-2890

Cabell, J.F., Oelofse, M., 2012. An indicator framework for assessing agroecosystem resilience. Ecol. Soc. 17 (1)

CABI, 2015. Invasive Species Compendium. CAB International, Wallingford, UK www.cabi.org/isc.

Carpenter, S.R., 2003. Regime Shifts in Lake Ecosystems: Pattern and Variation. International Ecology Institute, Oldendorf, Luhe, pp. 27-54.

Carpenter, S., Walker, B., Anderies, J.M., Abel, N., 2001. From metaphor to measurement: resilience of what to what? Ecosystems 4, 765-781, 2001

CGIAR Research Program on Water, Land and Ecosystems (WLE), 2014. Ecosystem services and resilience framework. International Water Management Institute (IWMI). CGIAR Research Program on Water, Land and Ecosystems (WLE) Colombo, Sri Lanka, http://dx.doi.org/10.5337/2014.229, 46 pp.

Chapin III, F.S., Peterson, G., Berkes, F., Callaghan, T.V., Angelstam, P., Apps, M., Beier C., Bergeron, Y., Crépin, A.-S., Danell, K., Elmqvist, T., Folke, C., Forbes, B., Fresco,
N., Juday, G., Niemelä, J., Shvidenko, A., Whiteman, G., 2004. Resilience and vulnerability of northern regions to social and environmental change. AMBIO 33 (6), 344-349.

Chapin III, F.S., McGuire, A.D., Ruess, R.W., Hollingsworth, T.N., Mack, M.C., Johnstone, J.F., Kasischke, E.S., Euskirchen, E.S., Jones, J.B., Jorgenson, M.T., Kielland K., Kofinas, G.P., Turetsky, M.R., Yarie, J., Lloyd, A.H., Taylor, D.L., 2010. Resilience of Alaska's boreal forest to climatic change. This article is one of a selection of papers from The dynamics of change in Alaska's Boreal forests: resilience and vulnerability in response to climate warming. Can. J. For. Res. 40 (7), 1360-1370

Conroy, J.D., Boegman, L., Zhang, H., Edwards, W.J., Culver, D.A., 2011. “Dead Zone” dynamics in Lake Erie: the importance of weather and sampling intensity for calculated hypolimnetic oxygen depletion rates. Aquat. Sci. 73, 289-304.

Cronan, C.S., Grigal, D.F., 1995. Use of calcium/aluminum ratios as indicators of stress in forest ecosystems. J. Environ. Qual. 24, 209-226.

Cumming, G.S., 2011a. Spatial Resilience in Social-Ecological Systems. Springer, Berlin, Heidelberg/New York, 254 pp.

De Angelis, D.L., 1980. Energy flow, nutrient cycling and ecosystems resilience. Ecology 61 (4), 764-771.

Deutsch, L., Folke, C., Skanberg, K., 2003. The critical natural capital of ecosystem performance as insurance for human well-being. Ecol. Econ. 44, 205-217.

Dippner, J.W., 2006. Future aspects in marine ecosystem modelling. Special WKFDPBI issue. J. Mar. Syst. 61, 246-267.

Dippner, J.W., Kröncke, I., 2003. Forecast of climate induced change in marine ecosystems. Clim. Res. 25, 179-182.

Dippner, J.W., Kröncke, I., 2015. Ecological forecasting in the presence of abrupt regime shifts. J. Mar. Syst., http://dx.doi.org/10.1016/j.jmarsys.2015.05.009.

Dippner, J.W., Junker, K., Kröncke, I., 2010. Biological regime shifts and changes in predictability. Geophys. Res. Lett. 37, L24701, 5 pp.

Dippner, J.W., Möller, C., Kröncke, I., 2014. Persistency of the North Atlantic Oscillation and its biological implication. Front. Ecol. Evol. 2 (57), 1-8.

Domin, A., Schubert, H., Krause, J.C., Schíewer, U., 2004. Modelling of pristine depth limits for macrophyte growth in the southern Baltic Sea. Hydrobiologia 514, 29-39.

Entling, W., Schmidt, M.H., Bacher, S., Brandl, R., Nentwig, W., 2007. Niche properties of Central European spiders: shading, moisture and the evolution of the habitat niche. Glob. Ecol. Biogeogr. 16, 440-448.

European Commission, 2000. Directive 2000/60/EC of the European Parliament and of the Council establishing a framework for the Community action in the field of water policy (EU Water Framework Directive). Off. J., L327.

European Commission, 2012. The EU approach to resilience: learning from food security crises; Document COM(2012) 586 final; Brussels.

Evans, J.P., 2011. Resilience, ecology and adaptation in the experimental city. Trans. Inst. Br. Geogr. 36 (2), 223-237.

Feder, H.M., Pearson, T.H., 1988. The benthic ecology of Loch Linnhe and Loch Eil, a sea-loch system on the West-Coast of Scotland. V. Biology of the dominant soft-bottom epifauna and their interaction with the infauna. J. Exp. Mar. Biol. Ecol. 116, 99-134.

Findlay, R.H., King, G.M., Watling, L., 1989. Efficiency of phospholipid analysis in determining microbial biomass in sediments. Appl. Environ. Microbiol. 55 2888-2893.

Fischer, A., Fischer, H., 2012. Individual-based analysis of tree establishment and forest stand development within 25 years after wind throw. Eur. J. For. Res. 131 493-501.

Fischer, C., Schröder, B., 2014. Predicting spatial and temporal habitat use of rodents in a highly intensive agricultural area. Agric. Ecosyst. Environ. 189, 145-153, http://dx.doi.org/10.1016/j.agee.2014.03.039.

Folke, C., 2006. The economic perspective: conservation against development versus conservation for development. Conserv. Biol. 20, 686-688.

Folke, C., Colding, J., Berkes, F., 2003. Synthesis: building resilience and adaptive capacity in socio-ecological sysems. In: Berkes, F., Colding. J., Folke, C. (Eds.) Navigating Social-Ecological Systems. Building Resilience for Complexity and Change. Cambridge University Press, Cambridge, pp. 352-387.

Fränzle, O., Kappen, L., Blume, H.-P., Dierssen, K. (Eds.), 2008. Ecosystem Organization of a Complex Landscape - Long-Term Research in the Bornhöved Lake District, Germany. Ecological Studies, vol. 202. Springer, Berlin, Heidelberg.

Fränzle, O., Schimming, C.-G., 2008. Element fluxes in atmosphere, vegetation and soil. In: Fränzle, O., Kappen, L., Blume, H.-P., Dierssen, K. (Eds.), Ecosystem Organization of a Complex Landscape Long-term Research in the Bornhöved Lake District, Germany. Ecological Studies, vol. 202. Springer, Berlin, pp. 169-206.

Froese, R., Pauly, D., 2014. FishBase. World Wide Web Electronic Publication www. fishbase.org.

Gallucci, F., Sauter, E., Sachs, O., Klages, M., Soltwedel, T., 2008a. Caging experiment in the deep sea: efficiency and artefacts from a case study at the Arctic long-term observatory HAUSGARTEN. J. Exp. Mar. Biol. Ecol. 354, 39-55.

Gallucci, F., Fonseca, G., Soltwedel, T., 2008b. Effects of megafauna exclusion on nematode assemblages at a deep-sea site. Deep-Sea Res. I 55, 332-349.

Garmestani, A.S., Allen, C.R., Benson, M.H., 2013. Can law foster social-ecological resilience? Ecol. Soc. 18 (2), 37, http://dx.doi.org/10.5751/ES-05927-180237.

Gigon, A., Grimm, V., 1997. Stabilitätskonzepte in der Ökologie: Typologie und Checkliste für die Anwendung. In: Fränzle, O., Müller, F., Schröder, W. (Eds.), Handbuch der Umweltwissenschaften. Ecomed, Landsberg, pp. 1-19.

Gnauck, A., Jørgensen, S.E., Luther, B., 2010. The role of ecosystem modelling for longterm ecological research. In: Müller, F., Baessler, C., Schubert, H., Klotz, S. (Eds.) Long-Term Ecological Research. Between Theory and Application. Springer, Dordrecht, pp. 95-105. 
Grimm, V., Wissel, C., 1997. Babel, or the ecological stability discussions: an inventory and analysis of terminology and a guide for avoiding confusion. Oecologia 109, 323-334.

Grimm, V., Calabrese, J.M., 2011. What is resilience? A short introduction. In: Deffuant, G., Gilbert, N. (Eds.), Viability and Resilience of Complex Systems. Springer, Berlin, pp. 3-13.

Grimm, V., Schmidt, E., Wissel, C., 1992. On the application of stability concepts in ecology. Ecol. Model. 63, 143-161.

Grunewald, K., Bastian, O. (Eds.), 2012. Ökosystemdienstleistungen. Konzept, Methoden und Fallbeispiele, Berlin.

Gundersson, L.H., Holling, C.S. (Eds.), 2002. Panarchy. Island Press, Washington, Covelo/London.

Gunderson, L.H., Pritchard, L. (Eds.), 2012. Resilience and the Behavior of Large-Scale Systems. Island Press, Washington, DC, 240 pp.

Gunderson, L.H., Allen, C.R., Holling, C.S. (Eds.), 2012. Foundations of Ecological Resilience. Island Press.

Haase, P., Hering, D., Jähnig, S.C., Lorenz, A.W., Sundermann, A., 2013. The impact of hydromorphological restoration on river ecological status: a comparison of fish, benthic invertebrates, and macrophytes. Hydrobiologia 704, 475-488.

Haines-Young, R., Potschin, M., Kienast, F., 2012. Indicators of ecosystem service potential at European scales: mapping marginal changes and trade-offs. Ecol. Indic. 21, 39-53.

Harrison, I., Laverty, M., Sterling, E., 2004. Introduction to the Importance of Biodiversity. Connexions. http://cnx.rice.edu/content/m12163/latest/.

Hauhs, M., 1989. Lange Bramke. In: Adriano, D.C., Havas, M. (Eds.), Acidic Precipitation - Advances in Environmental Science, vol. 1, pp. 275-305

Hauhs, M., Lange, H., 2010. The land use history of the Lange Bramke catchments, Harz mountains. In: Status and Perspectives of Hydrology in Small Basins (Proceedings of the Workshop held at Goslar-Hahnenklee, Germany, 30 March-2 April 2009), IAHS Publ. 336, pp. 19-23.

Herlyn, M., 1996. Zur Bestandssituation der Miesmuschelbänke des niedersächsischen Wattenmeeres. - Mitteilungen aus der NNA 1/1996. Schneverding, pp. $56-61$

Herlyn, M., (Dissertation) 2009. Der Miesmuschelbestand der niedersächsischen Watten - quantitative Erfassung und räumlich-zeitliche Variabilität. Univ. Oldenburg, 43 pp. und Anhang I bis IV.

Holling, C.S., 1973. Resilience and stability of ecological systems. Annu. Rev. Ecol. Syst. 4, 1-23.

Holling, C.S., Gunderson, L.H., 2002. Resilience and adaptive cycles. In: Gundersson, L.H., Holling, C.S. (Eds.), Panarchy. Island Press, Washington, Covelo/London, pp. $25-62$.

Hurrell, J.W., 1995. Decadal trends in the North Atlantic Oscillation: regional temperatures and precipitation. Science 269, 676-679.

Husson, F., Josse, J., Le, S., Mazet, J., 2015. Package 'FactoMineR' - Multivariate Exploratory Data Analysis and Data Mining with R. http://cran.r-project.org/ web/packages/FactoMineR/FactoMineR.pdf:CRAN.

ICP-Forests, 2015. http://icp-forests.net (assessed 21.04.15).

Ilisson, T., Chen, H., 2009. The direct regeneration hypothesis in northern forests. J. Veg. Sci. 20, 735-744

Irmler, U., Dilly, O., Schrautzer, J., Dierssen, K., 2008. Site-related biocoenotic dynamics. In: Fränzle, O., Kappen, L., Blume, H.-P., Dierssen, K. (Eds.), Ecosystem Organization of a Complex Landscape Long-term Research in the Bornhöved Lake District, Germany. Ecological Studies, vol. 202. Springer, Berlin, pp. 119-145.

Jackson, J.K., Fuereder, L., 2006. Long-term studies of freshwater macroinvertebrates: a review of the frequency, duration and ecological significance. Freshw. Biol. 51 (3), 591-603.

Janssen, M.A., Schoon, M.L., Ke, W., Borner, K., 2006. Scholarly networks on resilience, vulnerability and adaptation within the human dimensions of global environmental change. Glob. Environ. Chang. 16, 240-252.

Jennings, E., Jones, S., Arvola, L., Staehr, P.A., Gaiser, E., Jones, I.D., Weathers, K.C., Weyhenmey, G.A., Chiu, C.Y., de Eyto, E., 2012. Effects of weather-related episodic events in lakes: an analysis based on high-frequency data. Freshw. Biol. 57, 589-601.

Jentsch, A., Kreyling, J., Beierkuhnlein, C., 2007. A new generation of climate change experiments: events, not trends. Front. Ecol. Envir. 5, 315-324.

Jeppesen, E., Søndergaard, M., Kanstrup, E., Petersen, B., Eriksen, R.B., Hammershøj, M., Mortensen, E., Jensen, J.P., Have, A., 1994. Does the impact of nutrients on the biological structure and function of brackish and freshwater lakes differ? Hydrobiologia 275/276, 15-30.

Jeppesen, E., Søndergaard, M., Jensen, J.P., Havens, K.E., Anneville, O., Carvalho, L, Coveney, M.F., Deneke, R., Dokulil, M.T., Foy, B., Gerdeaux, D., Hampton, S.E., Hilt, S., Kangur, K., Kohler, J., Lammens, E.H.H.R., Lauridsen, T.L., Manca, M., Miracle, M.R., Moss, B., Nõges, P., Persson, G., Phillips, G., Portielje, R., Romo, S., Schelske, C.L., Straile, D., Tatrai, I., Willen, E., Winder, M., 2005. Lake responses to reduced nutrient loading - an analysis of contemporary long-term data from 35 case studies. Freshw. Biol. 50, 1747-1771, http://dx.doi.org/10.1111/j.13652427.2005.01415.x.

Jochimsen, M.C., Kümmerlin, R., Straile, D., 2013. Compensatory dynamics and the stability of phytoplankton biomass during four decades of eutrophication and oligotrophication. Ecol. Lett. 16, 81-99, http://dx.doi.org/10.1111/ele.12018.

Jonášová, M., Pracha, K., 2004. Central-European mountain spruce (Picea abies (L.) Karst.) forests: regeneration of tree species after a bark beetle outbreak. Ecol. Eng. 23, 15-27.

Jorgensen, S.E., 1992. Integration of Ecosystem Theories: A Pattern. Kluwer, Dordrecht.
Jørgensen, S.E 2012. Introduction to Systems Ecology. CRC Press, Boca Raton.

Joergensen, S.E., Fath, B., Bastianoni, S., Marquez, J., Müller, F., Nielsen, S.N., Patten, B., Tiezzi, E., Ulanowicz, R. (Eds.), 2007. A New Ecology - The Systems Perspective. Elsevier Publishers, Amsterdam, p. 288

Joergensen, S.E., Xu, L., Costanza, R. (Eds.), 2010. Handbook of Ecological Indicators for Assessment of Ecosystem Health. CRC Press.

Junker, K., Sovilj, D., Kröncke, I., Dippner, J.W., 2012. Climate induced changes in benthic macrofauna - a non-linear model approach. J. Mar. Syst. 96-97, 90-94.

Kaiser, K., Schoknecht, T., Janke, W., Kloss, K., Prehn, B., 2002. Geomorphologische, palynologische und archäologische Beiträge zur holozänen Landschaftsgeschichte im Müritzgebiet (Mecklenburg-Vorpommern). Eiszeitalter und Gegenwart 51, 15-32.

Kandziora, M., Burkhard, B., Müller, F., 2013. Interactions of ecosystem properties, ecosystem integrity and ecosystem service indicators-a theoretical matrix exercise. Ecol. Indic. 28, 54-78.

Kaufmann, R.S., Smith, K.L., 1997. Activity patterns of mobile epibenthic megafauna at an abyssal site in the eastern North Pacific: results from a 17-month timelapse photographic study. Deep-Sea Res. I 44, 559-579.

Keatley, B.E., Bennett, E.M., MacDonald, G.K., Taranu, Z.E., Gregory-Eaves, I., 2011. Land-use legacies are important determinants of lake eutrophication in the anthropocene. PLoS ONE, 6, http://dx.doi.org/10.1371/journal.pone.0015913.

Kerimoglu, O., Straile, D., Peeters, F., 2013. Seasonal, inter-annual and long term variation in top-down versus bottom-up regulation of primary production. Oikos 122, 223-234, http://dx.doi.org/10.1111/j.1600-0706.2012.20603.x.

Klinck, U., Rademacher, P., Scheler, B., Wagner, M., Fleck, S., Ahrends, B., Meesenburg, H., 2012. Ökosystembilanzen auf forstwirtschaftlich genutzten Flächen. In: Höper, H., Meesenburg, H. (Eds.), 20 Jahre Bodendauerbeobachtung in Niedersachsen, 23. Geoberichte, pp. 163-174.

Klug, J.L., Richardson, D.C., Ewing, H.A., Hargreaves, B.R., Samal, N.R., Vachon, D., Pierson, D.C., Lindsey, A.M., O’Donnell, D.M., Effler, S.W., Weathers, K.C., 2012. Ecosystem effects of a tropical cyclone on a network of lakes in north-eastern North America. Environ. Sci. Technol. 46, 11693-11701.

Koschel, R., Benndorf, J., Proft, G., Recknagel, F., 1983. Calcite precipitation as a natural control mechanism of eutrophication. Arch. Hydrobiol. 98, 380-408.

Koschel, R., Adams, D., 2003. Preface: an approach to understanding a temperate oligotrophic lowland lake (Lake Stechlin, Germany). Arch. Hydrobiol. Spec. Issues Advanc. Limnol., 1-9.

Kottelat, M., Freyhof, J., 2007. Handbook of European Freshwater Fishes. Publications Kottelat, Cornol, Switzerland.

Krause-Jensen, D., Sagert, S., Schubert, H., Boström, C., 2008. Empirical relationship linking abundance of marine vegetation to eutrophication. Ecol. Indic. 8, 515-529.

Kröncke, I., Dippner, J.W., Heyen, H., Zeiss, B., 1998. Long-term changes in the macrofauna communities off Norderney (East Frisia, Germany) in relation to climate variability. Mar. Ecol. Prog. Ser. 167, 25-36.

Kröncke, I., Reiss, H., 2010. Long-term variability of benthic indices off the island of Norderney in the southern North Sea. Mar. Pollut. Bull. 60, 58-68.

Kröncke, I., Reiss, H., Dippner, J.W., 2013. Effects of cold winters and regime shifts on macrofauna communities in the southern North Sea. Estuar. Coast. Shelf Sci. 119, 79-90.

Küster, M., (Dissertation) 2014. Holozäne Landschaftsentwicklung der Mecklenburgischen Seenplatte: Relief- und Bodengenese, hydrologische Entwicklung sowie Siedlungs- und Landnutzungsgeschichte in Nordostdeutschland. Universität Greifswald.

Küster, M., Fülling, A., Kaiser, K., Ulrich, J., 2014. Aeolian sands and buried soils in the Mecklenburg Lake District, NE Germany: holocene land-use history and pedogeomorphic responce. Geomorhology 211, 64-76.

Küster, M., Janke, W., Meyer, H., Lorenz, S., Lampe, R., Hübener, T., Klamt, A.M., 2012. Zur jungquartären Landschaftsentwicklung der Mecklenburgischen Kleinseenplatte: Geomorphologische, bodenkundliche und limnogeologische Untersuchungen am Krummen See bei Blankenförde (Mecklenburg). In: Nationalparkamt Müritz (Hrsg): Forschung und Monitoring. Band 3; Greifswald (Geozon).

Lalande, C., Bauerfeind, E., Nöthig, E.-M., Beszczynska-Möller, A., 2013. Impact of a warm anomaly on export fluxes of biogenic matter in the eastern Fram Strait. Prog. Oceanogr. 109, 70-77.

Lischeid, G., Natkhin, M., Steidl, J., Dietrich, O., Dannowski, R., Merz, C., 2010. Assessing coupling between lakes and layered aquifers in a complex Pleistocene landscape based on water level dynamics. Adv. Water Resour. 33, 1331-1339, http://dx.doi.org/10.1016/j.advwatres.2010.08.002.

Loewe, P., 2009. Atmosphärenphysik. In: Loewe, P. (Ed.), System Nordsee. Berichte des Bundesamtes für Seeschiffahrt und Hydrographie, vol. 44, pp. 35-78.

Ludwig, D., Walker, B., Holling, C.S., 1997. Sustainability, stability, and resilience. Conserv. Ecol., Available from http://www.consecol.org/vol1/iss1/art7/.

Martin, S., 2004. The cost of restoration as a way of defining resilience: a viability approach applied to a model of lake eutrophication. Ecol. Soc. 9 (2.)

Martin, S., Deffuant, G., Calabrese, J.M., 2011. defining resilience mathematically: from attractors to viability. In: Deffuant, G., Gilbert, N. (Eds.), Viability and Resilience of Complex Systems. Springer, Berlin, pp. 15-36.

Mazzocchi, M.G., Dubroca, L., García-Comas, C., Di Capua, I., d'Alcalà, M.R., 2012. Stability and resilience in coastal copepod assemblages: the case of the Mediterranean long-term ecological research at Station MC (LTER-MC). Prog. Oceanogr. 97, 135-151

McQuatters-Gollop, A., Raitsos, D.E., Edwards, M., Pradhan, Y., Mee, L.D., Lavender, S.J., Attrill, M.J., 2007. A long-term chlorophyll data set reveals regime shift 
in North Sea phytoplankton biomass unconnected to nutrient trends. Limnol. Oceanogr. 52, 635-648.

Meesenburg, H., Meiwes, K.J., Rademacher, P., 1995. Long term trends in atmospheric deposition and seepage output in northwest German forest ecosystems. Water Air Soil Pollut. 85, 611-616.

Meesenburg, H., Sutmöller, J., Hentschel, S., 2010. Retrospective and prospective evaluation of water budgets at Lange Bramke, Harz Mountains, Germany: effects of plant cover and climate change. In: Status and Perspectives of Hydrology in Small Basins (Proceedings of the Workshop held at Goslar-Hahnenklee, Germany, 30 March-2 April 2009), IAHS Publ. 336, pp. 239-244.

Meyer, K., Bergmann, M., Soltwedel, T., 2013. Interannual variation in the epibenthic megafauna at the shallowest station of the HAUSGARTEN observatory $\left(79^{\circ} \mathrm{N}\right.$ $\left.6^{\circ} \mathrm{E}\right)$. Biogeosciences 10, 3479-3492.

Michaelis, H., Obert, B., Schultenkötter, I., Böcker, L., 1995. Die Miesmuschelbeständ der Niedersächsischen Watten 1989-1991. Berichte Forschungsstelle Küste, 40, Norderney, $20 \mathrm{pp}$

Millat, G., 2006. Die Entwicklung des eulitoralen Miesmuschelbestandes im niedersächsischen Wattenmeer. In: Forschungszentrum Terramare, Berichte Nr. 15. pp. 14-17.

Millat, G., 2014. Invasion der Pazifischen Auster (Crassostrea gigas) im Nationalpark Niedersächsisches Wattenmeer und ihre Folgen für die Miesmuschelbänke. In Scherfose, V. (Hrsg.). Nationalparkmanagement in Deutschland. - Naturschutz und Biologische Vielfalt, BfN, H. 136, 59-76.

Millat, G., Herlyn, M., 1999. Erfassung und Dokumentation des Miesmuschelbestandes der niedersächsischen Watten sowie Untersuchung und Bewertung alternativer Methoden der Besatzmuschelgewinnung. - Forschungsprojekt der niedersächsischen Wattenmeerstiftung, Final Report Dec. 1999 (unpubl.).

Millat, G., Borchardt, T., Herlyn, M., Adolph, W., 2009. Die Entwicklung des eulitoralen Miesmuschelbestandes (Mytilus edulis) in den deutschen Wattgebieten, Meeresumwelt Aktuell Nord- und Ostsee, 2009/5 BSH, Hamburg und Rostock.

Millat, G., Borchadt, T., Bartsch, I., Adolph, W., Herlyn, M., Reichert, K., Kuhlenkamp, R., Schubert, P., 2012. Die Entwicklung des eulitoralen Miesmuschelbestandes (Mytilus edulis) in den deutschen Wattgebieten (aktualisierte Fassung des Berichts 2009/5). - Meeresumwelt Aktuell Nord- und Ostsee, 2012/2, BSH, Hamburg und Rostock.

Mirschel, W., Wieland, R., Voss, M., Ajibefun, I., Deumlich, D., 2006. Spatial analysis and modeling tool (SAMT) 2. Applications. Ecol. Inform. 1 (1),77-85.

Mirtl, M., Orenstein, D.E., Wildenberg, M., Peterseil, J., Frenzel, M., 2013. Development of LTSER platforms in LTER-Europe: challenges and experiences in implementing place-based long-term socio-ecological research in selected regions. In: Long Term Socio-Ecological Research. Springer, Netherlands, pp. 409-442.

Müller, F., 1992. Hierarchical approaches to ecosystem theory. Ecological Modelling, vol. 63., pp. 215-242

Müller, F., 2005. Indicating ecosystem and landscape organization. Ecol. Indic. 5/4, 280-294.

Müller, F., Leupelt, M., 1998. Eco-Targets, Goal Functions and Orientors. Springer, Berlin.

Müller, F., Schrautzer, J., Reiche, E.-W., Rinker, A., 2006. Ecosystem based indicators in retrogressive successions of an agricultural landscape. Ecol. Indic. 6, 63-82.

Müller, F., Burkhard, B., Kroll, F., 2010a. Resilience, integrity and ecosystem dynamics: bridging ecosystem theory and management. In: Otto, J.-C., Dikau, R. (Eds.), Landform - Structure, Evolution, Process Control. Lecture Notes in Earth Sciences Series, vol. 115. Springer, pp. 221-242.

Müller, H.M., (Dissertation) 1962. Pollenanalytische Untersuchungen im Bereich des Meßtischblattes Thurow/Südostmecklenburg. Universität Halle/Saale.

Müller, J., Noss, R., Bussler, H., Brandl, R., 2010b. Learning from a "benign neglect strategy" in a national park: response of saproxylic beetles to dead wood accumulation. Biol. Conserv. 143, 2559-2569.

Nehring, S., 2005. www.aquatic-aliens.de.

Newton, A.C., 2011. Social-ecological resilience and biodiversity conservation in a 900-year-old protected area. Ecol. Soc. 16 (4), 13, http://dx.doi.org/10.5751/ES04308-160413.

Nielsen, R., Kristiansen, A., Mathiesen, L., Mathiesen, H., 1995. Distributional index of the benthic macroalgae of the Baltic Sea area. Acta Bot. Fennica 155, 1-50.

Obert, B., Michaelis, H., 1989. Geschichte und Ökologie der Miesmuschelbänke im Einzugsbereich des Norderneyer Seegats. - Dienstbericht des NLWA Forschungsstelle Küste (unpubl.).

Obert, B., Michaelis, H., 1991. History and ecology of the mussel beds (Mytilus edulis L.) in the catchment area of a Wadden Sea tidal inlet. In: Elliot, M., Ducrotoy, T.P. (Eds.), Estuaries and Coasts: Spatial and Temporal Intercomparisons. Olsen \& Olsen, pp. 185-194.

O’Neill, R.V., de Angelis, D.L., Waide, J.B., Allen, T.H.F., 1986. A Hierarchical Concep of Ecosystems. Monographs in Population Ecology, vol. 23. Princeton University Press.

Ontrup, J., Ehnert, N., Bergmann, M., Nattkemper, T.W., 2009. BIIGLE-Web 2.0 enabled labelling and exploring of images from the Arctic deep-sea observatory HAUSGARTEN. In: OCEANS 2009- EUROPE. IEEE, pp. 1-7.

Ott, K., 2001. Eine Theorie starker Nachhaltigkeit. Natur und Kultur 2/1, 55-75.

Pahl-Wostl, C., 1997. The Dynamic Nature of Ecosystems - Chaos and Order Entwined. Wiley, Chichester.

Pahl-Wostl, C., 2000. Ecosystems as dynamic networks. In: Iørgensen, S.E., Müller F. (Eds.), Handbook of Ecosystem Theories and Management. Lewis Publ., Boca Raton, pp. 317-343.
Parr, T.W., Sier, A.R., Battarbee, R.W., Mackay, A., Burgess, J., 2003. Detecting environmental change: science and society-perspectives on long-term research and monitoring in the 21st century. Sci. Total Environ. 310 (1), 1-8.

Peterson, G.D., 2002. Estimating resilience across landscapes. Conserv. Ecol. 6 (1), 17.

Piepenburg, D., 2005. Recent research on Arctic benthos: common notions need to be revised. Pol. Biol. 28, 733-755.

Piepenburg, D., Blackburn, T.H., Vondorrien, C.F., Gutt, J., Hall, P.O.J., Hulth, S., Kendall, M.A., Opalinski, K.W., Rachor, E.,Schmid, M.K. 1995. Partitioning of benthic community respiration in the Arctic (Northwestern Barents Sea). Mar. Ecol. Prog. Ser. $118,199-213$

Pimm, S.L., 1984. The complexity and stability of ecosystems. Nature 307, 321-326. Pimm, S.L., Lawton, J., Cohen, J., 1991. Food web patterns and their consequences. Nature 350, 669-674.

Pinto, R., Patrício, J., Baeta, A., Fath, B.D., Neto, J.M., Marques, J.C., 2009. Review and evaluation of estuarine biotic indices to assess benthic condition. Ecol. Indic. 9 (1), $1-25$.

Plieninger, T., Bieling, C. (Eds.), 2012. Resilience and the Cultural Landscape. Cambridge University Press, Cambridge, 348 pp.

Prechtel, A., Alewell, C., Armbruster, M., Bittersohl, J., Cullen, J., Evans, C., Helliwell, R., Kopacek, J., Marchetto, A., Matzner, E., Meesenburg, H., Moldan, F., Moritz, K., Vesely, J., Wright, R.F., 2001. Response of sulfur dynamics in European catchments to decreasing sulfate deposition. Hydrol. Earth Syst. Sci. 5, 311-325.

Prowse, T.D., Wrona, F.J., Reist, J.D., Gibson, J.J., Hobbie, J.E., Lévesque, L.M., Vincent, W.F., 2006. Climate change effects on hydroecology of Arctic freshwater ecosystems. AMBIO 35 (7), 347-358.

Pugnetti, A., Acri, F., Bernardi Aubry, F., Camatti, E., Cecere, E., Facca, C., Franzoi, P., Keppel, E., Lugliè, A., Mistri, M., Munari, C., Padedda, B.M., Petrocelli, A., Pranovi, F., Pulina, S., Satta, C.T., Sechi, N., Sfriso, A., Sigovini, M., Tagliapietra, D. Torricelli, P., 2013. The Italian Long-Term Ecosystem Research (LTER-Italy) network: results, opportunities, and challenges for coastal transitional ecosystems. Transit. Waters Bull. 7 (1), 43-63.

Ralska-Jasiewiczowa, M., Nalepka, D., Goslar, T., 2003. Some problems of forest transformation at the transition to the oligocratic/Homo sapiens phase of the Holocene interglacial in northern lowlands of central Europe. Veg. Hist. Archaeobot. 12, 233-247.

Redman, C., Grove, J.M., Kuby, L., 2000. Toward a unified understanding of human ecosystems: Integrating social sciences into long-term ecological research. White Paper of the Social Science Committee of the LTER Network. http://www lternet. edu/documents/Publications/sosciwhtppr/index. html.

Redman, C.L., Kinzig, A.P., 2003. Resilience of past landscapes: resilience theory, society, and the longue durée. Conserv. Ecol. 7 (1), 14

Redman, C.L., Grove, J.M., Kuby, L.H., 2004. Integrating social science into the longterm ecological research (LTER) network: social dimensions of ecological change and ecological dimensions of social change. Ecosystems 7 (2), 161-171.

Reiche, E.W., 1996. WASMOD. Ein Modellsystem zur gebietsbezogenen Simulation von Wasser- und Stoffflüssen. Ecosys 4, 143-163.

Reise, K., 1994. Changing life under the tides of the Wadden Sea during the 20th century. Ophelia Suppl. 6, 117-125.

Remane, A., 1934. Die Brackwasserfauna. Verhandlungen der Deutschen Zoologischen Gesellschaft, Greifswald, pp. 34-74.

Remane, A., 1958. Ökologie des Brackwassers. In: Remane, A., Schlieper, C. (Eds.) Die Biologie des Brackwassers, Binnengewässer, vol. 22, pp. 1-216.

Resilience Alliance, 2010. Assessing resilience in social-ecological systems: workbook for practitioners, Version 2.0. http://www.resalliance.org/3871.php.

Reuss, J.O., Johnson, D.W., 1985. Effect of soil processes on the acidification of water by acid deposition. J. Environ. Qual. 14, 26-31.

Richter, D., 1995. Ergebnisse methodischer Untersuchungen zur Korrektur des systematischen Messfehlers des Hellmann-Niederschlagsmessers. Berichte des Deutschen Wetterdienstes, 194

Ruhl, H.A., 2007. Abundance and size distribution dynamics of abyssal epibenthic megafauna in the Northeast Pacific. Ecology 88, 1250-1262

Sanz, A.S.R., Fernandez, C., Mouillot, F., Ferrat, L., Istria, D., Pasqualini, V., 2013. Long-term forest dynamics and land-use abandonment in the Mediterranean mountains, Corsica, France. Ecol. Soc. 18 (2), 38.

Sardá, R., Foreman, K., Werme, C.E., Valiela, I., 1998. The impact of epifaunal predation on the structure of macroinfaunal invertebrate communities of tidal saltmarsh creeks. Estuar. Coast. Shelf Sci. 46, 657-669.

Scamoni, A. (Ed.), 1963. Natur, Entwicklung und Wirtschaft einer jungpleistozänen Landschaft dargestellt am Gebiet des Meßtischblattes Thurow (Kreis Neustrelitz). Teil I: Geographische, standörtliche und vegetationskundliche Grundlagen, Ornithologie und Wildforschung. Wissenschaftliche Abhandlungen der Deutschen Akademie für Landwirtschaften zu Berlin: 56. Akademie-Verlag, Berlin.

Schaefer, M., Tischler, W., 1983. Dictionary of Biology - Ecology, 2nd rev. Fischer Jena.

Scheffer, M., 1998. Ecology of Shallow Lakes. Chapman and Hall, New York

Scheffer, M., Hosper, S.H., Meijer, M.L., Moss, B., Jeppesen, E., 1993. Alternative equilibria in shallow lakes. Trends Ecol. Evol. 8, 275-279.

Scheffer, M., Carpenter, S., Foley, J.A., Folke, C., Walker, B., 2001. Catastrophic shifts in ecosystems. Nature 413, 591-596.

Scheffer, M., Carpenter, S.R., 2003. Catastrophic regime shifts in ecosystems: linking theory to observation. Trends Ecol. Evol. 12, 648-656.

Scheffer, M., Carpenter, S.R., Lenton, T.M., Lenton, T.M., Bascompte, J., Brock, W. Dakos, V., van de Koppel, J., van de Leemput, I.A., Levin, S.A., van Nes, E.H., 
Pascual, M., John Vandermeer, J., 2012. Anticipating critical transitions. Science 338, 344-348.

Schiewer, U., 1994. Regulationsmechanismen und Wechselwirkungen zwischen Pelagial und Benthal. RMB 2,179-189.

Schimming, C.-G., Burckhard, B., Müller und, F., Ulrich, U., 2011. Trendanalyse der Biogeochemie eines Buchenwaldökosystems - Konzepte zur Identifizierung und Indikation von Ökosystemfunktionen. In: Gnauck, A. (Hrsg.). Modellierung von Ökosystemen - Workshop Kölpingsee 2011, ASMI Mitteilungen AM 138, Shaker Aachen.

Schimming, C.-G., Augustin, S., Karez, R., 2010. In: Müller, F.C., Baesler, H., Schubert, S., Klotz (Eds.), Long-Term Ecological Search - Between Theory and Application. Springer, Dordrecht.

Schindler, D.W., Vallentyne, J.R., 2008. The Algal Bowl: Overfertilization of the World's Freshwaters and Estuaries. University of Alberta Press.

Schmidt-Kloiber, A., Hering, D., 2015. www.freshwaterecology.info - an online tool that unifies, standardises and codifies more than 20,000 European freshwater organisms and their ecological preferences. Ecol. Ind. 53, 271-282.

Schrautzer, J., Rinker, A., Jensen, K., Müller, F., Schwartze, P., Dierssen, K., 2007. Succession and restoration of drained fens: perspectives from Northwestern Europe. In: Walker, L., Hobs, R.J., Walker, J. (Eds.), Linking Restoration and Ecological Succession. Springer Series on Environmental Management. Springer, pp. 90-120.

Schubert, H., Feuerpfeil, P., Marquardt, R., Telesh, I.V., Skarlato, S.O., 2011. Macroalgal diversity along the Baltic Sea salinity gradient challenges Remane's species minimum concept. Mar. Pollut. Bull. 62 (9), 1948-1956.

Schumann, R., Schoor, A., Schubert, H., 2009. Fine resolution of primary production and its limitation in phytoplankton communities of the Darss-Zingst Bodden Chain, a coastal lagoon of the southern Baltic Sea. Baltic Coast. Zone 13 (II), 97-125.

Selig, U., Steinhardt, T., Schubert, H., 2009. Interannual variability of submerged vegetation in a brackish coastal lagoon on the southern Baltic Sea. Ekologia 28 (4), 412-423.

Shade, A., Read, J.S., Youngblut, N.D., Fierer, N., Knight, R., Kratz, T.K., Lottig, N.R., Roden, E.E., Stanley, E.H., Stombaugh, J., Whitaker, R.J., Wu, C.H., McMahon, K.D., 2012. Lake microbial communities are resilient after a whole-ecosystem disturbance. ISME J. 6 (12), 2153-2167.

Shatwell, T., Kasprzak, P., Hupfer, M., 2012. The influence of climate change on oxygen and phosphorus in deep Lake Stechlin, German. Limnol Society Extended Abstracts Hardegsen, pp. 302-306.

Shuman, F.R., Lorenzen, C.J., 1975. Quantitative degradation of chlorophyll by a marine herbivore. Limnol. Oceanogr. 20, 580-586.

Soltwedel, T., Bauerfeind, E., Bergmann, M., Budaeva, N., Hoste, E., Jaeckisch, N., Juterzenka, K.v., Matthiessen, J., Mokievsky, V., Nöthig, E.-M., Quéric, N.-V., Sablotny, B., Sauter, E., Schewe, I., Urban-Malinga, B., Wegner, J., WlodarskaKowalczuk, M., Klages, M., 2005. HAUSGARTEN: multidisciplinary investigations at a deep-sea, long-term observatory in the Arctic Ocean. Oceanography 18 , 46-61.

Spangenberg, A., (Dissertation) 2008. 2000 Jahre Waldentwicklung auf nährstoffund basenreichen Standorten im mitteleuropäischen Jungpleistozän - Fallstudie Naturschutzgebiet Eldena (Vorpommern Deutschland). Universität Greifswald.

Spencer, M., Birchenough, S.N.R., Mieszkowska, N., Robinson, L.A., Simpson, S.D. Burrows, M.T., Capasso, E., Cleall-Harding, P., Crummy, J., Duck, C., Eloire, D., Frost, M., Hall, A.J., Hawkins, S.J., Johns, D.G., Sims, D.W., Smyth, T.J., Frid, C.L.J., 2011. Temporal change in UK marine communities: trends or regime shifts. Mar. Ecol. 32 (Suppl. 1), 1-15.

Standish, R.J., Hobbs, R.J., Mayfield, M.M., Bestelmeyer, B.T., Suding, K.N., Battaglia, L.L., Eviner, V., Hawkes, C.V., Temperton, V.M., Cramer, V.A., Harris, J.A., Funk, J.L., Thomas, P.A., 2014. Resilience in ecology: abstraction, distraction, or where the action is? Biol. Conserv. 177, 43-51.

Stockholm Resilience Center, 2015. What is Resilience, http://www. stockholmresilience.org/21/research/research-news/2-19-2015-what-isresilience.html.

Stoll, S., Frenzel, M., Burkhard, B., Adamescu, M., Augustaitis, A., Baeßler, C., Bonet, F.J., Cazacu, C., Cosor, G.L., Díaz-Delgado, R., Carranza, M.L., Grandin, U., Haase, P. Hämäläinen, H., Loke, R., Müller, J., Stanisci, A., Staszewski, T., Müller, F., 2015. Assessment of ecosystem integrity and service gradients across Europe using the LTER Europe network. Ecol. Model. 295, 75-87.

Straile, D., 2015. Zooplankton biomass dynamics in oligotrophic versus eutrophic conditions: a test of the PEG model. Freshw. Biol. 60, 174-183, http://dx.doi. org/10.1111/fwb.12484.

Straškraba, M., Gnauck, A., 1985. Freshwater Ecosystems - Modelling and Simulation. Elsevier, Amsterdam.

Sverdrup, H., Warfvinge, P., 1993. The effect of soil acidification on the growth of trees, grass and herbs as expressed by the $(\mathrm{Ca}+\mathrm{Mg}+\mathrm{K}) / \mathrm{Al}$ ratio. Rep. Ecol. Environ. Eng. 2, 1993.

Swanson, K.L., Tsonis, A.A., 2009. Has the climate recently shifted? Geophys. Res. Lett. 36, L06711.
Symstad, A.J., Chapin, F.S., Wall, D.H Gross, K.L. Huenneke, L.F., Mittelbach, G.G., Peters, P.C., Tilman, D., 2003. Long-term and large-scale perspectives on the relationship between biodiversity and ecosystem functioning. Bioscience 53 (1), 89-98.

Taranu, Z.E., Gregory-Eaves, I., Leavitt, P.R., Bunting, L., Buchaca, T., Catalan, J., Domaizon, I., Guilizzoni, P., Lami, A., McGowan, S., Moorhouse, H., Morabito, G., Pick, F.R., Stevenson, M.A., Thompson, P.L., Vinebrooke, R.D., 2015. Acceleration of cyanobacterial dominance in north temperate-subarctic lakes during the Anthropocene. Ecol. Lett. 18, 375-384, http://dx.doi.org/10.1111/ele.12420.

R Development Core Team, 2011. R: A Language and Environment for Statistical Computing. R Foundation for Statistical Computing, Vienna, Austria.

Turner, M., Collins, S.L., Lugo, A.L., Magnuson, J.J., Rupp, T.S., Swanson, F.J., 2003. Disturbance dynamics and ecological response: the contribution of long-term ecological research. Bioscience 53, 46-56.

Ulrich, B., 1985. Interactions of indirect effects of air pollutants. In: Troyanowski, C. (Ed.), Air Pollution and Plants. Wiley, Weinheim.

Ulrich, B., 1986. Natural and anthropogenic components of soil acidification. Z. Pflanzenernähr. Bodenk. 149, 702-717.

Ulrich, B., 1994. Nutrient and acid/base budget of central European forest ecosystems. In: Hüttermann, A., Godbold, D.L. (Eds.), Effects of Acid Rain on Forest Processes. Wiley, New York, pp. 1-50.

Vachon, D., del Giorgio, P.A., 2014. Whole-lake $\mathrm{CO}_{2}$ dynamics in response to storm events in two morphologically different lakes. Ecosystems 17, 1338-1353.

van Beusekom, J., Bot, P., Carstensen, J., Goebel, J., Lenhart, H., Patsch, J., Petenati, T., Raabe, T., Reise, K., Wetsteijn, B., 2009. Eutrophication. Thematic Report No. 6. In: Marencic, H., Vlas de, J. (Eds.), Quality Status Report 2009. Wadden Sea Ecosystem No. 25. Common Wadden Sea Secretariat, Trilateral Monitoring and Assessment Group, Wilhelmshaven, Germany, p. 21.

Vihervaara, P., D’Amato, D., Forsius, M., Angelstam, P., Baessler, C., Balvanera, P., .. . Zacharias, S., 2013. Using long-term ecosystem service and biodiversity data to study the impacts and adaptation options in response to climate change: insights from the global ILTER sites network. Curr. Opin. Environ. Sustain. 5 (1), 53-66.

Vonlanthen, P., Bittner, D., Hudson, A.G., Young, K.A., Muller, R., Lundsgaard-Hansen, B., Roy, D., Di Piazza, S., Largiader, C.R., Seehausen, O., 2012. Eutrophication causes speciation reversal in whitefish adaptive radiations. Nature 482, 357.

Waldner, P., Thimonier, A., Graf Pannatier, E., Marchetto, A., Ferretti, M., Calderisi, M., Rautio, P., Derome, K., Nieminen, T., Nevalainen, S., Lindroos, A.-J., Merilä, P., Kindermann, G., Neumann, M., Dobbertin, M., Cools, N., de Vos, B., Roskams, P., Hansen, K., Dietrich, H.-P., Fischer, R., Granke, O., Iost, S., Lorenz, M., Meining, S., Nagel, H.-D, Simoncic, P., Wilpert, K.V., Meesenburg, H., Verstraeten, A., Scheuschner, T., Ingerslev, M., Raspe, S., 2012. Forest Condition in Europe, (2012): Technical Report of ICP Forests. In: Lorenz, M., Becher, G. (Eds.), 01/2012: Chapter 5. Exceedance of Critical Limits and Their Impact on Tree Nutrition. Thünen Institute for World Forestry, pp. 77-91.

Walker, B., Carpenter, S., Anderies, J., 2002. Resilience management in socialecological systems: a working hypothesis for a participatory approach. Conserv. Ecol. 6 (1), 14.

Walker, B., Meyers, J.A., 2004. Thresholds in ecological and social-ecological systems: a developing database. Ecol. Soc. 9 (2), 3 http://www.ecologyandsociety. org/vol9/iss2/art3/.

Walker, B., Salt, D., 2012. Resilience Thinking: Sustaining Ecosystems and People in a Changing World. Island Press.

Wang, R., Dearing, J.A., Langdon, P.G., Zhang, E., Yang, X., Dakos, V., Scheffer, M., 2012. Flickering gives early warning signals of a critical transition to a eutrophic lake state. Nature 492, 419-422.

Wheatcroft, R.A., Smith, C.R., Jumars, P.A., 1989. Dynamics of surficial trace assemblages in the deep-sea. Deep-Sea Res. A 36, 71-91.

White, P.S., Jentsch, A., 2001. The search for generality in studies of disturbance and ecosystem dynamics. Progress in Botany, vol. 62. Springer, Berlin, Heidelberg, pp. 399-449.

Wiesner, C., Wolter, C., Rabitsch, W., Nehring, S., 2010. Gebietsfremde Fische in Deutschland und Österreich und mögliche Auswirkungen des Klimawandels Ergebnisse aus dem F+E-Vorhaben FKZ 80682 330. BfN-Skripten. Bundesamt für Naturschutz, $196 \mathrm{pp}$.

Willis, K.J., Bailey, R.M., Bhagwat, S.A., Birks, H.J.B., 2010. Biodiversity baselines, thresholds and resilience: testing predictions and assumptions using palaeoecological data. Trends Ecol. Evol. 25 (10), 583-591.

Zens, M., Michaelis, H., Herlyn, M., Reetz, M., 1997. Die Miesmuschelbestände der niedersächsischen Watten im Frühjahr 1994. Ber. Forschungsstelle Küste Norderney 41, 141-155.

Zeileis, A., Kleiber, C., Kramer, W., Hornik, K., 2003. Testing and dating of structural changes in practice. Comput. Stat. Data Anal. 44, 109-123.

Zeuss, D., Brandl, R., Brandle, M., Rahbek, C., Brunzel, S., 2014. Global warming favours light-coloured insects in Europe. Nat. Commun., 5

Zurlini, G., Li, B.L., Zaccarelli, N., Petrosillo, I., 2014. Spectral entropy, ecological resilience, and adaptive capacity for understanding, evaluating, and managing ecosystem stability and change. Glob. Change Biol., http://dx.doi.org/10.1111/ gcb.12707. 